\title{
Performance of secondary wastewater treatment methods for the removal of contaminants of emerging concern implicated in crop uptake and antibiotic resistance spread: A review
}

Krzeminski, Pawel; Tomei, Maria Concetta; Karaolia, Popi; Langenhoff, Alette; Almeida, C. Marisa R.; Felis, Ewa; Gritten, Fanny; Andersen, Henrik Rasmus; Fernandez, Telma; Manaia, Celia Total number of authors:

12

Published in:

Science of the Total Environment

Link to article, DOI:

10.1016/j.scitotenv.2018.08.130

Publication date:

2019

Document Version

Peer reviewed version

Link back to DTU Orbit

Citation (APA):

Krzeminski, P., Tomei, M. C., Karaolia, P., Langenhoff, A., Almeida, C. M. R., Felis, E., Gritten, F., Andersen, H. R., Fernandez, T., Manaia, C., Rizzo, L., \& Fatta-Kassinos, D. (2019). Performance of secondary wastewater treatment methods for the removal of contaminants of emerging concern implicated in crop uptake and antibiotic resistance spread: A review. Science of the Total Environment, 648, 1052-1081.

https://doi.org/10.1016/j.scitotenv.2018.08.130

\section{General rights}

Copyright and moral rights for the publications made accessible in the public portal are retained by the authors and/or other copyright owners and it is a condition of accessing publications that users recognise and abide by the legal requirements associated with these rights.

- Users may download and print one copy of any publication from the public portal for the purpose of private study or research.

- You may not further distribute the material or use it for any profit-making activity or commercial gain

- You may freely distribute the URL identifying the publication in the public portal 


\section{Accepted Manuscript}

Performance of secondary wastewater treatment methods for the removal of contaminants of emerging concern implicated in crop uptake and antibiotic resistance spread: A review

Pawel Krzeminski, Maria Concetta Tomei, Popi Karaolia, Alette Langenhoff, C. Marisa R. Almeida, Ewa Felis, Fanny Gritten, Henrik Rasmus Andersen, Telma Fernandez, Celia Manaia, Luigi

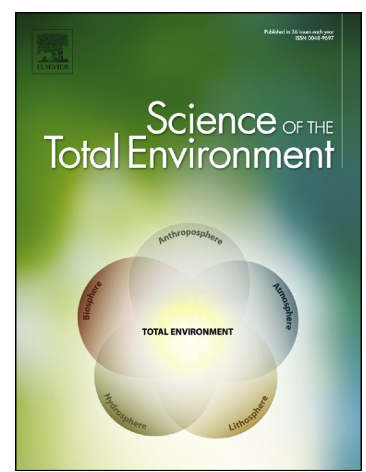
Rizzo, Despo Fatta-Kassinos

PII:

S0048-9697(18)33094-8

DOI: doi:10.1016/j.scitotenv.2018.08.130

Reference: STOTEN 28192

To appear in: Science of the Total Environment

Received date: 18 May 2018

Revised date: 9 August 2018

Accepted date:

9 August 2018

Please cite this article as: Pawel Krzeminski, Maria Concetta Tomei, Popi Karaolia, Alette Langenhoff, C. Marisa R. Almeida, Ewa Felis, Fanny Gritten, Henrik Rasmus Andersen, Telma Fernandez, Celia Manaia, Luigi Rizzo, Despo Fatta-Kassinos , Performance of secondary wastewater treatment methods for the removal of contaminants of emerging concern implicated in crop uptake and antibiotic resistance spread: A review. Stoten (2018), doi:10.1016/j.scitotenv.2018.08.130

This is a PDF file of an unedited manuscript that has been accepted for publication. As a service to our customers we are providing this early version of the manuscript. The manuscript will undergo copyediting, typesetting, and review of the resulting proof before it is published in its final form. Please note that during the production process errors may be discovered which could affect the content, and all legal disclaimers that apply to the journal pertain. 


\section{Performance of secondary wastewater treatment methods for the removal of contaminants of emerging concern implicated in crop uptake and antibiotic resistance spread: a review}

Pawel Krzeminski ${ }^{a}$, Maria Concetta Tomei ${ }^{b}{ }^{b}$, Popi Karaolia ${ }^{c}$, Alette Langenhoff ${ }^{d}$, C. Marisa R. Almeida ${ }^{\text {e }}$, Ewa Felis ${ }^{\mathrm{f}}$, Fanny Gritten ${ }^{\mathrm{g}}$, Henrik Rasmus Andersen ${ }^{\mathrm{h}}$, Telma Fernandez ${ }^{\mathrm{i}}$, Celia Manaia $^{\text {i }}$, Luigi Rizzo ${ }^{j}$, Despo Fatta-Kassinos ${ }^{c}$

${ }^{a}$ Section of Systems Engineering and Technology, Norwegian Institute for Water Research (NIVA), Gaustadalléen 21, N-0349 Oslo, Norway

${ }^{b}$ Water Research Institute, C.N.R., Via Salaria km 29.300, CP 10, 00015 Monterotondo Stazione (Rome), Italy

${ }^{c}$ Department of Civil and Environmental Engineering and Nireas-International Water Research Center, School of Engineering, University of Cyprus, P.O. Box 20537, 1678 Nicosia, Cyprus

${ }^{d}$ Sub-department of Environmental Technology, Wageningen University and Research, P.O. Box 17, 6700 AA Wageningen, The Netherlands

${ }^{e}$ CIIMAR - Interdisciplinary Centre of Marine and Environmental Research of the University of Porto, Novo Edifício do Terminal de Cruzeiros do Porto de Leixões, Avenida General Norton de Matos, S/N, 4450-208 Matosinhos, Portugal

${ }^{f}$ Environmental Biotechnology Department, Faculty of Power and Environmental Engineering, Silesian University of Technology, ul.Akademicka 2, 44-100 Gliwice, Poland

${ }^{g}$ CEBEDEAU, Research and Expertise Center for Water, Allée de la Découverte 11 (B53), Quartier Polytech 1, B-4000 Liège, Belgium

${ }^{h}$ Department of Environmental Engineering, Technical University of Denmark, Bygningstorvet 115, 2800 Kgs. Lyngby, Denmark

${ }^{i}$ Universidade Católica Portuguesa, CBQF - Centro de Biotecnologia e Química Fina - Laboratório Associado, Escola Superior de Biotecnologia, Rua Arquiteto Lobão Vital, 172, 4200-374 Porto, Portugal ${ }^{j}$ Department of Civil Engineering, University of Salerno, 84084 Fisciano (SA), Italy

* Corresponding Author (M. Concetta Tomei)

E-mail address: tomei@irsa.cnr.it 


\section{Abstract}

Contaminants of emerging concern (CEC) discharged in effluents of wastewater treatment plants (WWTPs), not specifically designed for their removal, pose serious hazards to human health and ecosystems. Their impact is of particular relevance to wastewater disposal and re-use in agricultural settings due to CEC uptake and accumulation in food crops and consequent diffusion into the foodchain. This is the reason why the chemical CEC discussed in this review have been selected considering, besides recalcitrance, frequency of detection and entity of potential hazards, their relevance for crop uptake. Antibiotic-resistant bacteria (ARB) and antibiotic resistance genes (ARGs) have been included as microbial CEC because of the potential of secondary wastewater treatment to offer conditions favourable to the survival and proliferation of ARB, and dissemination of ARGs. Given the adverse effects of chemical and microbial CEC, their removal is being considered as an additional design criterion, which highlights the necessity of upgrading conventional WWTPs with more effective technologies. In this review, the performance of currently applied biological treatment methods for secondary treatment is analysed. To this end, technological solutions including conventional activated sludge (CAS), membrane bioreactors (MBRs), moving bed biofilm reactors (MBBRs), and nature-based solutions such as constructed wetlands (CWs) are compared for the achievable removal efficiencies of the selected CEC and their potential of acting as reservoirs of ARB\&ARGs. With the aim of giving a picture of real systems, this review focuses on data from full-scale and pilot-scale plants treating real urban wastewater. To achieve an integrated assessment, technologies are compared considering also other relevant evaluation parameters such as investment and management costs, complexity of layout and management, present scale of application and need of a post-treatment. Comparison results allow the definition of design and operation strategies for the implementation of CEC removal in WWTPs, when agricultural reuse of effluents is planned. 
Keywords: secondary wastewater treatment; biological processes; CEC removal; antibiotic resistance; EU Watch list; crop uptake;

\section{Table of contents}

1. Introduction and objectives

2. Selection of CEC

3. Selection of secondary wastewater treatment technologies

3.1 Criteria for selection

3.2 Removal mechanisms of CEC for the selected treatment technologies

4. Effects of secondary treatments on chemical CEC fate

4.1 Influent characterization

4.2 Conventional activated sludge

4.3 Membrane bioreactors

4.4 Constructed Wetlands

4.5 Moving bed biofilm reactor

5. Effect of secondary treatments on microbial CEC fate

5.1 Fate of culturable antibiotic-resistant bacteria

5.2 Multi-drug resistance phenotypes

5.3 Fate of antibiotic resistance genes

5.4 Antibiotic resistance through the metagenomics lens

6. WWTPs design, operation and upgrading for CEC removal: techno-economical evaluations

6.1 Impact of CEC removal implementation on WWTPs design and operation

6.2 Feasibility of WWTPs upgrading to remove CEC

6.3 Techno-economical comparison of the selected technologies

7. Future perspectives and research needs 


\section{Introduction and objectives}

A discussion on the performance of technologies applied in wastewater treatment plants (WWTPs) for secondary treatment cannot disregard the presence of contaminants of emerging concern (CEC) in wastewaters, when assessing hazards to human health and ecosystems. According to the NORMAN network (2017), a CEC is "a substance currently not included in routine environmental monitoring programmes and may be candidate for future legislation due to its adverse effects and/or persistency”. Also, according to the United States Geological Survey (USGS) CEC include: “any synthetic or naturally occurring chemical or any microorganism that is not commonly monitored in the environment but has the potential to enter the environment and cause known or suspected adverse ecological and/or human health effects" (Klaper and Welch 2011).

Currently, there is no standardized categorization of CEC, and generally, examined categories include among others, pharmaceuticals, personal care products, plasticizers, flame retardants, and pesticides.

The release of CEC to the aquatic environment has been occurring for a long time, but suitable detection methods were not available until recently. As a result, nowadays we are able to identify and quantify these compounds. The synthesis of new chemicals, or changes in use and disposal of existing chemicals can create new sources of CEC into aquatic environments.

Abbreviations: $\mathrm{A}^{2} \mathrm{O}$, anaerobic-anoxic-oxic; ACTM, Acetamiprid; ARB, antibiotic resistant bacteria; ARGs, antibiotic resistance genes; AZM, Azithromycin; BDL, below detection limit; BHT, 2,6-Ditert-butyl-4-methylphenol; BOD, biochemical oxygen demand; BTA, Benzotriazole; CAS, conventional activated sludge; CBZ, Carbamazepine; CEC, contaminants of emerging concern; CIP, Ciprofloxacin; COD, chemical oxygen demand; CW, constructed wetland; Da, dalton; DCF, Diclofenac; DO, dissolved oxygen; DOC, dissolved organic carbon; E1, Estrone; E2, 17-Beta-estradiol; EE2, 17-Alpha-ethynylestradiol; EDG, electron donating functional groups; EHMC, 2-Ethylhexyl 4-methoxycinnamate; ENR, Enrofloxacin; ERY, Erythromycin; EWG, electron withdrawing functional groups; EU, European Union; F/M, Food to microorganisms ratio; HBCD, Hexabromocyclododecane; HGT, horizontal gene transfer; HRT, hydraulic retention time; IntI1, class 1 integron; $\mathrm{K}_{\text {biol }}$, kinetic reaction rate constant, $\mathrm{L} / \mathrm{g}_{\mathrm{ss}} \cdot \mathrm{d}$; $\mathrm{K}_{\mathrm{d}}$, solid-water partition coefficient, $\mathrm{L} / \mathrm{kg}_{\mathrm{Ss}} ; \mathrm{K}_{\mathrm{ow}}$, octanol-water partition coefficient; LCA, life cycle assessment; MBBR, moving bed biofilm reactor; MBR, membrane bioreactor; MDR, multi-drug resistance; MF, microfiltration; MLSS, mixed liquor suspended solids; MLVSS, mixed liquor volatile 
suspended solids; MRSA, methicillin-resistant Staphylococcus aureus; N.A., not available; NDMA, N-Nitrosodimethylamine; NEREUS, COST Action ES1403 'New and emerging challenges and opportunities in wastewater reuse'; NORMAN, Network of reference laboratories, research centres and related organisations for monitoring of emerging environmental substances; NSAID, nonsteroidal anti-inflammatory compound; PCPs, personal care products; PE, population equivalent; PFBA, Perfluorobutanoic acid; PFHxA, Perfluorohexanoic acid; PFPeA, Perfluoropentanoic acid; QMRA, quantitative microbial risk assessment; q-PCR, quantitative polymerase chain reaction; SF CW, surface flow CWs; SMX, Sulfamethoxazole; SRT, sludge retention time; SWWTP, small WWTP of < 5.000 PE; TBBPA, Tetrabromobisphenol A; TCS, Triclosan; TCEP, Tris(2-chloroethyl)phosphate; TMP, Trimethoprim; TPs, transformation products; TSS, total suspended solids; UF, ultrafiltration; USGS, United States Geological Survey; VRE, Vancomycinresistant enterococci; WWTP, wastewater treatment plant.

In addition to the occurrence of chemical CEC in water environments, the widespread use and misuse of antibiotic residues and their uncontrolled emission in the environment was shown to contribute to the proliferation of antibiotic resistant bacteria (ARB) and their associated genes (antibiotic resistance genes, ARGs) (Berendonk et al., 2015), whose presence has been also detected in urban wastewater (Michael et al., 2013; Rizzo et al., 2013; Li et al., 2014a; Berglund et al., 2015; Xu et al., 2015). In this review, the latter are considered as microbial CEC. WWTPs can potentially reduce the emission of CEC including antibiotics. However, they also represent an important emission source of CEC to the receiving water bodies, due to the incomplete removal of a large number of these compounds. Moreover, WWTPs can act as collection points for ARB and antimicrobials from a variety of sources (i.e., hospitals, industries, households), consequently becoming point sources for environmental dissemination of antibiotic resistance (Pruden et al., 2013).

The above-mentioned aspects give an idea of the complexity of the issues arising from the presence of CEC in aquatic environments and antibiotic resistance-related problems. A wide spectrum of chemical and microbial contaminants with different physicochemical properties, toxicological characteristics and degree of potential risk must be managed, requiring suitable responses according to the applied treatment process. WWTPs are only partially effective in CEC removal or degradation, so these residual CEC are discharged into the environment with treated effluent and excess sludge. In 
an era of water scarcity, the presence of residual amounts of CEC in treated effluents is not only a problem for the environment but can also compromise treated wastewater reuse.

The fate of CEC highly depends on the type of treatment applied at a specific WWTP. There are many factors determining the removal of specific classes of contaminants in WWTPs: compound chemical properties, plant configuration, hydraulic retention time (HRT), operating conditions (i.e. $\mathrm{pH}$, temperature, etc), presence of industrial wastewater, etc. Furthermore, WWTPs commonly need to operate on a broad and heterogeneous group of contaminants in a wide range of influent concentrations (varying from 0.001 to $1000 \mu \mathrm{g} / \mathrm{L}$ ) [based on Table 2 data]. Therefore, there is a need for technological solutions effective for various contaminants and under different operating conditions.

The CEC have attracted the attention of the scientific community in the recent years, with many review papers addressing various aspects of CEC. These reviews were either focused on selected pharmaceutical compounds such as diclofenac, estrogens or antibiotics (Rivera-Utrilla et al., 2013; Vieno and Sillanpää 2014; Polesel et al., 2016; Schröder et al., 2016; Tiedeken et al., 2017) or on the selected treatment processes applied for CEC removal. Among these processes, membrane-based processes (Siegrist and Joss 2012; de Cazes et al., 2014; Li et al., 2015; Ojajuni et al., 2015; Shojaee Nasirabadi et al., 2016; Taheran et al., 2016; Kim et al., 2018), constructed wetlands (CWs) (Dordio and Carvalho 2013; Li et al., 2014b; Verlicchi and Zambello 2014; Zhang et al., 2014; Gorito et al., 2017), biological processes such as conventional activated sludge (CAS), membrane bioreactors (MBRs), and bioelectrochemical systems (Verlicchi et al., 2012; Rojas et al., 2013; Vieno and Sillanpää 2014; Besha et al., 2017; Cecconet et al., 2017; Grandclément et al., 2017; Tiwari et al., 2017), and various conventional and advanced processes such as advanced oxidation processes (AOPs) or activated carbon (Rivera-Utrilla et al., 2013; Luo et al., 2014; Barbosa et al., 2016; Bui et al., 2016; Hamza et al., 2016; Ahmed et al., 2017; Rodriguez-Narvaez et al., 2017; Tiedeken et al., 2017; Yang et al., 2017) were reviewed. In addition, aspects such as the use of hybrid systems 
(Grandclément et al., 2017), impact on membrane fouling (Besha et al., 2017) sorption and biotransformation (Alvarino et al., 2018), geographical distribution (Tran et al., 2018), and comprehensive strategies for managing CEC (Talib and Randhir 2017) were also reviewed.

The gaps that have been identified in these reviews were, among others, related to the significance and reliability of the collected CEC removal data being based on synthetic wastewater, small labscale systems, specific industrial wastewaters and/or unsuitable sampling (Taheran et al. 2016, Cecconet et al. 2017, Grandclément et al. 2017, Tran et al. 2018). In addition, the need of a costbenefit evaluation of the different treatment technologies (Bui et al. 2016, Grandclément et al. 2017) and the lack of information on design for optimum performance (Ahmed et al. 2017) were also pointed out. Furthermore, the general lack of knowledge on the occurrence of CEC in WWTP effluents and on the efficiency of different treatment methods (Schröder et al. 2016) as well as the need for intensification of technology-focused studies for effective and efficient control measures of CEC (Tiedeken et al. 2017), have been reported. One of the processes listed was a biofilm process, such as the moving bed biofilm reactor (MBBR) (Tran et al. 2018). Finally, due to the increasing importance of wastewater reuse as well as to the concern for antibiotic resistance spread from WWTPs effluents, there is a clear need to review the microbial CEC, namely ARB\&ARGs and relevant aspects related to crop uptake.

To this end, the aim of this review is to address these gaps and specifically: i) to give a picture of real applications by focusing on full-scale systems, ii) to analyse the performance of currently applied secondary biological treatment technologies (namely CAS, MBR and MBBR) and nature-based solutions (namely CWs) for the removal of CEC, iii) to summarize current knowledge on the occurrence of antibiotic resistance after biological treatment and on the potential for antibiotic resistance spread, and iv) to combine present findings on technical and economic considerations regarding the compared technologies as an attempt to provide input for a cost-benefit evaluation. Thus, the novelty of this paper predominantly lies in reviewing only full- and pilot-scale plants 
treating real urban wastewater, and including microbial CEC and crop uptake aspects, which are of relevance for wastewater reuse. Therefore, the performance of the investigated technologies is analysed for a group of target CEC relevant for wastewater reuse, including the compounds reported in the EU Watch list (Decision 2015/495/EU, (2015/495/EU) and others, which are relevant for crop uptake (Piña et al. 2018). This last factor is essential for reuse, because the CEC present in the treated wastewater that is used for irrigation, can accumulate in food crops, being the first link for CEC diffusion into the human food-chain, consequently being of relevance given the unintentional human exposure. The prevalence of antibiotic resistance after biological treatment is also analysed to search for common trends regions on WWTPs potential for antibiotic resistance spreading, in spite of variables that may influence the outcomes, e.g. the operating conditions, plant configuration or geographic regions.

\section{Selection of CEC}

A list of $33 \mathrm{CEC}$ was compiled for investigation in the present review: compounds were selected according to their relevance to wastewater reuse, in particular for potential uptake by crops, public health issues and/or environmental safety implications. In addition to this list of organic microcontaminants, also ARB\&ARGs were included as CEC, an option that is justified by the critical relevance of these (micro)biological contaminants to public health and, above all, the recognized persistence and self-replication potential of these micro-contaminants in environmental compartments. The selection of specific organic and microbial CEC was based on the recommendations of the NEREUS COST Action ES $1403^{1}$, a network of scientists and stakeholders interested in urban wastewater reuse from 42 countries. The NEREUS COST Action Working Group 2 activities, focused on 'Uptake and translocation of organic micro-contaminants and ARB\&ARGs in crops' identified and indicated compounds relevant to crop uptake. This list was combined with a

\footnotetext{
${ }^{1}$ COST Action ES1403 New and emerging challenges and opportunities in wastewater reuse (NEREUS), http://www.nereus-cost.eu
} 
list of compounds from the EU Watch List, recommended by the NEREUS COST Action Working Group 4, whose activities focused on 'Technologies efficient/economically viable to meet the current wastewater reuse challenges', due to their environmental and health relevant aspects.

The following criteria reported in order of priority, were taken into account during the selection of the CEC for examination in this review.

i. Uptake by crops. Once in the agricultural environment, CEC have the potential to be taken up by fodder and edible crops. The uptake of pharmaceuticals has been demonstrated by various authors (Calderón-Preciado et al., 2013; Goldstein et al., 2014; Malchi et al., 2014; Christou et al., 2017; Christou et al., 2018). More specifically in a study by Calderón-Preciado et al., (2013), the uptake of various CEC and metabolites by lettuce, carrots, potatoes, tomatoes, cucumbers and green beans irrigated with reclaimed water has been examined. The results of these studies showed that non-ionic pharmaceuticals such as carbamazepine are taken up at higher concentrations compared to ionic compounds, by the examined plants. Moreover, the presence of carbamazepine metabolites in the leaves of carrots and potatoes at higher concentrations than the parent compound, suggests the occurrence of uptake and metabolic breakdown of carbamazepine inside the crop plants.

ii. Effects on crop production. Plant exposure to CEC may affect plant development, either through direct contact and damage, or as the result of the action of pharmaceuticals on plant microbiota and soil microorganisms, so having a role in plant-microorganism symbioses and soil nutrient cycling (Peñuelas et al., 2013). Ferrari et al., (2003) investigated the effect of carbamazepine, diclofenac and clofibric acid residues found in irrigated wastewater on the microalga Pseudokirchinella subcapitata, demonstrating a reduction in growth in the algal nutrient solution in the presence of the CEC, at a concentration of $10 \mathrm{mg} / \mathrm{L}$. In another study by Eggen et al., (2011), the effect of the uptake of metformin, ciprofloxacin and narasin (an anti-coccidial) in carrot and barley were investigated. The results showed negative effects on the growth of all plants investigated, when these were grown in soil, which contained a concentration of these CEC at 6 to $10 \mathrm{mg} \mathrm{kg}^{-1}$ dry weight. 
iii. Environmental- and human-health concern. The occurrence of CEC in environmental compartments has been often associated to a number of biological adverse effects, such as toxic effects, endocrine disruption and antibiotic resistance in microorganisms (Luo et al., 2014). Yet, the potential effects of CEC remain unclear and in need of further investigations (Ahmed et al., 2017). In 2015, the European Commission established the EU Watch List (Decision (2015/495/EU) of 17 substances for monitoring in water. Their inclusion has been justified by their potential to cause damage to aquatic environments and to pose a significant risk at European Union level, but for which monitoring data are insufficient to come to a conclusion regarding the actual posed risk. These compounds belong to various categories such as estrogenic hormones, non-steroidal antiinflammatory compounds (NSAIDs), antibiotics, UV filters and antioxidant compounds, pesticides and herbicides.

iv.Recalcitrance. Recalcitrant compounds, which remain practically unaltered during wastewater treatment, require special attention, as they may accumulate in environments receiving treated wastewater, and may thus pose a hazard to environmental health. For instance, Jones et al., (2017) investigated recently the fate of 95 CEC in 3 full-scale WWTPs after trickling filter treatment followed by nitrification, or after activated sludge treatment. Their results indicated that a group of compounds were recalcitrant to both treatments, as their removal varied from $-58 \%$ to $14 \%$. Azithromycin (total average removal of 14\%), carbamazepine (1\%) and estrone (13\%) were among the recalcitrant CEC. Moreover, the antibiotic erythromycin was found to be recalcitrant during biological treatment according to various studies conducted in real wastewater effluents (Yang et al., 2011; Guerra et al., 2014; Kim et al., 2014; Pasquini et al., 2014), indicating the importance of antibiotic monitoring in treated effluent receiving environments.

v.Frequency of detection. Frequency of detection is an indicator of persistence and tolerance to biological treatment. For example, compounds like sulfamethoxazole, carbamazepine, diclofenac, estrone and estradiol showed high frequency of detection being present in all treated wastewater 
samples $(n=16)$ of four WWTPs in southern California (Vidal- Dorsch et al., 2012). Loos et al., (2013) found similar results in an EU-wide monitoring survey assessing the occurrence of polar chemical contaminants in effluents of 90 WWTPs. Carbamazepine and ciprofloxacin showed a frequency of $90 \%$, and sulfamethoxazole and diclofenac were detected with a frequency of 83 and 89\% respectively. Metformin and benzotriazole were also detected in high concentrations exceeding $1 \mu \mathrm{g} / \mathrm{L}$ in the effluent during the screening of the Swiss WWTPs (Margot et al., 2013).

The list of the compounds examined in this review, based on the above selection criteria, is shown in Table 1. 
Table 1. Properties, function of selected compounds and justification of their selection for the purposes of this review.

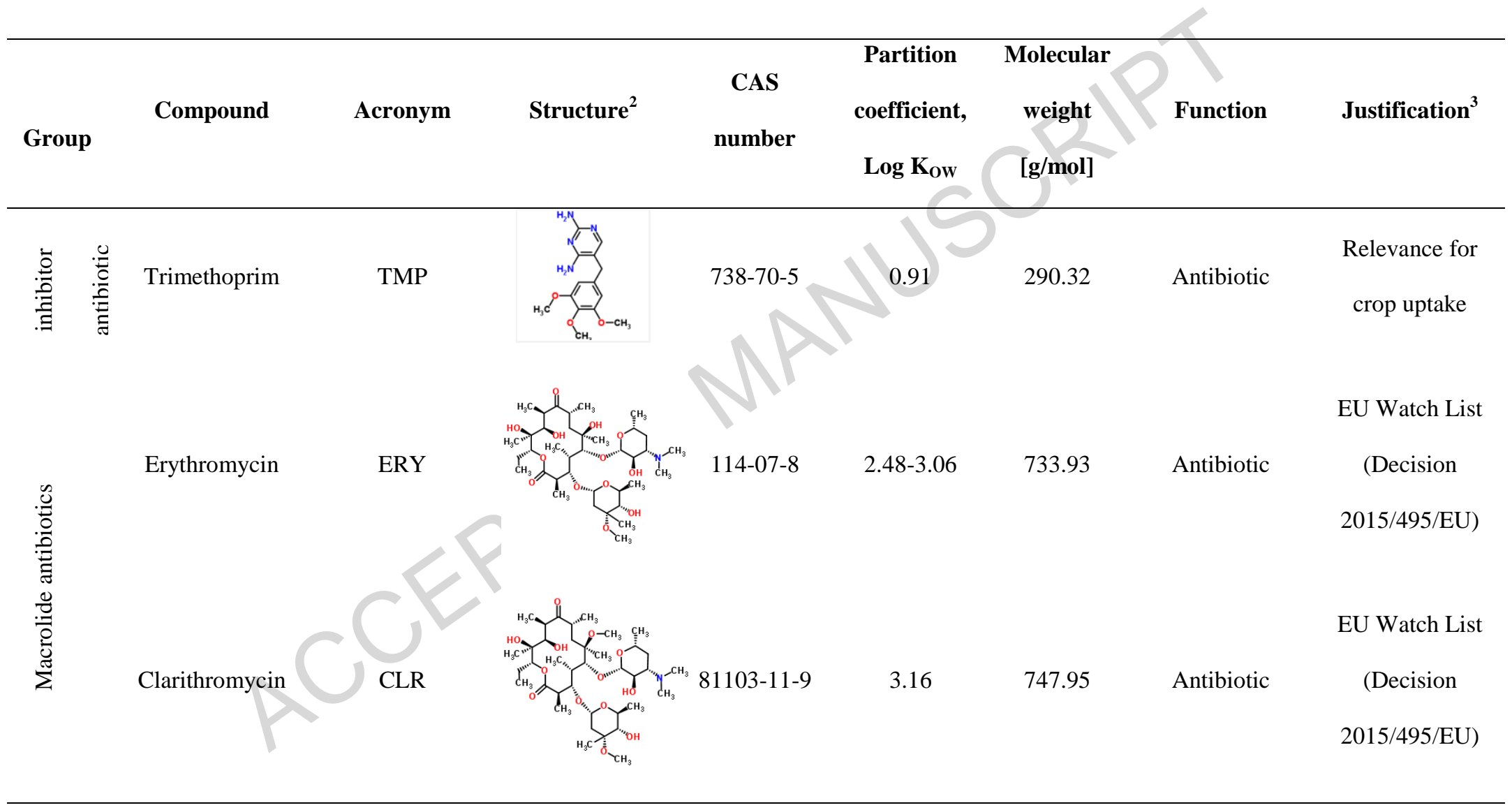

\footnotetext{
2 http://www.chemspider.com

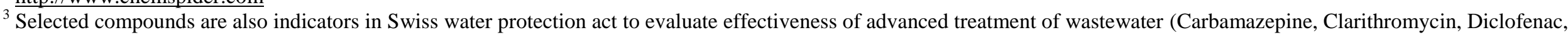
Benzotriazole) or listed as priority hazardous substance in Norway (TCEP, TBBPA, HBCD, Triclosan).
} 


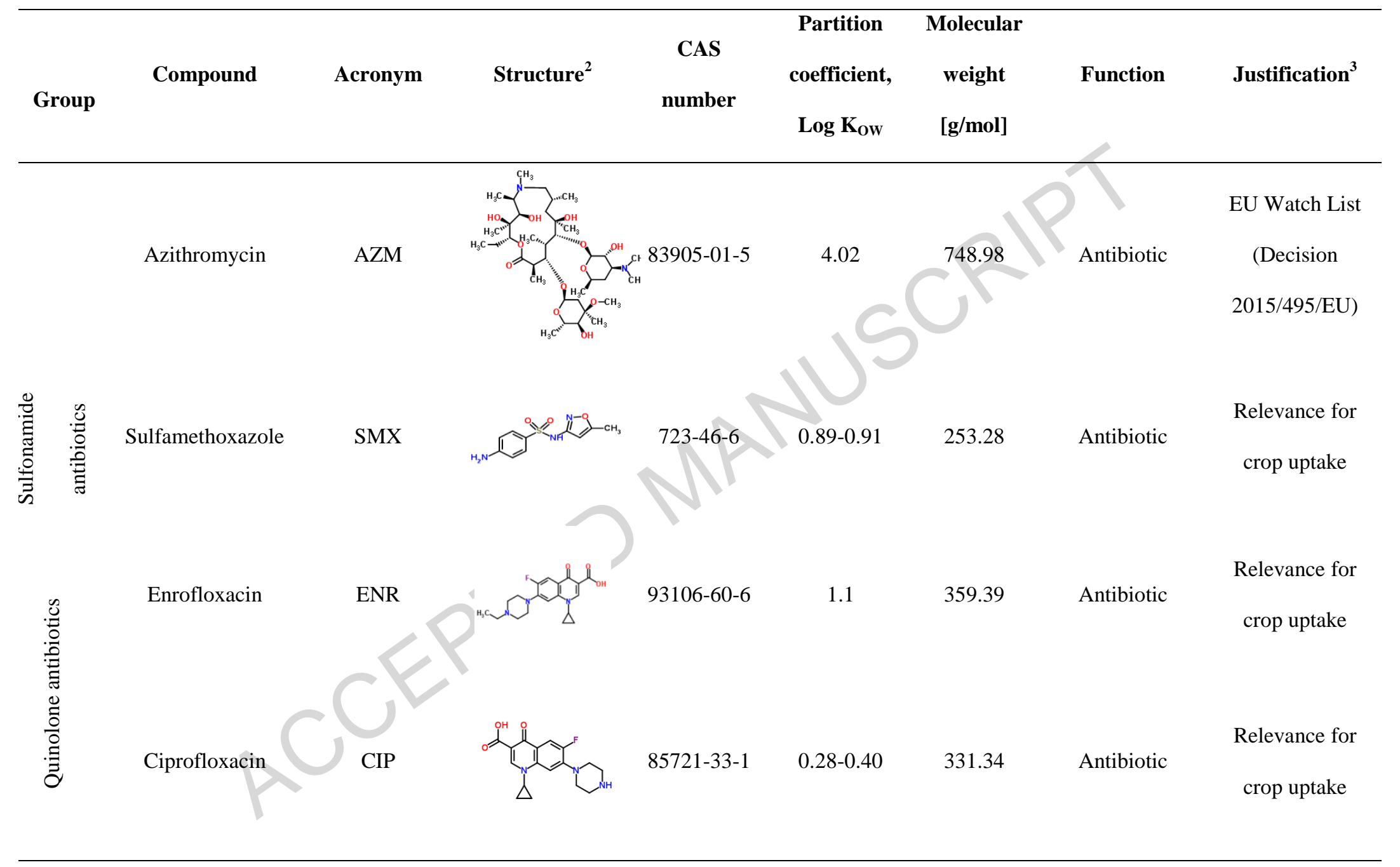




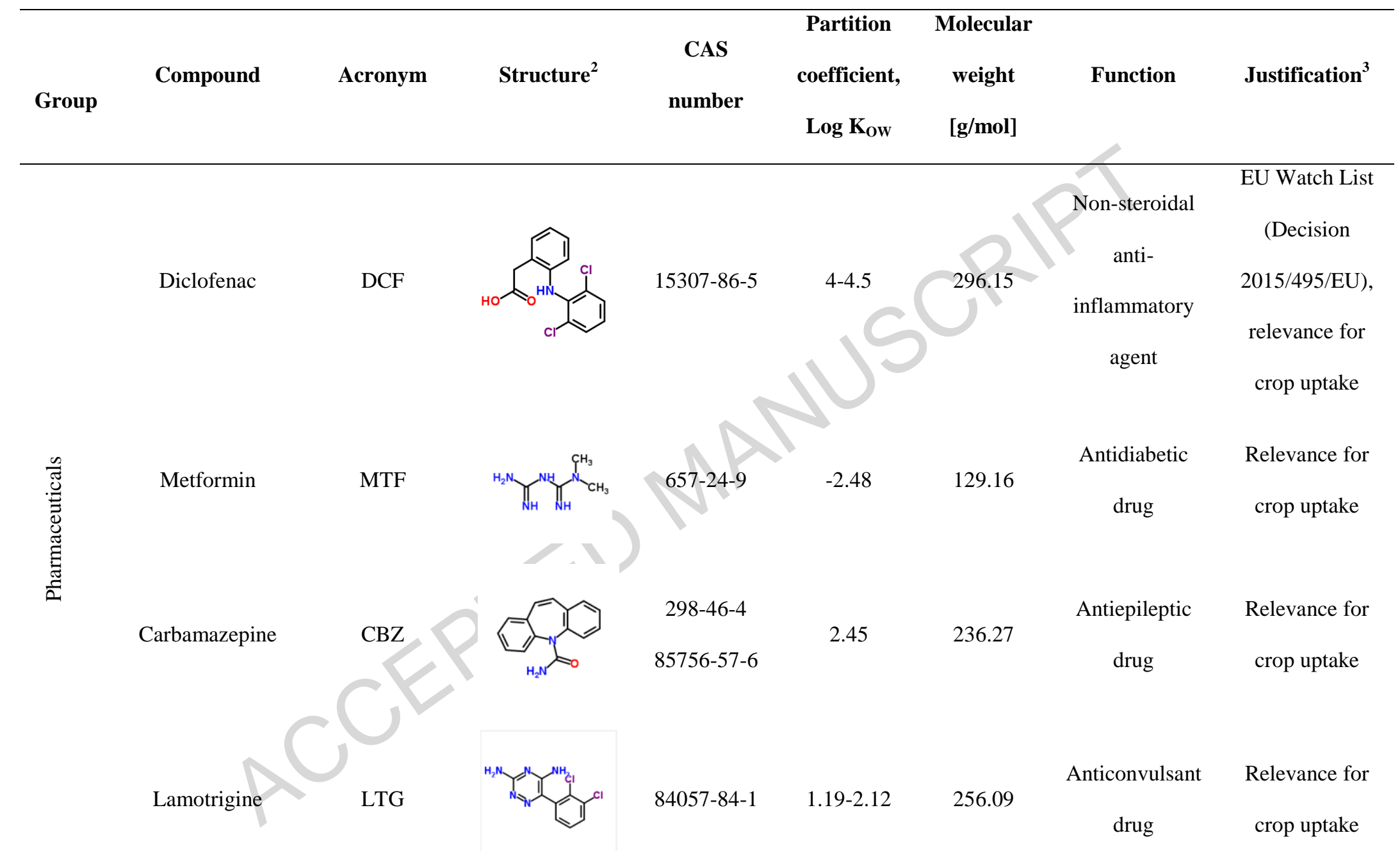




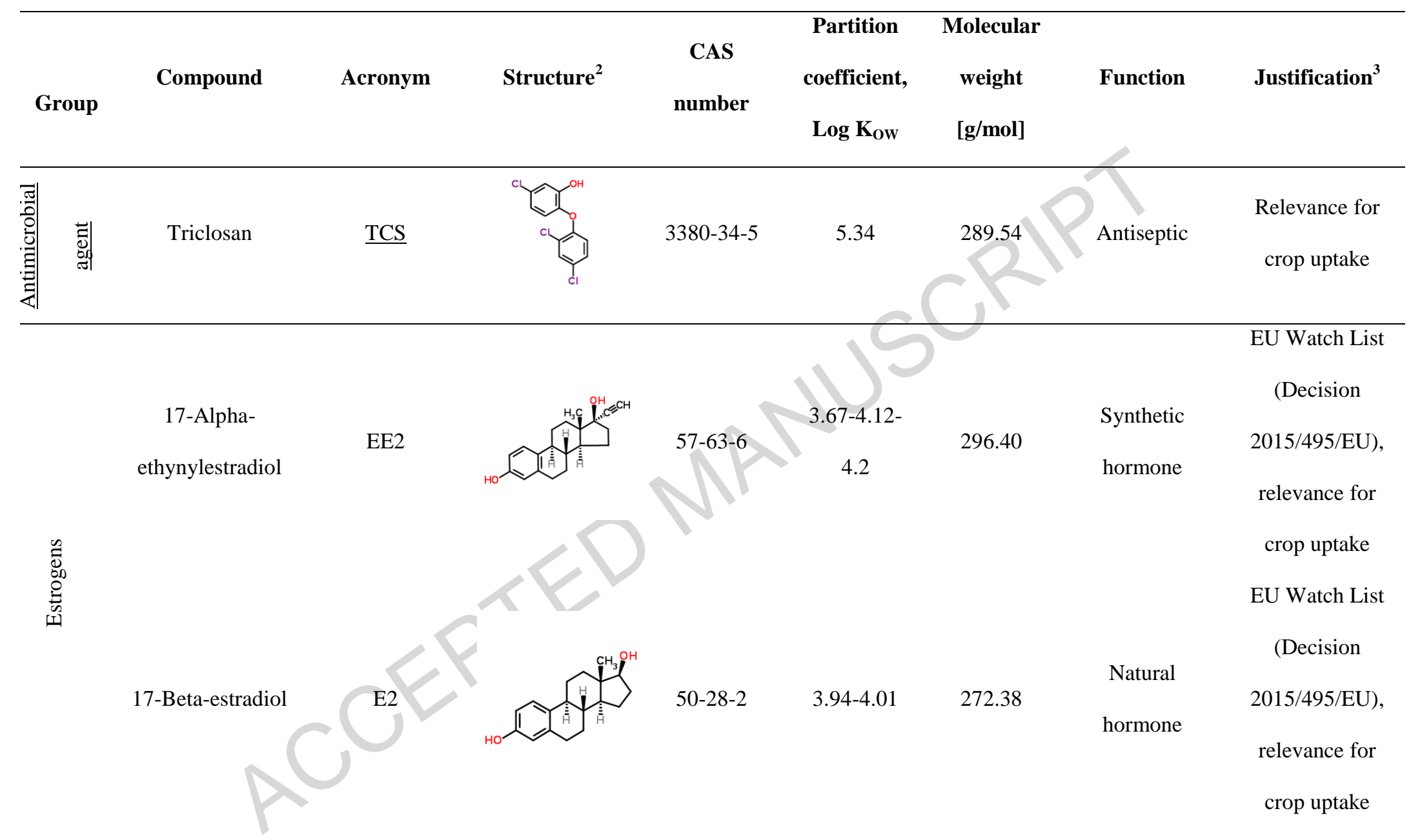




\begin{tabular}{|c|c|c|c|c|c|c|c|c|}
\hline Group & Compound & Acronym & Structure $^{2}$ & $\begin{array}{c}\text { CAS } \\
\text { number }\end{array}$ & $\begin{array}{l}\text { Partition } \\
\text { coefficient, } \\
\text { Log } K_{\text {OW }}\end{array}$ & $\begin{array}{l}\text { Molecular } \\
\text { weight } \\
\text { [g/mol] }\end{array}$ & Function & Justification $^{3}$ \\
\hline & Estrone & E1 & & $53-16-7$ & $.13-3.43$ & & $\begin{array}{l}\text { Natural } \\
\text { hormone } \\
\text { (breakdown } \\
\text { product of E2) }\end{array}$ & $\begin{array}{l}\text { EU Watch List } \\
\text { (Decision } \\
\text { 2015/495/EU) }\end{array}$ \\
\hline & $\begin{array}{c}\text { 2,6-Ditert-butyl-4- } \\
\text { methylphenol }\end{array}$ & BHT & & & $3.5-5.1$ & 220.35 & $\begin{array}{l}\text { Antioxidant } \\
\text { (food additive) }\end{array}$ & $\begin{array}{l}\text { EU Watch List } \\
\text { (Decision } \\
\text { 2015/495/EU) }\end{array}$ \\
\hline 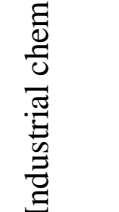 & $\begin{array}{l}\text { chloroethyl)phosp } \\
\text { hate }\end{array}$ & $\mathrm{CF}$ & & $115-96-8$ & $1.44-1.6$ & 285.49 & $\begin{array}{c}\text { Flame retardant, } \\
\text { plasticizer }\end{array}$ & $\begin{array}{l}\text { Relevance for } \\
\text { crop uptake }\end{array}$ \\
\hline & $\begin{array}{c}\text { Tetrabromobisphe } \\
\text { nol A }\end{array}$ & & & $79-94-7$ & $5.3-5.9$ & 543.87 & $\begin{array}{l}\text { Brominated } \\
\text { flame retardant }\end{array}$ & $\begin{array}{l}\text { Relevance for } \\
\text { crop uptake }\end{array}$ \\
\hline
\end{tabular}




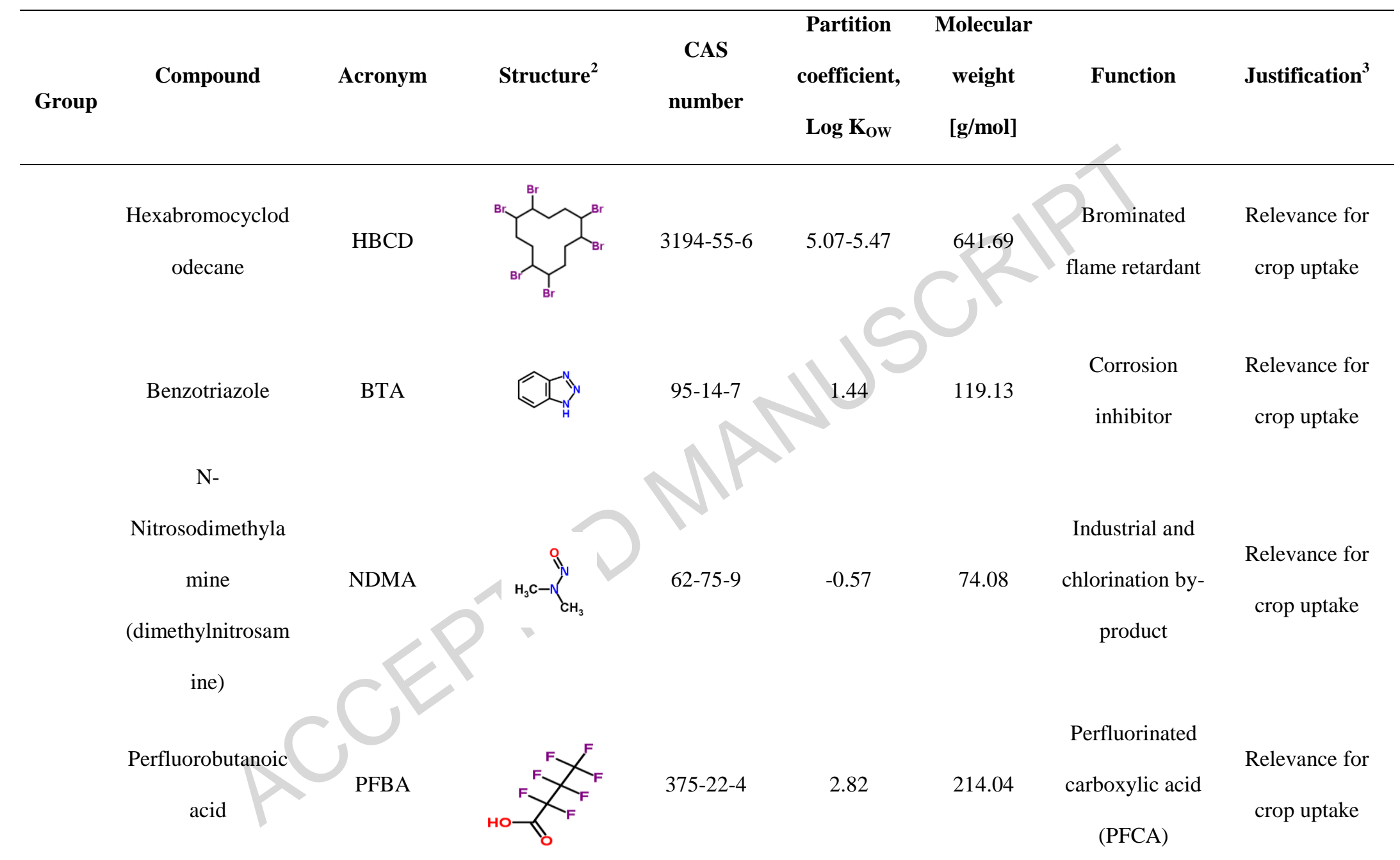




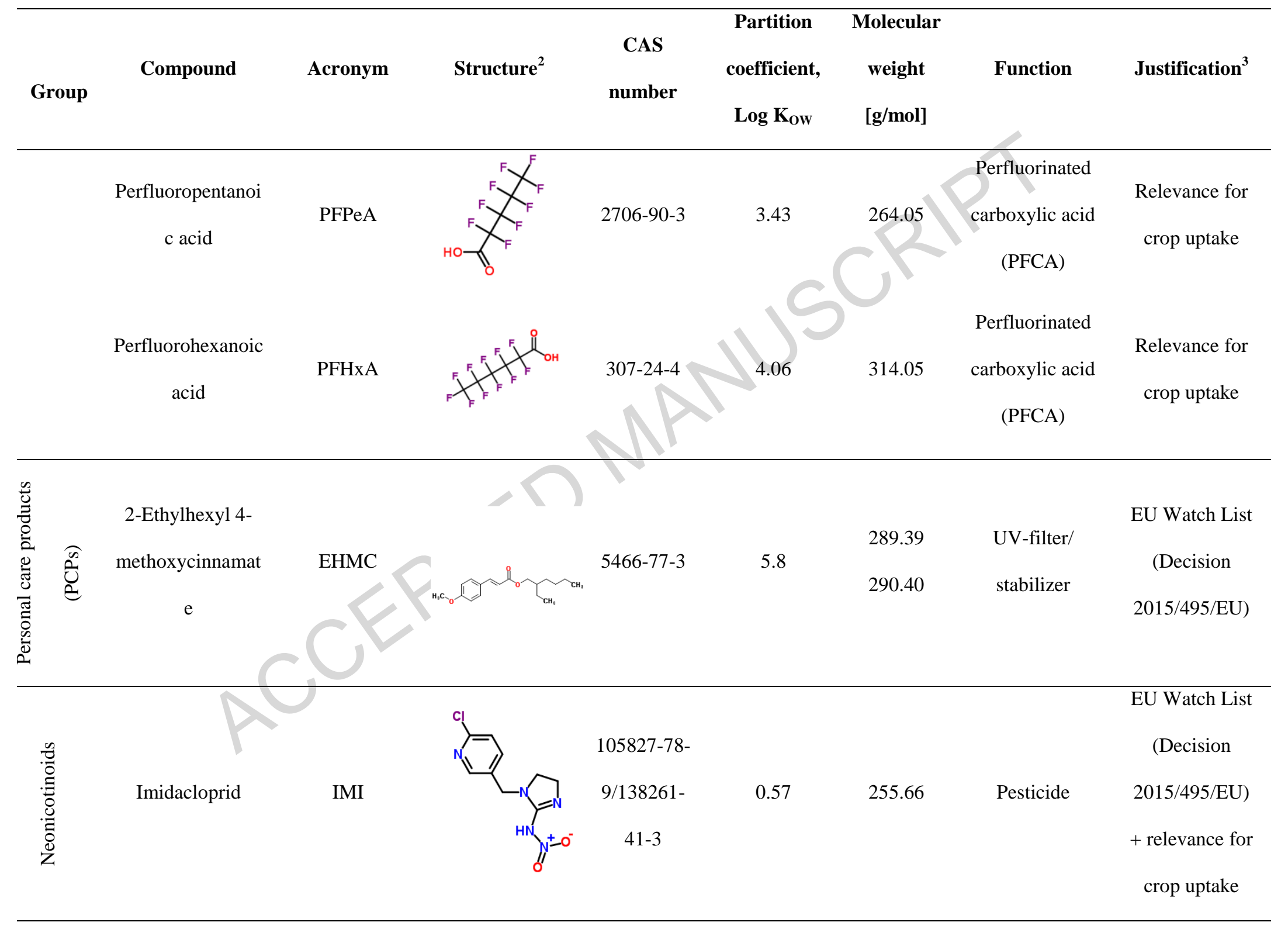




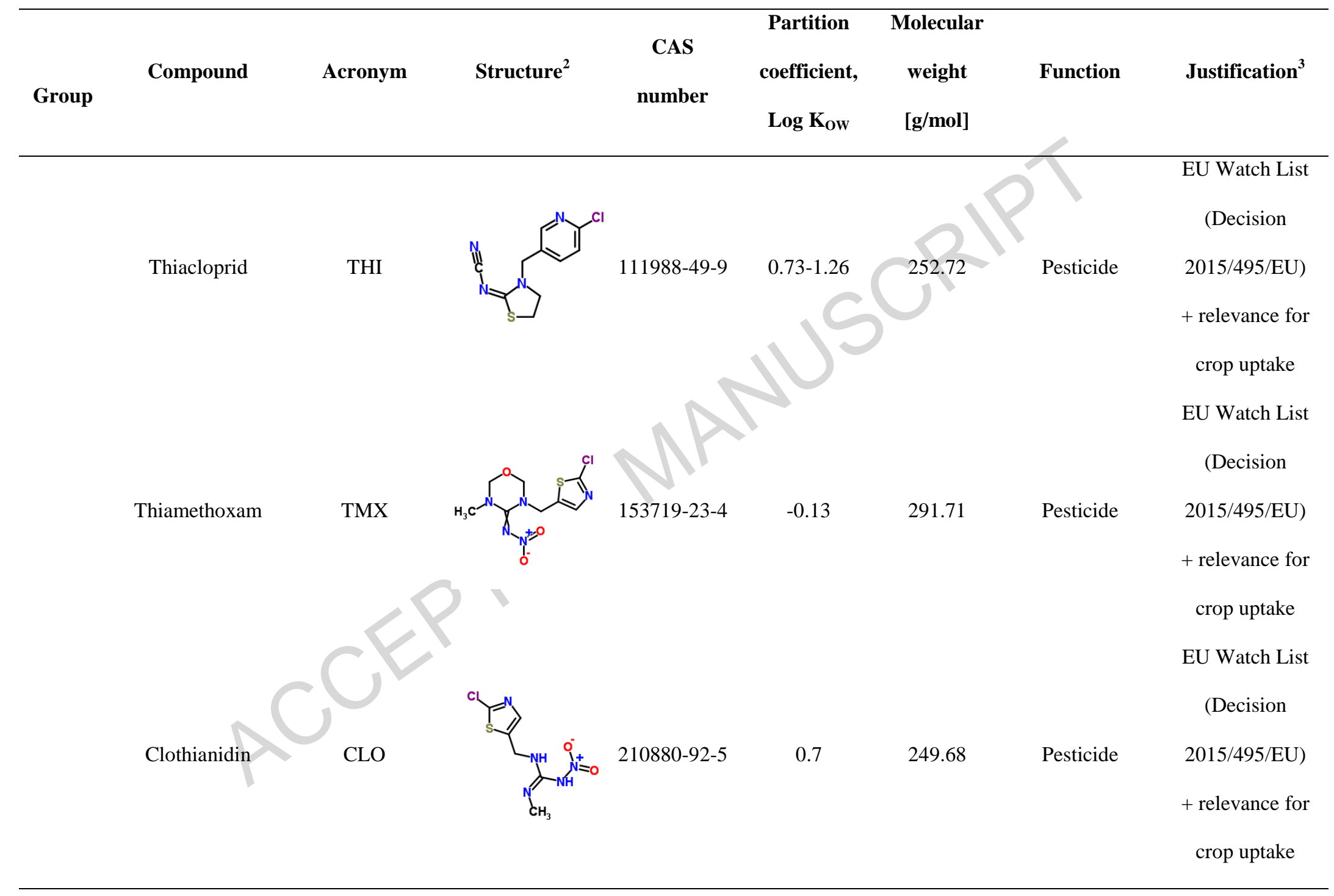




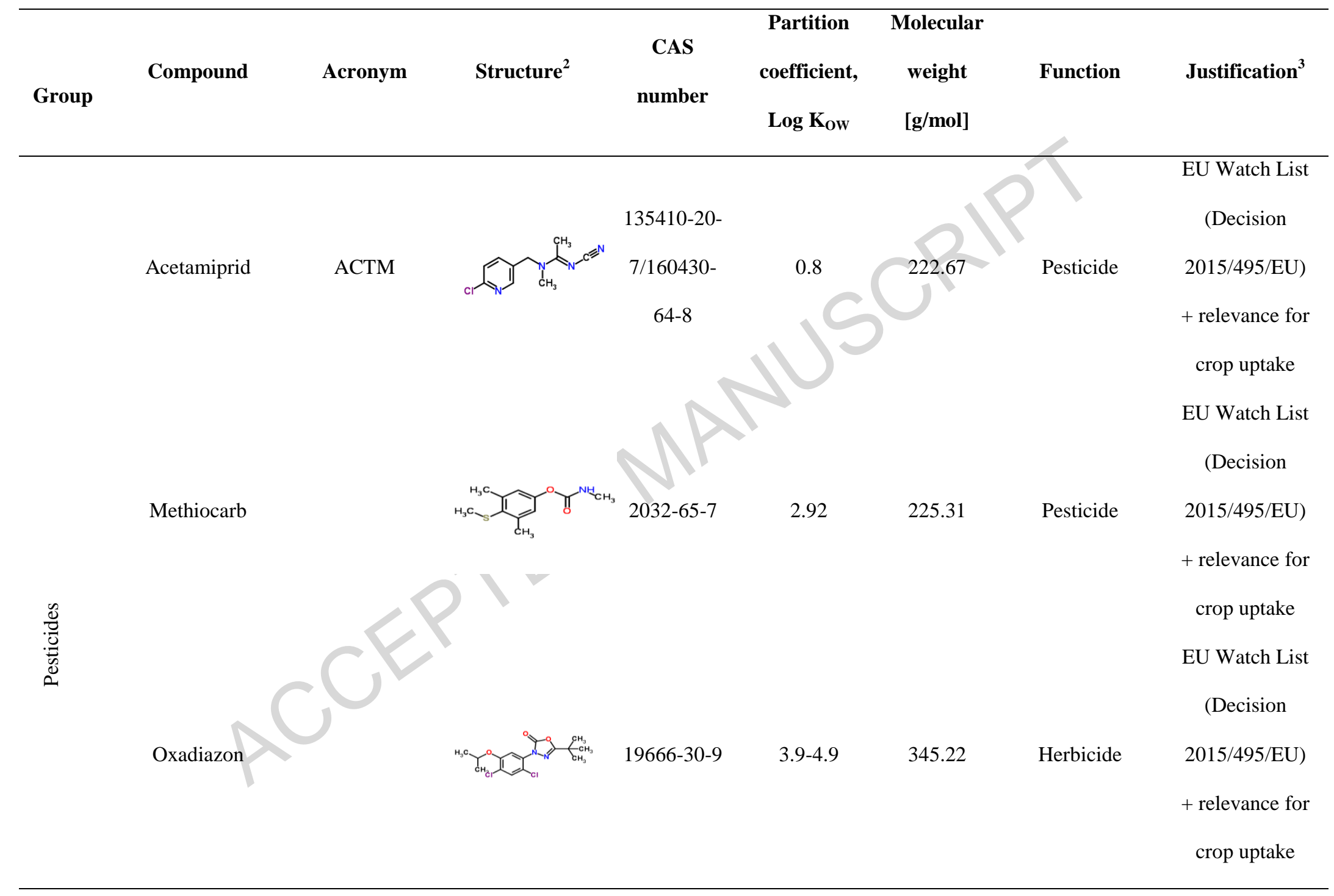




\begin{tabular}{|c|c|c|c|c|c|c|c|c|}
\hline Group & Compound & Acronym & Structure $^{2}$ & $\begin{array}{c}\text { CAS } \\
\text { number }\end{array}$ & $\begin{array}{l}\text { Partition } \\
\text { coefficient, } \\
\text { Log } K_{O W}\end{array}$ & $\begin{array}{c}\text { Molecular } \\
\text { weight } \\
\text { [g/mol] }\end{array}$ & Function & Justification $^{3}$ \\
\hline & Triallate & & & $2303-17-5$ & 4.6 & & Herbicide & $\begin{array}{c}\text { EU Watch List } \\
\text { (Decision } \\
\text { 2015/495/EU) } \\
+ \text { relevance for } \\
\text { crop uptake }\end{array}$ \\
\hline
\end{tabular}




\section{Selection of secondary wastewater treatment technologies}

\subsection{Criteria for selection}

The examined technologies applied in secondary wastewater treatment were selected according to their present level of application at full scale WWTPs, as well as to the state of knowledge of their performance for the removal of the selected CEC. The availability of reliable dataset for CEC was mandatory to this aim and, unfortunately, not so many data are available for technologies other than CAS and MBRs. Accordingly, the attention was mainly focused on these two treatment options. However, MBBRs, a potentially effective technology for CEC removal, and CWs, as a valid example of nature-based method characterized by easy installation and operation as well as good removal efficiencies for several CEC, were also introduced as potential promising alternatives to CAS and MBRs.

\subsection{Removal mechanisms of CEC for the selected treatment technologies}

For the CAS process, the main removal mechanisms of CEC are biodegradation (intended as complete mineralization of the compound) and sorption. Their occurrence and extent depend on the operating parameters of the plants i.e. SRT, Food to Microorganisms (F/M) ratio, presence of aerated and not aerated zones, $\mathrm{pH}$ and temperature. Previous studies found that long SRT have a positive effect on the removal of several compounds (Cirja et al., 2017), in particular on hormones and antibiotics, which are mainly removed by biodegradation (Strenn et al., 2004). This removal increase may be justified by the fact that long SRTs may promote growth of slow growing bacteria with various enzymes, which have been shown to have positive effects on removal of various CEC including diclofenac, erythromycin and 17 $\alpha$-ethynylestradiol (Suarez et al., 2010; FernandezFontaina et al., 2012). In addition, varying composition of the solid matrix and different sorption capacities due to high SRTs in conjunction with reduced F/M ratio may also increase microbial 
diversity (Göbel et al., 2007). The influence of HRT has been a subject of discussion as it was reported to enhance some compounds degradation (Metcalfe et al., 2003; Gros et al., 2010) as well as to have negligible effect on removal of other compounds, e.g. diclofenac (Bernhard et al., 2006). Moreover, high biomass concentrations provide higher stability, persistence to shock loads, increased contact between microorganisms and pollutants, thus facilitating their biodegradation (Cirja et al., 2007; Verlicchi et al., 2012; Trinh et al., 2016a). This may also induce microorganisms metabolism of poorly degradable compounds due to relative shortages in biodegradable substances associated with reduced F/M ratio (Verlicchi et al., 2012). Suarez et al., (2010) classified CEC based on the removal potential under different biological conditions: i) highly removed under aerobic and anoxic conditions (e.g., ibuprofen, fluoxetine, natural estrogens); ii) highly removed under aerobic but persistent under anoxic conditions (e.g., diclofenac, 17 $\alpha$-ethynylestradiol, erythromycin), and iii) refractory to biological transformation (e.g., sulfamethoxazole, carbamazepine). Finally, temperature of wastewater as well as seasonal temperature changes play a role in the removal of CEC, as better removal is obtained at temperatures of $15-20^{\circ} \mathrm{C}$ compared to below $10^{\circ} \mathrm{C}$ (Vieno et al., 2005; Castiglioni et al., 2006).

Biodegradation and sorption are also the main CEC removal mechanisms in MBRs (Radjenović et al., 2008; Verlicchi et al., 2012; Luo et al., 2014; Li et al., 2015). This is because of the low molecular size of most CEC, typically below 1000 dalton, which leads to no direct physical retention on MF (microfiltration) and UF (ultrafiltration) membranes (retention size of ca. 10 000-500 000 Da). However, the sludge deposits formed on the membrane surface can act as an additional barrier contributing to the removal of CEC ( $\mathrm{Li}$ et al., 2015). Furthermore, the hydrophobicity of CEC influences CEC sorption and removal. The removal is improved when the compound is significantly hydrophobic $\left(\log \mathrm{K}_{\mathrm{ow}}>3\right)$, such as the case of diclofenac, EE2, E2, EHMC, azithromycin, triallate and oxadiazon (Phan et al., 2014). Otherwise, sorption onto biosolids is limited and biodegradation is 
the dominant removal mechanism. Variable removal efficiencies have been reported in MBRs for persistent compounds, including diclofenac and carbamazepine, which have low $\mathrm{k}_{\text {biol }}$ and low $\mathrm{K}_{\mathrm{d}}$ values (Wijekoon et al., 2013). Despite the agreement on the higher removal of hydrophobic compounds and containing electron donating functional groups (EDG) compared to the compounds with opposite characteristics by MBRs, there is still a lack of understanding on the complete causes of removal of CEC and their transformation products (TPs) in MBRs (Reif et al., 2013). Concerning the effect of the operating parameters on CEC removal in MBRs, similarly to CAS, Li et al., (2015) concluded that higher SRT, lower $\mathrm{pH}$, higher nitrogen loading rate, and anoxic conditions favour removal of some pharmaceutical micropollutants in MBRs.

In CWs, a combination of physical, chemical, and biological processes may occur simultaneously and contribute to CEC removal. These include photodegradation, volatilization, phytoremediation, adsorption and sedimentation, as well as microbial biodegradation (Matamoros et al., 2005; HijosaValsero et al., 2010a; Reyes-Contreras et al., 2012; Li et al., 2014b). First, photodegradation is an important removal pathway for CEC in CW systems with free water surface, i.e. surface flow CWs (Andreozzi et al., 2003). Seasonal variations leading to lower light availability, lower light intensity, or stronger light attenuation with increasing water depth will reduce photodegradation efficiency in aquatic systems (Buser et al., 1998; Matamoros et al., 2008). These parameters will also affect removal of compounds with high volatilization potential. Secondly, the plants in CWs can directly uptake and translocate CEC (Dordio et al., 2009; Dordio et al., 2010; Hijosa-Valsero et al., 2010b; Hijosa-Valsero et al., 2011a; Carvalho et al., 2014). This uptake and translocation is most likely driven by diffusion, as no specific transporters exist within plants to move CEC into plant tissues (Dordio and Carvalho 2013). In addition, CEC can be transformed to less toxic compounds during metabolization in plants (Salt et al., 1998; He et al., 2017). Furthermore, the substrate of a CW (the CWs filling) can support growth of microorganisms and plants, and can adsorb different compounds, 
including CEC. Substrates with a greater adsorption capability for CEC can significantly enhance CEC removal (Dordio et al., 2007; Bui and Choi 2010; Conkle et al., 2010).

In MBBRs, the main removal mechanism is biodegradation. The amount of CEC eliminated with excess sludge withdrawal is lower than with CAS system as MBBRs work at a very low organic load. As mentioned in the CAS section above, SRT is as an important operational parameter for the removal of several micropollutants (Strenn et al., 2004). The agglomeration of bacteria as a biofilm and the retention of the support media for the attached growth process in the biological reactor results in long SRT. The geometry of the support media for bacterial growth allows the development of thin $(\sim 50 \mu \mathrm{m})$ or thick $(>200 \mu \mathrm{m})$ biofilms with different density, biodiversity composition, microbial activity and redox conditions (Torresi et al., 2017). Thin biofilms result in high nitrifying activities (enhancement of biotransformation kinetic of diclofenac, sulfamethoxazole, erythromycin, atenolol) while thick biofilms have a high bacterial biodiversity (more than $60 \%$ of target compounds showed higher biotransformation kinetics). Thus, combining the more suitable media and operational conditions lead the MBBR process to enhance specific or overall CEC elimination.

\section{Effects of secondary treatments on chemical CEC fate}

\subsection{Influent characterization}

To evaluate the performance of the analyzed technologies it is important to have information on the CEC concentrations present in WWTPs influents. These concentrations are relevant for the determination of the efficiency of the applied technology. Data available for the selected compounds are reported in supplementary material Table SM1, while the range of concentrations is reported in Table 2. A variable range, from a few $\mathrm{ng} / \mathrm{L}$ to several $\mu \mathrm{g} / \mathrm{L}$, is observed, which makes necessary to evaluate, case by case, the effluent quality and the related CEC emissions. 
Table 2. Concentration range of the selected CEC in municipal wastewater before treatment.

\begin{tabular}{|c|c|c|}
\hline Category & $\begin{array}{l}\text { Concentration } \\
\text { range (ng/L) }\end{array}$ & Reference \\
\hline \multicolumn{3}{|l|}{ Antibiotics } \\
\hline Trimethoprim & $13-6000$ & $\begin{array}{l}\text { (Gobel et al., 2005; Perez et al., 2005; Leung et al., 2012; Senta et al., } \\
\text { 2013; Guerra et al., 2014; Carvalho and Santos 2016; Botero-Coy et } \\
\text { al., 2018) }\end{array}$ \\
\hline Erythromycin & $17-320$ & $\begin{array}{l}\text { (Yang and Carlson 2004; Gobel et al., 2005; Gros et al., 2006; } \\
\text { Papageorgiou et al., 2016; Botero-Coy et al., 2018) }\end{array}$ \\
\hline Clarithromycin & BDL-8000 & $\begin{array}{l}\text { (Loganathan et al., 2009; Margot et al., 2013; Birošová et al., 2014; } \\
\text { Guerra et al., 2014; Tran et al., 2018) }\end{array}$ \\
\hline Azithromycin & BDL-6810 & $\begin{array}{l}\text { (Gobel et al., 2005; Loganathan et al., 2009; Margot et al., 2013; } \\
\text { Senta et al., 2013; Botero-Coy et al., 2018) }\end{array}$ \\
\hline Sulfamethoxazole & BDL-3100 & $\begin{array}{l}\text { (Gobel et al., 2005; Perez et al., 2005; Gros et al., 2006; Margot et al., } \\
\text { 2013; Zhou et al., 2013; Guerra et al., 2014; Papageorgiou et al., }\end{array}$ \\
\hline Enrofloxacin & $3-100$ & Tatkinson et al., 2007; Ghosh et al., 2009; Birošová et al., 2014) \\
\hline Ciprofloxacin & $15-3350$ & $\begin{array}{l}\text { (Watkinson et al., 2007; Margot et al., 2013; Zhou et al., 2013; He et } \\
\text { al., 2015; Botero-Coy et al., 2018) }\end{array}$ \\
\hline
\end{tabular}

\section{Other pharmaceuticals/antimicrobials}

Diclofenac

Metformin

Metformin

Carbamazepine

Lamotrigine

Triclosan
(Clara et al., 2005b; Gros et al., 2006; Margot et al., 2013; Sari et al., 2014)

BDL->10000 ～(Margot et al., 2013; Kosma et al., 2015)

$54-1850$

(Clara et al., 2005b; Nakada et al., 2006; Margot et al., 2013)

$13-1110$

500- 6100
(Bollmann et al., 2016; Zonja et al., 2016)

(Lindstrom et al., 2002; Singer et al., 2002; Halden and Paull 2005;

Ying and Kookana 2007) 


\section{Industrial Chemicals}

2,6-Ditert-butyl-

4-methylphenol(BHT)

Tris(2-chloroethyl)

180-439

phosphate (TCEP)

Tetrabromobisphenol A

Hexabromocyclododecane

(HBCD)

Benzotriazole (BTA)

N-Nitrosodimethylamine

(dimethyl-nitrosamine)

Perfluorobutanoic acid

$0.05-265$

(PFBA)

Perfluoropentanoic acid

(PFPeA)

Perfluorohexanoic acid

$1-348$

(PFHxA)

$183-8230$

$0.5-1520$
1119- 44000

(Lin et al., 2010; Ma and Shih 2010; Pan et al., 2011; Kim et al., 2012; Zhang et al., 2013; Zhang et al., 2015a)

(Lin et al., 2010; Ma and Shih 2010; Kim et al., 2012; Zhang et al.,

2013; Zhang et al., 2015a)

\section{Estrogens}

\begin{tabular}{lcl}
\hline Estrone (E1) & $11.6-224$ & (Zhou et al., 2012; Margot et al., 2013; Ekpeghere et al., 2018) \\
$17 \beta$-Estradiol (E2) & $3.7-140$ & (Zhou et al., 2012; Margot et al., 2013; Ekpeghere et al., 2018) \\
$17 \alpha$-Ethynylestradiol (EE2) & BDL-330 & (Zhou et al., 2012; Margot et al., 2013; Ekpeghere et al., 2018)
\end{tabular}

\section{Personal care products}

2-Ethylhexyl 23-1290 (Tsui et al., 2014; Ekpeghere et al., 2016)

ethoxycinnamate (EHMC)

\section{Neonicotinoids}

\begin{tabular}{lll}
\hline Imidacloprid & 54.7 & (Sadaria et al., 2016) \\
Thiacloprid & BDL & (Sadaria et al., 2016)
\end{tabular}




\begin{tabular}{lll}
\hline Thiamethoxam & BDL & (Sadaria et al., 2016) \\
Clothianidin & 149.7 & (Sadaria et al., 2016) \\
Acetamiprid & 3.7 & (Sadaria et al., 2016) \\
\hline Pesticides & & \\
\hline Methiocarb & N.A. & \\
Oxadiazon & N.A. & \\
Triallate & N.A. & \\
\hline
\end{tabular}

Legend: BDL - below detection limit; N.A. - not available.

\subsection{Conventional activated sludge}

Data available on the removal efficiencies detected for CAS are mainly related to pharmaceuticals (by far the most investigated class of CEC), personal care products and endocrine disruptor compounds.

The high concentrations especially for some pharmaceuticals reported in Table 2 show that, even when high removal efficiencies are achieved, consistent residual amounts will remain in the effluent which can significantly impact the receiving water body or compromise treated wastewater reuse.

Table 3 shows an overview of the data on the removal efficiencies for the selected CEC in secondary treatment by CAS. Reported data are mainly referring to the last decade. A high variability in the removal efficiencies is observed, which can be explained with the seasonal variation of the plant performance and the variability of the CEC influent concentrations. Moreover, the presence of very low concentrations, which, in some cases, are close or below detection limits, makes the evaluation of a precise removal efficiency difficult. A more detailed and extended table (Table SM2) on the removal efficiencies is included in supplementary material.

According to the results of a Canadian survey of 18 WWTPs (Metcalfe et al., 2003), primary treatment resulted in minimal reductions of CEC, while better results were observed for the 
secondary. It is worth noting that in several cases negative removals were observed, which are indicative of formation of parent compounds e.g., through de-conjugation, or accumulation of the substances during treatment, especially if sampling was carried out during non-steady-state plant operation. In addition, effluent quality can be worsened by the formation of intermediate products in case of partial biodegradation.

Among the selected pharmaceuticals, the neutral drug carbamazepine was poorly removed by the secondary treatment. It resulted as one of the most critical compounds, among the monitored pharmaceuticals, in all countries. This behaviour may be due to its hydrophilic nature $\left(\log \mathrm{K}_{\mathrm{ow}}<3\right)$ and chemical stability (Nakada et al., 2006). Similar behaviour is observed for lamotrigine which, in two recent studies (Bollmann et al., 2016; Zonja et al., 2016), showed a consistent concentration increase in the effluent.

For the selected antibiotics, highest removal efficiencies were detected for ciprofloxacin and sulfamethoxazole, while the other antibiotics are characterized by quite low removals.

As regard as the estrogenic compounds, higher removal efficiencies were observed for the hormone 17ß-estradiol than for estrone (Zhou et al., 2012). Secondary treatment can reach removal efficiencies $\geq 90 \%$ for estrogenic compounds but only in WWTPs performing nitrification or nitrogen removal (Andersen et al., 2003). This is because high HRT and SRT are required for efficient estrone removal, as it is confirmed by Margot et al., (2013) reporting the data of the Lausanne plant (operated without nitrification) where the removal of $17 \beta$-estradiol and estrone was $91 \%$ and $58 \pm 31 \%$, respectively.

Not many data are available for EHMC removal and neonicotinoids in CAS. Tsui et al., (2014) for a WWTP operated with Modified Ludzack Ettinger configuration, reported low to moderate removal of EHMC, i.e., $30 \%$ in the wet season and $55 \%$ in the dry season, which was negatively affected by seasonal variation of the influent load and temperature during the wet season. As regard as 
neonicotinoids, Sadaria et al., (2016) in a recent study on a WWTP measured low removal efficiencies of $11-18 \%$ for the selected compounds except for thiacloprid and thiamethoxam showing negligible concentration (BDL) in the influent and effluent.

Pesticides are among the organic contaminants most investigated in the aquatic environment, but their occurrence and fate in WWTPs has been rarely investigated, perhaps because these compounds are of agricultural rather than of urban origin. In spite of this, wastewaters represent one of the main routes of pesticide contamination into the environment (Cahill et al., 2011) and several sources justifying the presence of pesticides in WWTPs were identified. They are extensively applied in grass-maintenance, in industrial vegetation control for electric utilities, roadways, railroads, pipelines, and in non-agricultural crops such as commercial forestry and horticulture (Barceló D 2003). For these reasons, to our best knowledge data on these specific compounds in the target list are not available in literature. In any case, it is worth noting that the reported removals of pesticides in full-scale WWTPs are generally poor with presence, in some cases, of increased concentrations in the effluent (Kock-Schulmeyer et al., 2013).

An extremely variable behaviour in WWTPs is observed for industrial chemicals with almost complete/good removal for instance for BHT, TBBP-A, BTA, and wide range of removal efficiency for other compounds such as PFCAs (PFBA, PFPeA, PFHxA) and NDMA. This finding is expected if we consider the diversity of the chemical structure, which as pointed out in the paragraph 4.1 consistently affects the removal mechanisms.

From the data analysis of CAS, we can conclude that CEC removal efficiency is strongly affected by HRT and SRT. To give a general idea of the limit values, according to Metcalfe et al., (2003), worst performance is observed in plants having $\mathrm{HRT} \leq 7 \mathrm{hr}$ and $\mathrm{SRT} \leq 1.9 \mathrm{~d}$. 
Table 3. Range of the removal efficiencies of the selected CEC in CAS plants

\begin{tabular}{lll}
\hline Category & $\begin{array}{l}\text { Removal } \\
\text { efficiency (\%) }\end{array}$ & Reference \\
\hline Antibiotics & 31 & (Gobel et al., 2005) \\
\hline Trimethoprim & $(-14)-100$ & (Yang and Carlson 2004; Gobel et al., 2005; Gros et al., 2006) \\
Erythromycin & 37 & (Margot et al., 2013) \\
Clarithromycin & $11-44$ & (Gobel et al., 2005; Loganathan et al., 2009; Margot et al., 2013) \\
Azithromycin & $35-84$ & (Gobel et al., 2005; Margot et al., 2013; Zhou et al., 2013) \\
Sulfamethoxazole & $\sim 0$ & (Watkinson et al., 2007) \\
Enrofloxacin & $63-90$ & (Margot et al., 2013; Zhou et al., 2013) \\
Ciprofloxacin &
\end{tabular}

\section{Other pharmaceuticals/antimicrobials}

\begin{tabular}{lll}
\hline Diclofenac & \multicolumn{1}{c}{$\begin{array}{l}\text { (Clara et al., 2005b; Margot et al., 2013; Luo et al., 2014; Sari et } \\
\text { al., 2014) }\end{array}$} \\
Metformin & (Kosma et al., 2015) \\
Carbamazepine & (Metcalfe et al., 2003; Clara et al., 2005b; Nakada et al., 2006; \\
Lamotrigine & $(-90)-(-3)$ & Margot et al., 2013) \\
Triclosan & (Bollmann et al., 2016; Zonja et al., 2016) \\
& (Lindstrom et al., 2002; Singer et al., 2002; Halden and Paull 2005; \\
& Ying and Kookana 2007)
\end{tabular}

\section{Industrial Chemicals}

2,6-Ditert-butyl-4- 
Tris(2-chloroethyl)

$(-106)-0$

phosphate (TCEP)

Tetrabromobisphenol A 10-100

Hexabromocyclododecane 0-86

$(H B C D)$

Benzotriazole (BTA)

30-91

$5-84$

N-Nitrosodimethylamine

(dimethyl-nitrosamine)*

(NDMA)

Perfluorobutanoic acid

$(-108)-65$

(PFBA)

Perfluoropentanoic acid

(PFPeA)

Perfluorohexanoic acid

$(P F H x A)$
(Meyer and Bester 2004; Ryu et al., 2014; Zeng et al., 2015;

Cristale et al., 2016)

(Potvin et al., 2012; Kim et al., 2016)

(Vieno and Toivikko 2014; De Guzman 2016)

(Reemtsma et al., 2010; Liu et al., 2012; Asimakopoulos et al., 2013)

(Yoon et al., 2011; Wang L. 2014)

(Zhang et al., 2013; Zhang et al., 2015a)

(Pan et al., 2011; Kim et al., 2012; Zhang et al., 2013; Zhang et al., 2015a)

(Kim et al., 2012; Zhang et al., 2013; Zhang et al., 2015a)

\section{Estrogens}

\begin{tabular}{lll}
\hline Estrone (E1) & $58-81$ & (Zhou et al., 2012; Margot et al., 2013) \\
$17 \beta$-Estradiol (E2) & $91-96$ & (Zhou et al., 2012; Margot et al., 2013) \\
$17 \alpha$-Ethynylestradiol & $>18-94$ & (Zhou et al., 2012; Margot et al., 2013)
\end{tabular}

(EE2)

\section{Personal care products}

2-Ethylhexyl 30-55 (Tsui et al., 2014)

ethoxycinnamate (EHMC) 


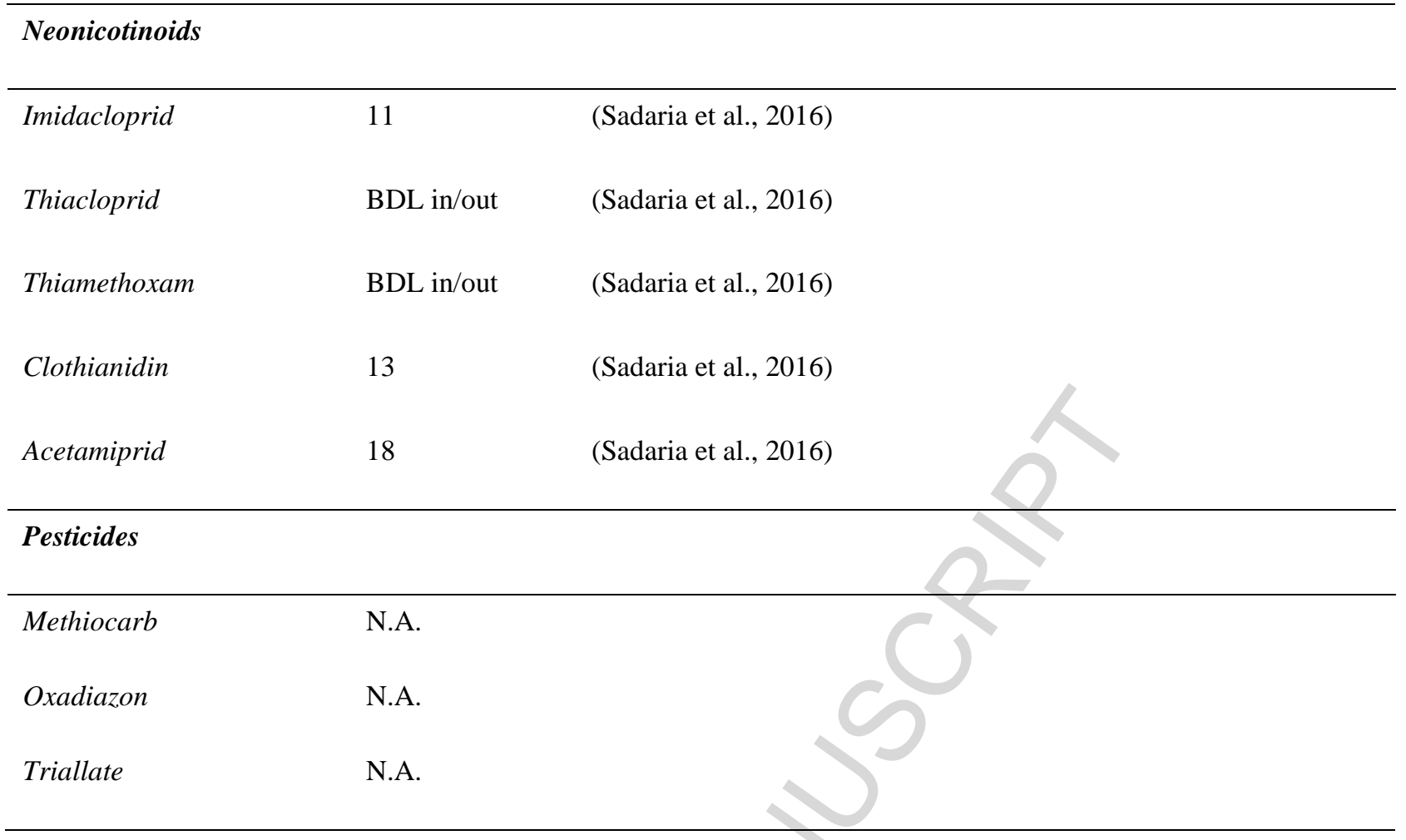

\subsection{Membrane bioreactors}

The MBR is a process that integrates biodegradation of contaminants by activated sludge, with direct solid-liquid separation by membrane filtration, i.e. through a MF or UF membrane. The MBR technology is currently widely accepted as an alternative key technology to CAS treatment utilised in urban WWTPs and water reuse applications. The wide use of MBRs has been attributed to its notable advantages, such as high quality of produced water, high biodegradation efficiency of contaminants, and an overall smaller footprint (Judd, 2015).

This technology permits bioreactor operation with considerably higher mixed liquor suspended solids (MLSS) concentration than CAS systems, which are limited by sludge settling phenomena. The process in MBRs is typically operated at MLSS in the range of 8-12 $\mathrm{g} / \mathrm{L}$, while CAS is operated in the range of 2-3 g/L (Melin et al. 2006), thus providing high biological activity per unit volume. This feature favours the generation of slow-growing bacteria, which have the ability to degrade 
certain biologically-recalcitrant organic and inorganic pollutants (Clouzot et al., 2011). Therefore, despite not been designed to remove organic and inorganic micropollutants, MBRs may provide effective removal of some of the CEC. Early studies reported improved CEC removal with MBRs compared to CAS, as MBRs operate at a higher SRT than CAS, thus enhancing contaminant biodegradability (Holbrook et al., 2002; Stephenson et al., 2007). However, when MBRs and CAS were compared under similar operating conditions (i.e., SRT, temperature) in the removal of CEC, no significant differences were observed (Joss et al., 2006; Bouju et al.m 2008; Weiss and Reemtsma, 2008; Abegglen et al., 2009). Therefore, it was postulated that MBRs and CAS systems may perform similar as long as the same operating conditions are provided, although MBRs may outperform CAS at higher SRT. This is because CEC are generally highly soluble and relatively small compounds, typically below 1000 Dalton, which can freely pass through the membranes used in MBR systems thereby indicating that those membranes have no direct impact on the removal of CEC (Snyder et al., 2007). Others report that MBRs are able to effectively remove a wide spectrum of CEC including compounds that are not eliminated during CAS processes (Radjenović et al., 2009; Luo et al., 2014).

Overall, the potential to achieve slightly improved removal of CEC in MBRs compared to the CAS process, is attributed to: (1) complete retention of suspended and colloidal particles to which many of the CEC sorb or are entrapped at the cake layer developed on the membrane surface; (2) ability to operate under longer SRT providing additional biological transformation of CEC (via diversification of microorganisms metabolic activity in response to the lower sludge loading with bulk organics) and more diversified microbial community (e.g. nitrifying bacteria); and (3) higher biomass concentrations providing higher degradation rate. All of the aforementioned factors may provide additional removal mechanisms of CEC. On the other hand, the advantage of operating MBRs at very high SRT to promote the biodegradation of recalcitrant compounds is usually offset by the 
increased operating costs associated with the higher oxygen requirements of biomass. Hence, despite significant research attention in the past years, general consensus regarding the MBRs and CAS potential to remove CEC has not been reached yet.

Table 4 summarizes the removal efficiency of the selected CEC (Hernando et al., 2007; Onesios et al., 2008; Petrovic et al., 2009; Tambosi et al., 2010b; Verlicchi et al., 2012; Reif et al., 2013; Rojas et al., 2013; de Cazes et al., 2014; Luo et al., 2014; Eggen and Vogelsang 2015; Li et al., 2015). The overview excludes the experimental work carried out using lab-scale MBR systems fed with synthetic wastewater, and reports only results from full-scale MBRs or pilot-scale MBRs located at the premises of the WWTPs and fed with real wastewater. Until now, only a limited number of the studies were performed on full-scale MBR installations (Sui et al., 2011; Trinh et al., 2012b; Oosterhuis et al., 2013; Fenu et al., 2015; Trinh et al., 2016b).

A more detailed table including the operating conditions of the WWTPs and on the type of wastewater and sampling methods is reported in the supplementary material section (Table SM3).

Table 4. Range of the removal efficiencies of the selected CEC in MBRs

\begin{tabular}{ll}
\hline Category & References \\
& $\begin{array}{l}\text { Removal } \\
\text { Antibiency (\%) }\end{array}$ \\
\hline Trimethoprim & (Göbel et al., 2007; Kim et al., 2007; Snyder et al., 2007; Tambosi et al., \\
& 2010a; Sahar et al., 2011a; Sahar et al., 2011b; Sahar et al., 2011c; Sui et \\
& al., 2011; Schröder et al., 2012; Trinh et al., 2012b; Qi et al., 2015; \\
& Arriaga et al., 2016; Tran et al., 2016; Trinh et al., 2016b; Arola et al., \\
& 2017; Park et al., 2017) \\
& (Kim et al., 2007; Radjenovic et al., 2007; Snyder et al., 2007; Barceló et \\
& al., 2009; Radjenovic et al., 2009; Xue et al., 2010; Sahar et al., 2011a;
\end{tabular}


Clarithromycin

Azithromycin

Sulfamethoxazole

$0-90$
Sahar et al., 2011b; Sahar et al., 2011c; Dolar et al., 2012; Malpei et al., 2012; Kim et al., 2014; Qi et al., 2015; Arriaga et al., 2016; Mamo et al., 2016; Tran et al., 2016)

(Göbel et al., 2007; Sahar et al., 2011a; Sahar et al., 2011b; Sahar et al., 2011c; Dolar et al., 2012; Malpei et al., 2012; Kim et al., 2014; Qi et al., 2015; Arriaga et al., 2016; Mamo et al., 2016; Tran et al., 2016; Park et al., 2017)

(Göbel et al., 2007; Dolar et al., 2012; Kim et al., 2014; Mamo et al., 2016; Tran et al., 2016)

(Kreuzinger et al., 2004; Clara et al., 2005b; Joss et al., 2005; Göbel et al., 2007; Kim et al., 2007; Radjenovic et al., 2007; Barceló et al., 2009;

Radjenovic et al., 2009; Le-Minh et al., 2010:Snyder, 2007 \#1635;

Tambosi et al., 2010a; Sahar et al., 2011a; Sahar et al., 2011b; Sahar et al., 2011c; Dolar et al., 2012; García Galán et al., 2012; Schröder et al., 2012; Trinh et al., 2012b; Kim et al., 2014; Fenu et al., 2015; Phan et al., 2015; Qi et al., 2015; Tran et al., 2016; Trinh et al., 2016b; Park et al., 2017)

Enrofloxacin $<$ LOQ-56

(Baumgarten et al., 2007; Park et al., 2017)

Ciprofloxacin
(Baumgarten et al., 2007; Malpei et al., 2012; Kim et al., 2014; Tran et al., 2016; Park et al., 2017)

\section{Other pharmaceuticals/antimicrobials}

Diclofenac $\quad$ Clara et al., 2005a; Clara et al., 2005b; Kimura et al., 2005; Quintana et
al., 2005; Bernhard et al., 2006; González et al., 2006; Kim et al., 2007;
Kimura et al., 2007; Radjenovic et al., 2007; Snyder et al., 2007; Pérez
and Barceló 2008; Barceló et al., 2009; Radjenovic et al., 2009; Xue et
al., 2010; Sahar et al., 2011a; Sui et al., 2011; Lipp et al., 2012; Malpei et
al., 2012; Trinh et al., 2012b; Cartagena et al., 2013; Oosterhuis et al.,
2013; Phan et al., 2015; Qi et al., 2015; Arriaga et al., 2016; Trinh et al.,


Metformin

94-99

Carbamazepine

Lamotrigine

Triclosan
(Trinh et al., 2012b; Oosterhuis et al., 2013; Kim et al., 2014)

(Kreuzinger et al., 2004; Clara et al., 2005a; Clara et al., 2005b; Joss et

al., 2005; Bernhard et al., 2006; Kim et al., 2007; Radjenovic et al., 2007; Snyder et al., 2007; Barceló et al., 2009; Radjenovic et al., 2009; Xue et al., 2010; Sui et al., 2011; Dialynas and Diamadopoulos 2012; Dolar et al., 2012; Lipp et al., 2012; Malpei et al., 2012; Trinh et al., 2012b; Cartagena et al., 2013; Oosterhuis et al., 2013; Kim et al., 2014; Komesli et al., 2015; Phan et al., 2015; Qi et al., 2015; Arriaga et al., 2016; Arola et al., 2017; Park et al., 2017; Tran and Gin 2017)

(Bollmann et al., 2016)

(Kim et al., 2007; Snyder et al., 2007; Kantiani et al., 2008; Coleman et al., 2009; Trinh et al., 2012b; Cartagena et al., 2013; Tran et al., 2016;

Trinh et al., 2016b)

\section{Industrial Chemicals}

2,6-Ditert-butyl-4-

N.A.

methylphenol(BHT)

Tris(2-chloroethyl)

$<0-37$

phosphate (TCEP)

Tetrabromobisphenol A

$62-90$

Hexabromocyclododecane

N.A.

(HBCD)

Benzotriazole (BTA)

$15-74$

N-Nitrosodimethylamine

$70-94$

(dimethyl-nitrosamine)*

(NDMA)
(Potvin et al., 2012)

(Bernhard et al., 2006; Kim et al., 2007)

(Weiss and Reemtsma 2008; Sahar et al., 2011b; Qi et al., 2015; Arriaga et al., 2016)

(Gerrity et al., 2015; Mamo et al., 2016) 
Perfluorobutanoic acid

(PFBA)

Perfluoropentanoic acid

(PFPeA)

Perfluorohexanoic acid

(PFHxA)

\section{Estrogens}

\begin{tabular}{ll}
\hline Estrone (E1) & (Joss et al., 2004; Clara et al., 2005a; Joss et al., 2005; Zuehlke et al., \\
& 2006; Coleman et al., 2009; Le-Minh et al., 2010; Xue et al., 2010; Cases \\
& et al., 2011; Wu et al., 2011a; Trinh et al., 2012a; Trinh et al., 2012b; He \\
& et al., 2013; Phan et al., 2015; Trinh et al., 2016b) \\
& (Joss et al., 2004; Clara et al., 2005a; Zuehlke et al., 2006; Lee et al., \\
$17 \beta$-Estradiol (E2) & 2008; Le-Minh et al., 2010; Xue et al., 2010; Wu et al., 2011a; Dialynas \\
& and Diamadopoulos 2012; Trinh et al., 2012a; Trinh et al., 2012b; He et \\
& al., 2013; Trinh et al., 2016b) \\
& (Clara et al., 2004; Joss et al., 2004; Kreuzinger et al., 2004; Clara et al., \\
$17 \alpha$-Ethynylestradiol & 2005a; Zuehlke et al., 2006; Le-Minh et al., 2010; Xue et al., 2010; Wu et \\
(EE2) & al., 2011b; Dialynas and Diamadopoulos 2012; He et al., 2013; Trinh et \\
& al., 2016b)
\end{tabular}

\section{Personal care products}

2-Ethylhexyl N.A.
ethoxycinnamate (EHMC)

\begin{tabular}{ll}
\hline Neonicotinoids & \\
\hline Imidacloprid & N.A.
\end{tabular}

Thiacloprid

N.A.

Thiamethoxam

N.A.

Clothianidin

N.A. 
N.A.

\section{Pesticides}

Methiocarb

N.A.

Oxadiazon

N.A.

Triallate

N.A. 


\subsection{Constructed Wetlands}

Constructed wetlands (CWs) are treatment systems that use natural processes involving wetland vegetation, soils, and their associated microbial assemblages. As nature-based solutions, CWs have the potential to address societal and economical challenges related to safe water reuse. If well designed and maintained, CWs may provide effluents suitable for water reuse (Rousseau et al., 2008).

CWs are mainly used to efficiently remove organic matter, suspended solids, nutrients, and some metals from wastewater, and in recent years, CWs have been used also to remove organic pollutants, such as pesticides (Matamoros and Salvadó 2012), hydrocarbons (Guittonny-Philippe et al., 2015) and a few CEC (Gorito et al., 2017). Currently, CWs are recognized as a reliable wastewater treatment technology, representing a suitable solution for the treatment of many types of wastewaters, such as municipal or domestic wastewaters, storm water, agricultural wastewaters and industrial wastewaters (such as petrochemicals, pulp and paper, food wastes and mining industries) (Vymazal 2011a). Furthermore, due to their simple set-up and low maintenance, CWs can be used in rural areas, where the treated water can be reused in agriculture.

CWs are applied as a secondary treatment of municipal wastewater in relatively small communities, i.e. up to 1000 population equivalent $(\mathrm{PE})$, but can also be used for the treatment of wastewater from greater areas covering $2000 \mathrm{PE}$ (or more) (Vymazal 2011b). A limitation of the use of CWs for large, urbanized areas is associated with the higher area demand for these systems in comparison to the techniques based on activated sludge. Various examples exist on the removal of CEC in secondary treatments (Table 5 and Table SM4), and only a few applications of CWs for removing CEC during the polishing of wastewater effluent as a tertiary treatment are reported (Dordio et al., 2007; Imfeld et al., 2009; Bui and Choi 2010; Bhatia and Goyal 2014; Garcia-Rodríguez et al., 2014).

The removal efficiencies of the tested CEC are seasonally variable, with higher removal percentages in summer compared to winter (Garcia-Rodríguez et al., 2014; Li et al., 2014b). Furthermore, 
different designs exist, such as surface flow CWs (SF CWs), and sub-surface flow CWs with horizontal (HF) and vertical (VF) flows (Vymazal 2011b). Higher removal rates were found in systems with sub-surface flow (horizontal) CWs to surface flow CWs (Imfeld et al., 2009; Berglund et al., 2014; Bhatia and Goyal 2014; Li et al., 2014b; Díaz- Cruz and Barceló 2015). Other important parameters are water depth, HRT, vegetation type, temperature (seasonality), and substrate (CWs filling) type (Verlicchi and Zambello 2014; Zhang et al., 2014).

In the literature, various CWs applications for CEC removal are described, and details for the selected compounds are given in Table 5 and Table SM4, and described below. Current literature focuses on measuring influent and effluent concentrations of CEC to evaluate the overall removal performance, rather than detailed studies on the actual fate of target compounds or their removal pathways. CWs have shown the potential to remove CEC from urban/domestic wastewaters, including diclofenac, metformin, carbamazepine, triclosan, trimethoprim, clarithromycin, erythromycin, sulfamethoxazole, estrone, 17 $\beta$-estradiol, 17 $\alpha$-ethynylestradiol, and benzotriazole (see Table 5 and Table SM4 for details and percent removal efficiency). Diclofenac is the most studied CEC, described in almost $70 \%$ of the published studies on CEC removal in CWs (see Table 5). Other well-studied compounds are the pharmaceuticals carbamazepine and triclosan and the antibiotics trimethoprim and sulfamethoxazole.

In detail, many of the studied compounds showed removal up to $100 \%$. Nevertheless, the removal percentage is dependent on the CWs operational parameters, e.g. surface flow or subsurface flow (either horizontal or vertical) as can be seen in Table SM4. For instance, benzotriazole and trimethoprim were more effectively removed in vertical subsurface flow $\mathrm{CW}$ that in a surface flow CW. Especially the vertical sub-surface flow CWs are known to promote biodegradation. The water flow affects the redox conditions which in turn affects removal mechanisms, resulting e.g. in a better removal of metformin under oxic conditions in a sub-surface flow CW. Other factors, such as plants presence, plants species and temperature (seasonal) can also determine compounds removal. For 
instance, the removal of E1, E2 and EE2 increased in summer compared to winter. On the other hand, erythromycin and clarithromycin removals were favoured in the presence of plants, particularly in the presence of Iris tectorum. Triclosan removal was also favoured by a higher temperature and by the presence of the plant Phragmites australis. Details on these studies are given in Table SM4.

Despite the high removal rates observed for the above-mentioned compounds, at least three compounds showed limited removal in CWs, due to their more recalcitrant nature. Diclofenac, carbamazepine and sulfamethoxazole were poorly removed in most studies, with only 1 or 2 studies showing higher removal. For example, a reported removal of carbamazepine in sub-surface horizontal flow CWs higher than $88 \%$ is remarkable (Garcia-Rodríguez et al., 2014), as this pharmaceutical is known to be poorly biodegradable. The mechanism of carbamazepine removal has not been fully elucidated, but Garcia-Rodríguez et al., (2014) describe a relation between the removal efficiency and residence time in the $\mathrm{CW}$. The few parameters that are known to have a positive effect, e.g. vertical subsurface flow, higher temperature and plant presence, only slightly improved the removal of these three compounds. As a result, these 3 compounds are considered moderately removed by $\mathrm{CWs}$ indicating that $\mathrm{CWs}$ treatment should be combined with other wastewater treatments for an efficient removal of these compounds for wastewaters.

Other CEC, such as the antibiotics enrofloxacin (veterinary application) and ciprofloxacin, have not been mentioned in studies of urban/domestic wastewater CWs treatment. However, studies with e.g. livestock wastewater show the potential of CWs for secondary treatment (Hsieh et al., 2015; Almeida et al., 2017).So far, removal of the majority of industrial chemicals (see Table 5), neonicotinoids, and selected pesticides in a $\mathrm{CW}$ has not been described. Of the neonicotinoids, $100 \%$ removal of imidacloprid in a CW has been reported, although spiked water was used instead of real wastewater. These results indicate that more research on CWs applicability to remove these compounds from wastewater is needed. 
To conclude, CWs can be used for secondary treatment of wastewater containing selected CEC. There are several factors important when using a $\mathrm{CW}$, such as the available area, $\mathrm{CW}$ design and operational conditions and the impact of seasonal conditions. Just like CAS systems, current CWs are not able to entirely eliminate CEC from wastewater. The efficiency of the processes occurring in CWs depends primarily on the operation mode, design, type of substrate and the presence and type of plants. The effectiveness of the processes in the CWs can be increased by the use of hybrid systems, which combine CWs of different design connected in series (Vymazal 2011b; Garcia-Rodríguez et al., 2014; Verlicchi and Zambello 2014; Zhang et al., 2014; Díaz- Cruz and Barceló 2015). Combinations of CWs with other processes are also feasible, e.g. processes induced by sunlight (with/without photocatalysts) as the final stage of purification (Mahabali and Spanoghe 2013; Felis et al., 2016; He et al., 2016).

Table 5. Range of the removal efficiencies of selected CEC in different types of CWs ${ }^{\mathrm{a}}$

\begin{tabular}{lll}
\hline Category & $\begin{array}{l}\text { Removal } \\
\text { efficiency (\%) }\end{array}$ & References \\
\hline Antibiotics & $0-92$ & (Hijosa-Valsero et al., 2011a; Dan et al., 2013; Du et al., 2014; Chen et \\
\hline Trimethoprim & al., 2016; Ávila et al., 2017) \\
Erythromycin & al., 2016) \\
Clarithromycin & (Hijosa-Valsero et al., 2011a; Chen et al., 2016; Vymazal et al., 2017) \\
Azithromycin & N.A. & (Hijosa-Valsero et al., 2011a; Dan et al., 2013; Du et al., 2014; Chen et \\
Sulfamethoxazole & $0-75$ & al., 2016; Auvinen et al., 2017; Ávila et al., 2017) \\
& &
\end{tabular}




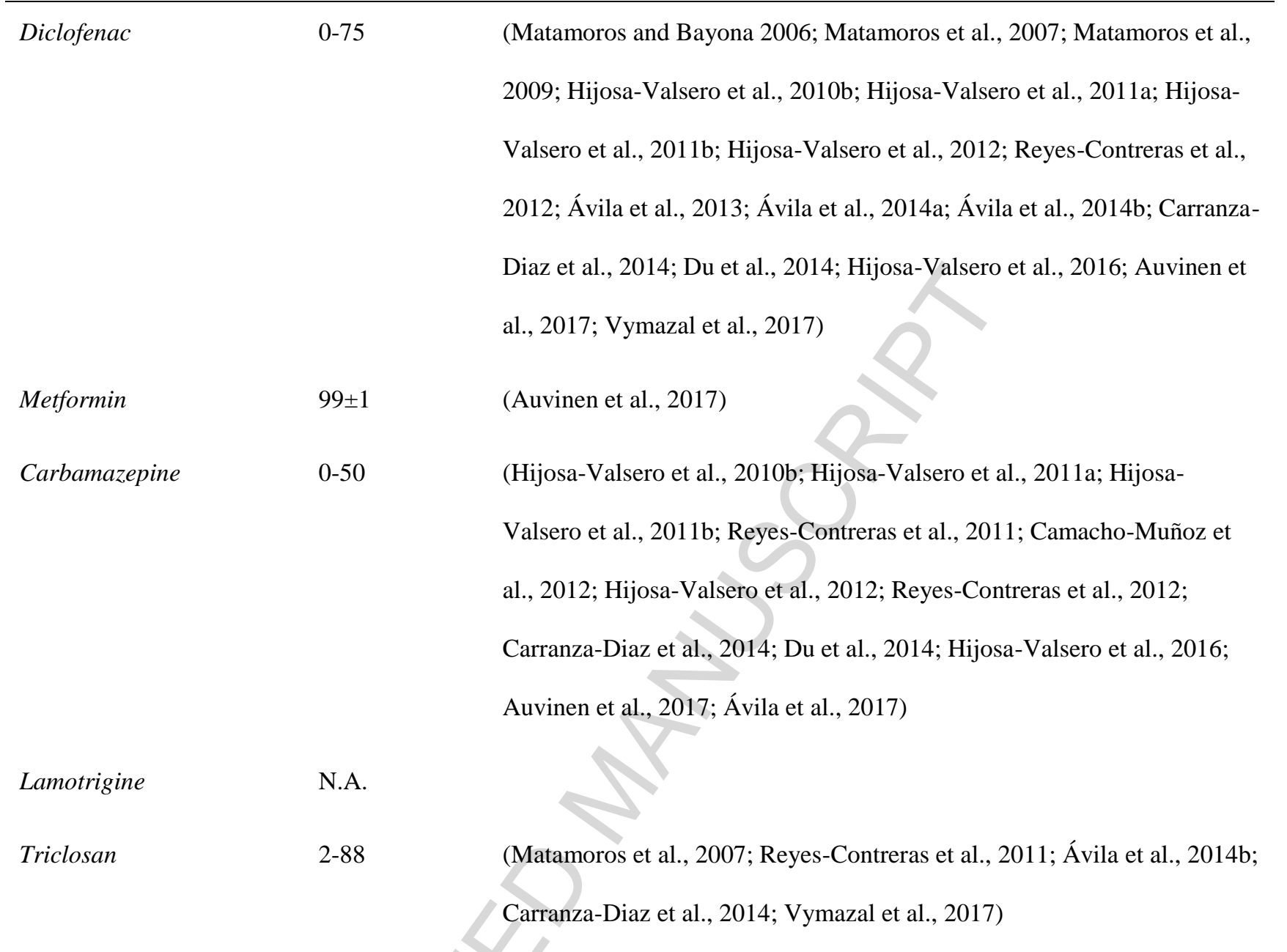

\section{Industrial Chemicals}

\begin{tabular}{ll}
\hline $\begin{array}{l}\text { 2,6-Ditert-butyl-4- } \\
\text { methylphenol(BHT) }\end{array}$ & N.A. \\
$\begin{array}{l}\text { Tris(2-chloroethyl) } \\
\text { phosphate (TCEP) }\end{array}$ & N.A. \\
$\begin{array}{l}\text { Tetrabromobisphenol A } \\
\text { Hexabromocyclododecane }\end{array}$ & N.A. \\
$\begin{array}{l}\text { (HBCD) } \\
\text { Benzotriazole (BTA) }\end{array}$ & 8 -100 \\
$\begin{array}{l}\text { N-Nitrosodimethylamine } \\
\text { (dimethyl-nitrosamine)* }\end{array}$ & N.A.
\end{tabular}


(NDMA)

Perfluorobutanoic acid

(PFBA)

Perfluoropentanoic acid

(PFPeA)

Perfluorohexanoic acid

(PFHxA)
N.A.

N.A

N.A.

\section{Estrogens}

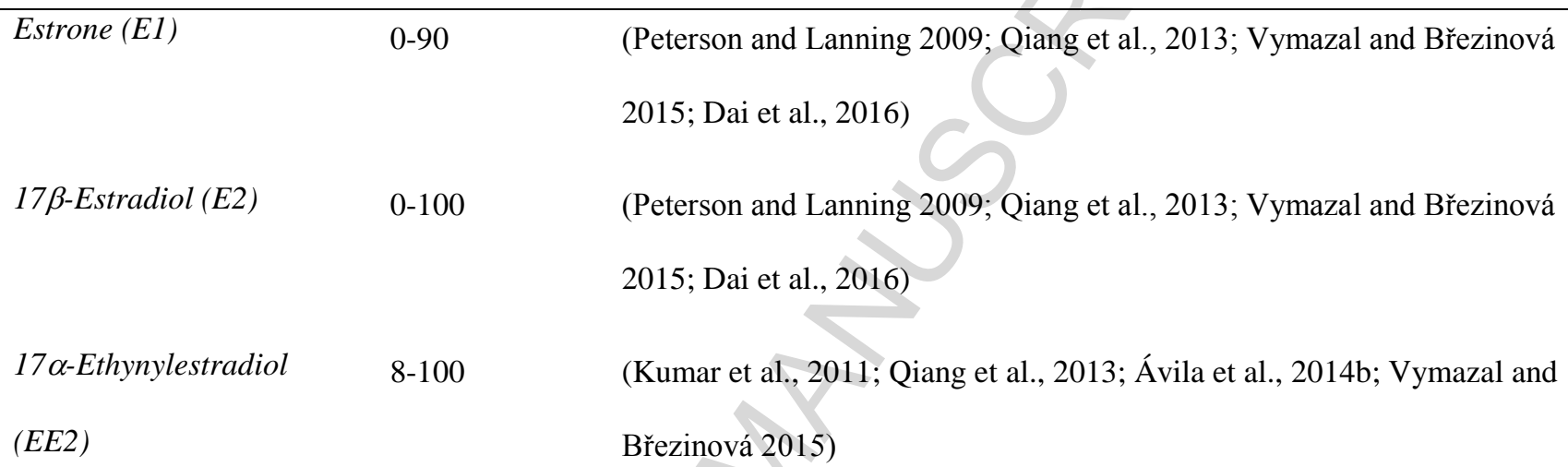

\section{Personal care products}

\begin{tabular}{l}
\hline 2-Ethylhexyl \\
N.A. \\
ethoxycinnamate (EHMC)
\end{tabular}

\begin{tabular}{ll}
\hline Neonicotinoids & N.A. \\
\hline Imidacloprid & N.A. \\
Thiacloprid & N.A. \\
Thiamethoxam & N.A. \\
Clothianidin & N.A. \\
\hline
\end{tabular}

\section{Pesticides}

\begin{tabular}{ll}
\hline Methiocarb & N.A. \\
Oxadiazon & N.A.
\end{tabular}




\subsection{Moving bed biofilm reactor}

Moving bed biofilm reactors (MBBRs) seem to be a promising alternative for the elimination of micropollutants. However, only few studies reported the application of the MBBR technology for CEC removal (Escola Casas et al., 2015a; Mazioti et al., 2015), and the studies based on real wastewater and full- to pilot-scale systems are missing. Therefore, lab-scale studies evaluating MBBR process as a secondary treatment for CEC removal from wastewater, which were based either on synthetic wastewater or hospital wastewater, are also considered. The contribution of biofilm communities (Torresi et al., 2017), its add-in value inside a hybrid MBBR system (Falas et al., 2013; Escola Casas et al., 2015b) or its contribution as a polishing treatment (Escola Casas et al., 2015b; Tang et al., 2017; Torresi et al., 2017) for CEC removal were also investigated. Details of these studies can be found in Table 6, Table SM5 and Table SM6.

The performance of an MBBR system for the removal of pharmaceuticals from pre-treated hospital raw wastewater was evaluated by Escola Casas et al., (2015a). The system consisted of three identical reactors in series, with biomass concentrations of $3.1,1.4$, and $0.5 \mathrm{~g} / \mathrm{L}$ respectively. The results showed that both high organic load (co-metabolism in the first reactor) and low organic load (more effective biofilm in the third reactor) acted for the overall removal of the pharmaceuticals. However, the comparison of the kinetic coefficient $\mathrm{k}_{\mathrm{biol}}$ between the three reactors showed that four pharmaceuticals had higher $\mathrm{k}_{\mathrm{biol}}$ in the third reactor (carbamazepine, clarithromycin, ciprofloxacin, and erythromycin) while diclofenac, sulfamethoxazole, and trimethoprim showed higher $\mathrm{k}_{\mathrm{biol}}$ in the second one. Escola Casas et al., (2015a) paved the way for the development of MBBR reactors with higher concentration of efficient biomass for the removal of recalcitrant pharmaceuticals. 
Mazioti et al., (2015) compared degradation of benzotriazole in CAS with a sludge return (HRT 26.4 $\pm 2.4 \mathrm{~h}), \mathrm{MBBR}$ at high organic load rate $(\mathrm{OLR})\left(0.25 \pm 0.16 \mathrm{~kg} \mathrm{~m}^{-3} \mathrm{~d}^{-1}, \mathrm{HRT} 10.8 \pm 1.2 \mathrm{~h}\right)$, and MBBR at low OLR $\left(0.6 \pm 0.4 \mathrm{~kg} \mathrm{~m}^{-3} \mathrm{~d}^{-1}\right.$, HRT $\left.26.4 \pm 2.4 \mathrm{~h}\right)$. Results showed similar removal efficiencies for the MBBR and CAS system at low OLR and worse results at high OLR. Specific removal $\left(\mu \mathrm{g} \mathrm{g}^{-1} \mathrm{~d}^{-1}\right)$ tripled between the first reactor at high OLR and the first reactor at low OLR $\left(11.9 \pm 1.3 \mu \mathrm{g} \mathrm{g}^{-1} \mathrm{~d}^{-1}\right)$ or the second bioreactor at high OLR $\left(11.0 \pm 5.3 \mu \mathrm{g} \mathrm{g}^{-1} \mathrm{~d}^{-1}\right)$. As co-metabolism (COD and $\mathrm{NH}_{4}$ ) showed nearly no differences for benzotriazole removal, this difference should be in relation with biomass specification even no bacterial communities' analysis was performed.

In general, the efficiency of biological process is linked with physicochemical characteristics of the compound $\left(\mathrm{k}_{\mathrm{biol}}, \mathrm{k}_{\mathrm{d}}\right)$ and process parameters (temperature, HRT, SRT, $\mathrm{pH}$, redox conditions). As MBBR is a biological process, the main removal mechanism is biodegradation which is quantified by the $\mathrm{k}_{\text {biol }}$ constant $\left(\mathrm{L} \mathrm{h}^{-1} \mathrm{~g}^{-1}\right)$. SRT, OLR, and nitrification rate are higher in MBBR and have a positive impact on CEC removal (Oulton et al., 2010).

These studies showed that both co-metabolism and balanced bacterial diversity could enhance CEC removal to some extent. The application of MBBR is not restricted to secondary biological treatment but may also have a successful future in polishing treatment. A comprehensive bibliographic review has been done on use of bacterial supports for the CEC removal and is summarized in Table 6, Table SM5 and Table SM6. 
Table 6. Range of the removal efficiencies of the selected CEC in MBBRs

\begin{tabular}{lll}
\hline $\begin{array}{l}\text { Category } \\
\text { efficiency (\%) }\end{array}$ & References \\
& & \\
\hline Antibiotics & $2-96$ & (Escola Casas et al., 2015a; Escola Casas et al., 2015b; Tang et al., 2017) \\
\hline Trimethoprim & $16-35$ & (Escola Casas et al., 2015a; Escola Casas et al., 2015b) \\
Erythromycin & $47-61$ & (Escola Casas et al., 2015a; Escola Casas et al., 2015b) \\
Clarithromycin & BDL-34 & (Escola Casas et al., 2015a; Escola Casas et al., 2015b) \\
Azithromycin & $(-28)-28$ & (Escola Casas et al., 2015a; Escola Casas et al., 2015b; Tang et al., 2017) \\
Sulfamethoxazole & $(-36)-21$ & (Escola Casas et al., 2015a; Escola Casas et al., 2015b; Tang et al., 2017) \\
Enrofloxacin & $2-96$ &
\end{tabular}

\section{Other pharmaceuticals/antimicrobials}

\begin{tabular}{ll}
\hline $\begin{array}{l}\text { Diclofenac } \\
\text { (Falas et al., 2013; Zupanc et al., 2013; Luo et al., 2014; Luo et al., 2015; }\end{array}$ & Tang et al., 2017) \\
N.A. & (Falas et al., 2013; Zupanc et al., 2013; Luo et al., 2014; Escola Casas et \\
$\begin{array}{l}\text { Metformin } \\
\text { Carbamazepine }\end{array}$ & al., 2015a; Escola Casas et al., 2015b; Luo et al., 2015; Tang et al., 2017) \\
& N.A. \\
Lamotrigine & (Luo et al., 2014; Luo et al., 2015) \\
Triclosan &
\end{tabular}

\section{Industrial Chemicals}

2,6-Ditert-butyl-4-

N.A.

methylphenol(BHT)

Tris(2-chloroethyl)

N.A.

phosphate (TCEP)

Tetrabromobisphenol A

N.A.

Hexabromocyclododecane N.A. 
$(H B C D)$

Benzotriazole (BTA)

43-76

(Mazioti et al., 2015)

$N$-Nitrosodimethylamine

N.A.

(dimethyl-nitrosamine)*

(NDMA)

Perfluorobutanoic acid

N.A.

(PFBA)

Perfluoropentanoic acid

N.A

(PFPeA)

Perfluorohexanoic acid

N.A

(PFHxA)

\section{Estrogens}

Estrone (E1)

65-95

(Luo et al., 2014; Luo et al., 2015; Amin et al., 2018)

$17 \beta$-Estradiol (E2)

95-100

(Luo et al., 2014; Luo et al., 2015; Amin et al., 2018)

$17 \alpha$-Ethynylestradiol

90-98

(Luo et al., 2014; Luo et al., 2015; Amin et al., 2018)

(EE2)

\section{Personal care products}

2-Ethylhexyl N.A.

ethoxycinnamate (EHMC)

\section{Neonicotinoids}

Imidacloprid

$$
\text { N.A. }
$$

Thiacloprid

N.A.

Thiamethoxam

N.A.

Clothianidin

N.A.

Acetamiprid

N.A.

\section{Pesticides}




\begin{tabular}{ll}
\hline Methiocarb & N.A. \\
Oxadiazon & N.A.
\end{tabular}

Triallate N.A.

\section{Effect of secondary treatments on microbial CEC fate}

Although antibiotic resistance and antibiotic residues may occur together in the environment, antibiotic resistance is not a direct consequence of chemical environmental contamination (Michael et al., 2013; Varela et al., 2014). Instead, ARB\&ARGs are emitted from human and animal sources, also irrespective of the occurrence of antibiotics, and have the capacity to survive or self-replicate in the environment. These arguments place ARB\&ARGs among the broad group of CEC (Pruden et al. 2006; Berendonk et al. 2015). Given the current state of the art and the knowledge gaps concerning the effect of secondary treatment on antibiotic resistance, this section discusses why urban wastewater treatment plants are reservoirs of ARB\&ARGs (Berendonk et al., 2015; Manaia et al., 2016) and why control strategies are so difficult to devise and implement. WWTPs collect most of the pharmaceutical compounds, including antibiotic residues which are increasingly used in the modern medicine and poorly metabolized in the human body (Segura et al., 2009; Segura et al., 2011; Michael et al., 2013). Unfortunately, antibiotic residues do not come alone. They are mingled with a wide diversity of human commensal and pathogenic bacteria, many of which harbour ARGs, acquired in a bacterial struggle for survival, while being able to persist and spread in the environment (Manaia et al., 2016). ARGs may be located on chromosomes or on plasmids, making the horizontal transfer of genes among neighbouring cells a possibility. Resistance genes encode different types of defence mechanisms that alone or in combination with other genetic determinants, may increase the capacity of bacteria to survive adverse conditions (Yomoda et. al., 2003; Kim et al., 2014).

Wastewater secondary treatment systems have the potential to offer ideal conditions for bacteria to spread their genes, in particular ARGs, and hence they can be associated with antibiotic resistance 
dissemination (Rizzo et al., 2013, Bouki et al., 2013). The wealth of nutrients and cell-to-cell interactions, aided by the presence of antibiotic residues and, eventually, other selectors, are believed to enhance the chances of survival or even proliferation of ARB (Berendonk et al., 2015; BengtssonPvaalme and Larsson, 2016).

The need of elucidating the potential impact of WWTPs on the dissemination of ARB\&ARGs has been urged by the accumulation of evidences that the use of reclaimed water used for irrigation may contribute to the transmission of $\mathrm{ARB}$ and other water-borne bacteria through different environmental compartments. Potential microbiological risks associated with water reuse in irrigation cannot be neglected (Pachepsky et al., 2012; Al-Jassim et al., 2015) and this review aimed at assessing what is known regarding ARB\&ARGs removal by full-scale WWTP systems operated with different secondary treatment technologies.

Recent studies on this topic that share common overall experimental approaches are reviewed in this paper (Table 7). Given the relevance of the disinfection effects on the fate of ARB\&ARGs and the difficulty in identifying the role of the secondary treatment units from the available literature, some data reported in the Table 7 includes also the disinfection step. A few aspects that can explain the variation in the data presented are worth mentioning (Table 7). First, diverse methodologies are used for the screening of genes in total DNA extracts or cultivation methods, a disparity that is enhanced by a wide array of variables that may influence the results. For culture-based methods, the results will be strongly influenced by the choice of the culture medium or the imposition of some selective pressures. For culture-independent methods, the DNA extraction process, the primers used for PCRbased gene search or the technique and conditions used for metagenome analyses as well as the database and analytical pipeline used, are enough to influence the results. Second, there is a lack of information on the external conditions during the full-scale conventional treatment, not only those referring to operational settings, but also climate conditions and numerous quality parameters. Third, the sampling scheme is different among studies and microbial targets analysed. In spite of such 
potential confounding variables, we can conclude that full-scale CAS plants have a limited capacity to reduce antibiotic resistance to negligible levels. In the next section, we will discuss the impact of the WWTP processes on: i) culturable total and ARB, ii) multi-drug resistance phenotypes, iii) ARGs and iv) metagenomics insights of antibiotic resistance.

\subsection{Fate of culturable antibiotic-resistant bacteria}

The reduction in the number of total and ARB has been examined in various studies, in the influent and secondary effluent of WWTP as a method to infer the efficiency of wastewater treatment to remove antibiotic resistance. This is achieved with the use of bacterial cultivation and enumeration methods, in selective media supplemented or not with antibiotics. This approach can be used to assess the effectiveness of the WWTP process as for instance is reported by Zanotto et al., (2016). These authors showed that a CAS process could reduce the ampicillin and chloramphenicol-resistant coliforms and Escherichia coli by 2 log units. However, the biological treatment did not reduce the percentage of ARB among total bacteria (maintenance of prevalence values). It has been shown in this study that the disinfection step with peracetic acid was important in the reduction of ampicillinresistant E. coli, to densities below $10 \mathrm{CFU} / 100 \mathrm{~mL}$. In contrast, in another study by Mao et al., (2015), it was observed that bacteria harbouring ARGs persisted throughout all treatment stages, surviving better after chlorination than total bacteria. Su et al., (2014) observed that even though total culturable bacteria and E. coli decreased after the WWTP process (2.3-3.3 log unit reduction), the quinolone- and ampicillin-resistant bacteria prevalence was not significantly reduced (from 55\% in the influent to $61 \%$ in the effluent). Sidrach-Cardona and Bécares (2013) have shown removal of 9099\% ARB from urban wastewater in CWs. This study showed that CWs design can affect the system performance, with planted sub-surface flow CWs being more efficient for this type of biological pollutants. Processes such as filtration, adsorption, aggregation, and metabolic activity of biofilm microorganisms and macrophytes are responsible for bacterial removal in CWs (García et al., 2008; Wu et al., 2016). It is not clear if plants have a direct effect on bacterial removal, as the presence of 
plants can indirectly increase removal through conductivity modification, gas transport and enhancement of biofilm development, adsorption, aggregation and filtration (García et al., 2008). The above suggest that the tertiary treatment is important in the removal of total bacteria, but it is not always effective in removing $\mathrm{ARB}$, thus leading to their persistence in the disinfected effluent, with possible contamination of the receiving environment.

\subsection{Multi-drug resistance phenotypes}

Multidrug-resistant (MDR) bacteria have been defined as those that have acquired non-susceptibility to at least one agent belonging to three or more antimicrobial categories (ECDC/EMEA, 2009). It was shown in several studies that MDR phenotypes occur in final effluent samples, evidencing that, as for many other bacteria, also MDR bacteria can survive treatment. Among the studies included in this review, there were MDR-positive isolates to the following antibiotics, among others: ciprofloxacin, trimethoprim and sulfamethoxazole/trimethoprim (Al-Jassim et al., 2015; Zhang et al., 2015b; Lopes et al., 2016; Osinska et al., 2017). The same pattern of MDR E. coli isolates was found by Osinska et al., (2017) and Lopes et al., (2016) in the wastewater effluent analysed, showing prevalence values above $30 \%$. The prevalence of MDR E. coli isolates reported by Blaak et al., (2015) was lower, but still represented $20 \%$ of the total number of isolates in effluent wastewater. Kotlarska et al., (2015) also reported MDR E. coli in wastewater effluent in two WWTPs (2.4 (0.1$6.1) \times 10^{5}$ and $2.1(0.8-3.1) \times 10^{5}$ CFUs per $\left.100 \mathrm{~mL}\right)$. Zhang et al., (2015b) selected 200 heterotrophic bacteria from three WWTPs (influent and effluent), seasonally. They reported MDR isolates ranging from 5 to $64 \%$. From these studies it is not possible to draw a general overview or define a trend. Apparently, more studies targeting MDR phenotype prevalence in wastewater effluents may be needed, preferentially targeting other bacteria besides E. coli. Another limitation is the use of ambiguous and not always correct definitions of MDR that are reported in the scientific literature, which may launch several misinterpretations of the meaning and impact of MDR in urban wastewater effluents. 


\subsection{Fate of antibiotic resistance genes}

The quantitative PCR (qPCR) of specific ARGs has brought a new breath to the assessment of wastewater treatment efficiency regarding the removal of antibiotic resistance genes. Rafraf et al., (2016) observed the presence of various ARGs including the integrase gene except bla $a_{C T X-M}$ in the influent and effluent samples of five WWTPs employing biological processes (CAS, CAS-UV, aerated lagoon). The quantification of the examined ARGs showed that there was no difference in their abundance before and after the treatment which is also in agreement with $\mathrm{Xu}$ et al., (2015), once more highlighting the tolerance of ARB and their associated genes to the applied WWTP treatments. This is supported by the study of Al-Jassim et al., (2015), where it was observed that tetO, tetQ, tet $W$, tet $H$, tet $Z$ were also present in the post-CAS chlorinated treated effluent. Wen et al., (2016) observed that the biological treatment had an important role in the removal of ARGs followed by UV disinfection, although high concentrations of ARGs were found in the treated effluents. Mao et al., (2015) observed a 90\% reduction in ARGs from influent to effluent in CAS. However, even after chlorination, the remaining ARGs were still in high levels, and tetA, tetB, tetE, tetG, tetH, tetS, tetT, tetX, sul1, sul2, qnrB and ermC were discharged through the dewatered sludge and plant effluent at higher rates than influent values. The latter finding is supported by the study of Alexander et al., (2015), where the abundance of various ARGs increased after conventional WWTP process, resulting in the surface water receiving a high abundance of various ARGs. Laht et al., (2014) demonstrated a decrease by several orders of magnitude in raw 16S rRNA and ARGs gene copy numbers (tetC, tetM, sull, sul2, bla $\left.a_{C T X-M-32}, b_{S H V-34}, b_{\text {bla }} a_{O X-58}\right)$ in the effluent compared to the influent, in three CAS WWTPs. In the same study, when the ARGs abundance was normalised per $16 \mathrm{~S}$ rRNA, it was shown that when relative abundances were compared, there was a statistically significant difference $(\mathrm{p}<0.01)$ between influent and effluent samples, in only four cases, among the three examined WWTPs. This is a finding which is in agreement with a study on CAS by BengtssonPalme et al., (2016). CWs have shown the removal potential of both antibiotics and antibiotic 
resistance genes in a few studies as reviewed by Sharma et al., (2016), which can ultimately affect the amount of antibiotic resistance bacteria in CWs effluents. In these studies, both domestic/urban and livestock wastewaters have been tested. For domestic/urban wastewaters, CWs can remove significant amounts of antibiotic resistance genes (45-99\%) belonging, for instance, to tetracycline, fluoroquinolone and sulfonamides antibiotic classes (Liu et al., 2013; Nolvak et al., 2013; Chen et al., 2015; Huang et al., 2015; Chen et al., 2016; Huang et al., 2017).

However, most of the papers present the removal results after a combined treatment process consisting of biological treatment and disinfection, and do not provide data on the actual biological process removal effectiveness. Therefore, it is not possible to clearly distinguish the effects of the biological treatment on the ARGs.

\subsection{Antibiotic resistance through the metagenomics lens}

Metagenomics approaches applied to resistome and bacterial community analyses have come into the spotlight in the last few years, due to the rapid technological development and reduction in the potential cost of such equipment. As a result, more studies are arising which perform in-depth analyses of the resistome and wastewater bacterial communities before and after WWTP processes. Christgen et al., (2015) explored five wastewater treatment options, such as: i) a completely mixed aerobic reactor (AER1), ii) an up-flow anaerobic sludge blanket reactor (UASB), iii) an anaerobic hybrid reactor (AHR), and iv-v) two anaerobic-aerobic sequence (AAS) bioreactors following UASB and AHR reactors, respectively. The analysis of the relative abundance of ARGs (abundance of ARG sequences reads the total reads number) showed that the AAS and aerobic treatment were able to remove a higher number of ARGs, among the total number of reads, such as aminoglycosides, tetracycline and $\beta$-lactam resistance genes compared to UASB and AHR, indicating the higher capacity of the combined aerobic system for ARGs removal, compared to the anaerobic processes. However, the relative abundance of sulfonamide and chloramphenicol 
resistance genes was unaffected by AAS. In another study (Yang et al., 2014), identified 271 subtypes of ARGs belonging to 18 classes. The highest abundance of ARGs among the total number of reads was observed in the influent of the WWTP, while 78 ARGs persisted throughout the treatment, among the total number of ARGs reads. Finally, significant statistical correlation between specific bacterial genera which include opportunistic pathogens, and ARGs distribution, was observed, suggesting their contribution as carriers of ARGs. 
Table 7. Most recent studies examining the fate of ARB\&ARGs in full-scale WWTPs operated with different processes and technologies

\begin{tabular}{|c|c|c|c|c|}
\hline $\begin{array}{l}\text { Country } \\
\text { \& Reference }\end{array}$ & $\begin{array}{c}\text { Process/ } \\
\text { Technology }\end{array}$ & $\operatorname{Aim}(s)$ & $\begin{array}{l}\text { Biological target/experimental } \\
\text { approach/chemical analyses }\end{array}$ & Study findings \\
\hline (Osinska et al., 2017) & $\begin{array}{l}\text { Conventional } \\
\text { Activated Sludge } \\
\text { (CAS) }\end{array}$ & $\begin{array}{l}\text { Compare antibiotic resistance and } \\
\text { virulence before and after CAS } \\
\text { treatment }\end{array}$ & $\begin{array}{l}\text { Isolates: E. coli resistant to amoxicillin, tetracycline } \\
\text { or ciprofloxacin } \\
\text { Approach: Isolation on } \mathrm{mFC} \text {, genotyping (ERIC- } \\
\text { PCR), antibiograms (3 antibiotics), gene detection } \\
\text { (PCR) }\end{array}$ & $\begin{array}{l}\text { Reduction of the counts of beta-lactam, tetracycline and fluoroquinolone-resistant E.coli } \\
\text { after treatment } \\
\text { Multi-drug resistance observed in } 38 \% \text { of the } 317 \text { isolates analysed } \\
\text { Most common antibiotic resistance genes: bla } a_{\mathrm{TEM}} \text { and bla } a_{\mathrm{OXA}} \text { and } t e t \mathrm{~A} \text {, tet } \mathrm{B} \text { and } t e t K \\
\text { Most common virulence genes: } b f p \mathrm{~A}, \mathrm{ST} \text { and } e a e\end{array}$ \\
\hline (Conte et al., 2017) & CAS & $\begin{array}{l}\text { Survey of beta-lactam and } \\
\text { quinolone resistant bacteria after } \\
\text { CAS treatment }\end{array}$ & $\begin{array}{l}\text { Isolates: E. coli, Klebsiella pneumoniae and K. } \\
\text { oxytoca resistant to quinolones } \\
\text { Approach: Isolation on MacConkey, genotyping } \\
\text { (ERIC-PCR), antibiograms ( } 9 \text { antibiotics) and MICs } \\
\text { (8 antibiotics), gene detection (PCR) }\end{array}$ & $\begin{array}{l}\text { Cephalosporin and quinolone resistance found in } 34.4 \% \text { of E. coli and } 27.3 \% \text { of } K \text {. } \\
\text { pneumoniae } \\
\text { Carbapenem resistance found in } 5.4 \% \text { of } K \text {. pneumoniae and } K \text {. oxytoca } \\
\text { ESBL-producing isolates found in raw and treated water samples } \\
\text { Ciprofloxacin residues were absent only in upstream river water }\end{array}$ \\
\hline (Ben et al., 2017) & $\begin{array}{l}\text { 1) Anaerobic/anoxi } \\
\text { c/oxic (Aº }\left(\mathrm{A}^{2} \mathrm{O}-\right. \\
\text { Membrane } \\
\text { Bioreactor } \\
\text { (MBR) } \\
\text { 2) Oxidation ditch- } \\
\text { coagulation/sedi }\end{array}$ & $\begin{array}{l}\text { Assess possible correlations } \\
\text { between antibiotic resistance and } \\
\text { sulfonamides (SA) or } \\
\text { tetracyclines (TC) in ten WWTPs } \\
\text { with different treatment types, all } \\
\text { of them including disinfection }\end{array}$ & $\begin{array}{l}\text { Isolates: Heterotrophic bacteria, resistant to } \\
\text { tetracycline and sulfamethoxazole } \\
\text { Total community DNA } \\
\text { Approach: Isolation on LA, gene quantification } \\
\text { (qPCR) } \\
\text { Antibiotics: Sulfonamides, tetracyclines }\end{array}$ & $\begin{array}{l}\text { ARGs detected after treatment in all } 10 \text { WWTP, with sulfonamide resistance being the most } \\
\text { abundant type of resistance } \\
\text { Total SA and TC concentrations were not significantly correlated with the corresponding } \\
\text { ARB\&ARGs } \\
\text { Positive correlation between ARGs and intI1 }\end{array}$ \\
\hline
\end{tabular}




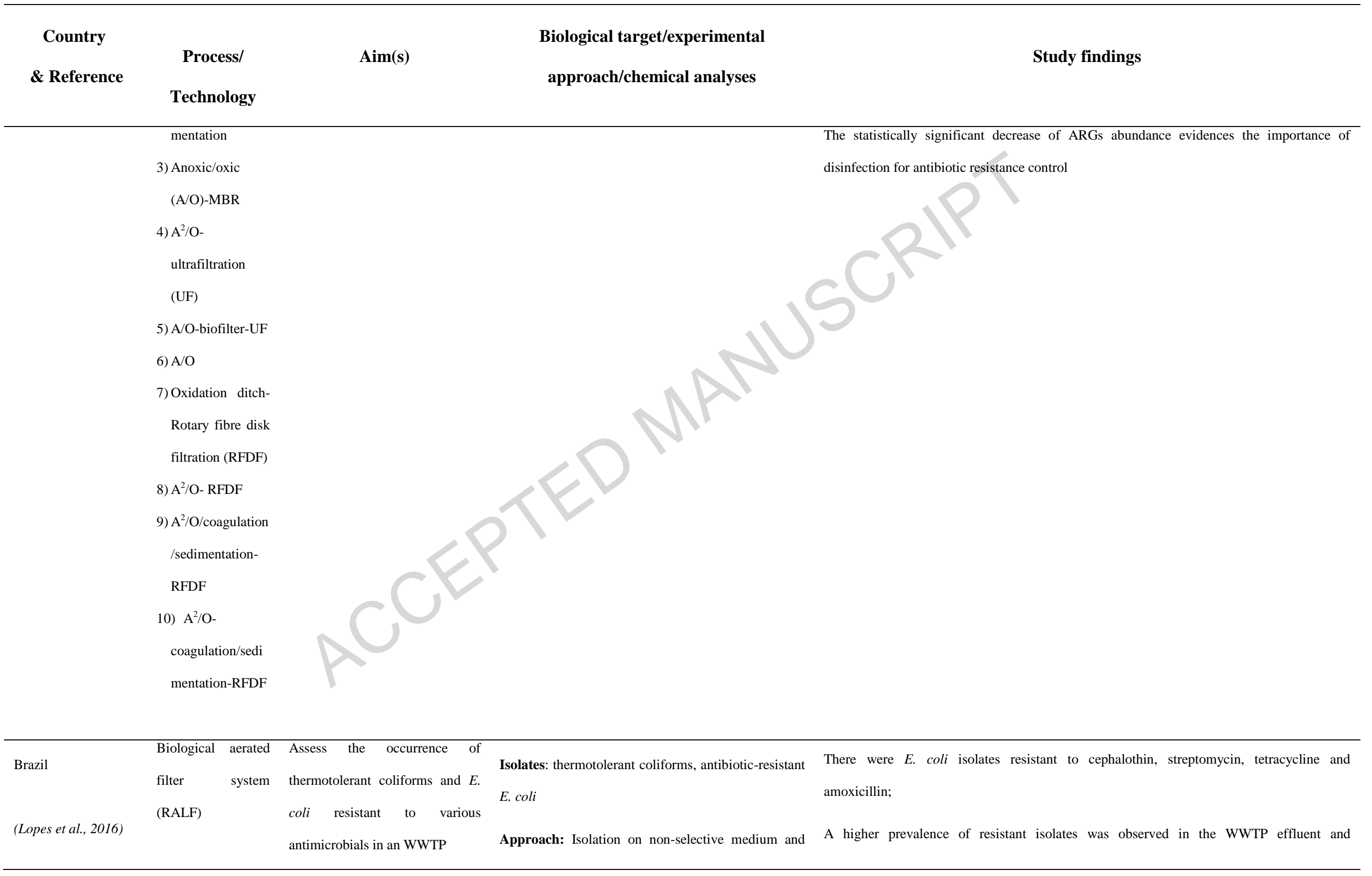




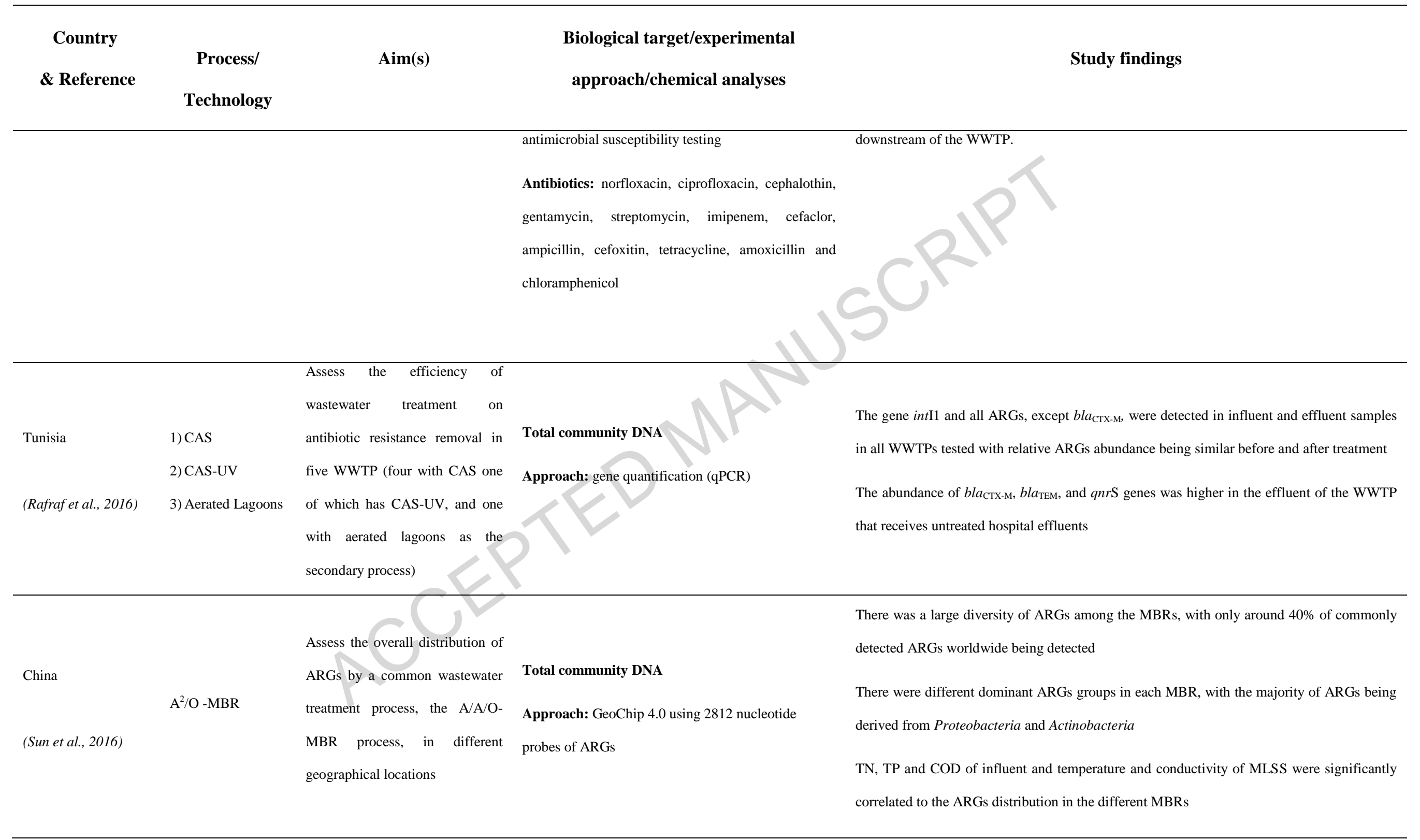




\begin{tabular}{|c|c|c|c|c|}
\hline $\begin{array}{c}\text { Country } \\
\text { \& Reference }\end{array}$ & $\begin{array}{c}\text { Process/ } \\
\text { Technology }\end{array}$ & $\operatorname{Aim}(\mathbf{s})$ & $\begin{array}{l}\text { Biological target/experimental } \\
\text { approach/chemical analyses }\end{array}$ & Study findings \\
\hline $\begin{array}{l}\text { Finland } \\
\text { (Karkman et al., } \\
\text { 2016) }\end{array}$ & CAS-Biofilter & $\begin{array}{l}\text { Assess seasonal variations of } \\
\text { transposase and ARGs abundance } \\
\text { in an WWTP utilizing CAS and } \\
\text { biofilters as tertiary treatment }\end{array}$ & $\begin{array}{l}\text { Total community DNA } \\
\text { Approach: gene detection (qPCR array) }\end{array}$ & $\begin{array}{l}\text { All transposases and } 66 \% \text { of all ARGs assayed were detected in the effluent and nine ARGs } \\
\text { were enriched in the effluent compared to the influent } \\
\text { WWTP with tertiary treatment system analyzed substantially decreased the gene abundance } \\
\text { and richness (>99\% reduction) }\end{array}$ \\
\hline $\begin{array}{l}\text { (Bengtsson-Palme et } \\
\text { al., 2016) }\end{array}$ & CAS & $\begin{array}{l}\text { Assess the occurrence of genes } \\
\text { against antibiotics, biocides and } \\
\text { metals and their co-selection } \\
\text { potential in WWTP utilizing the } \\
\text { CAS process }\end{array}$ & $\begin{array}{l}\text { Total community DNA } \\
\text { Approach: Metagenomics-Resistome } \\
\text { Antibiotics: Macrolides, fluoroquinolones, } \\
\text { tetracyclines, sulfonamides } \\
\text { Other: Metals, biocides }\end{array}$ & $\begin{array}{l}\text { No consistent enrichment of ARGs to any particular antibiotic class, for neither biocide nor } \\
\text { metal resistance genes } \\
\text { WWTP greatly reduced the number of resistance genes per volume of water, their relative } \\
\text { abundance per bacterial } 16 \mathrm{~S} \text { rRNA was only moderately decreased } \\
\text { A few resistance genes, including the carbapenemase gene bla } a_{\text {OXA-48, were enriched in the }} \\
\text { treatment process }\end{array}$ \\
\hline (Zanotto et al., 2016) & CAS-Peracetic acid & $\begin{array}{l}\text { Assess antibiotic resistance } \\
\text { dynamics over different treatment } \\
\text { stages (CAS and peracetic acid } \\
\text { disinfection) }\end{array}$ & $\begin{array}{l}\text { Isolates: Total coliforms, E. coli resistant to } \\
\text { ampicillin and chloramphenicol } \\
\text { Approach: Isolation on chromogenic agar, gene } \\
\text { detection (PCR) }\end{array}$ & $\begin{array}{l}\text { Biological process effective in the reduction of the ampicillin and chloramphenicol-resistant } \\
\text { total coliforms and E. coli by about 2-log units } \\
\text { No significant decrease of the percentage of ARB through the biological treatment } \\
\text { Disinfection significantly reduced the ampicillin-resistant E. coli }\end{array}$ \\
\hline (Wen et al., 2016) & $\begin{array}{l}\text { 1) } \mathrm{A}^{2} / \mathrm{O} \\
\text { 2) } \mathrm{A} / \mathrm{O} \\
\text { 3) Cyclic activated } \\
\text { sludge system } \\
\text { (CASS) }\end{array}$ & $\begin{array}{l}\text { Assess the distribution and } \\
\text { removal efficiency of ARGs in } \\
\text { four WWTPs with different } \\
\text { treatment processes }\end{array}$ & Approach: gene quantification (qPCR) & $\begin{array}{l}\text { Of all treatment steps, biological treatment played the most important role in ARGs removal, } \\
\text { followed by UV disinfection } \\
\text { ARGs were observed in all WWTP effluents after biological treatment process and their } \\
\text { abundance was still high in the final effluent }\end{array}$ \\
\hline
\end{tabular}




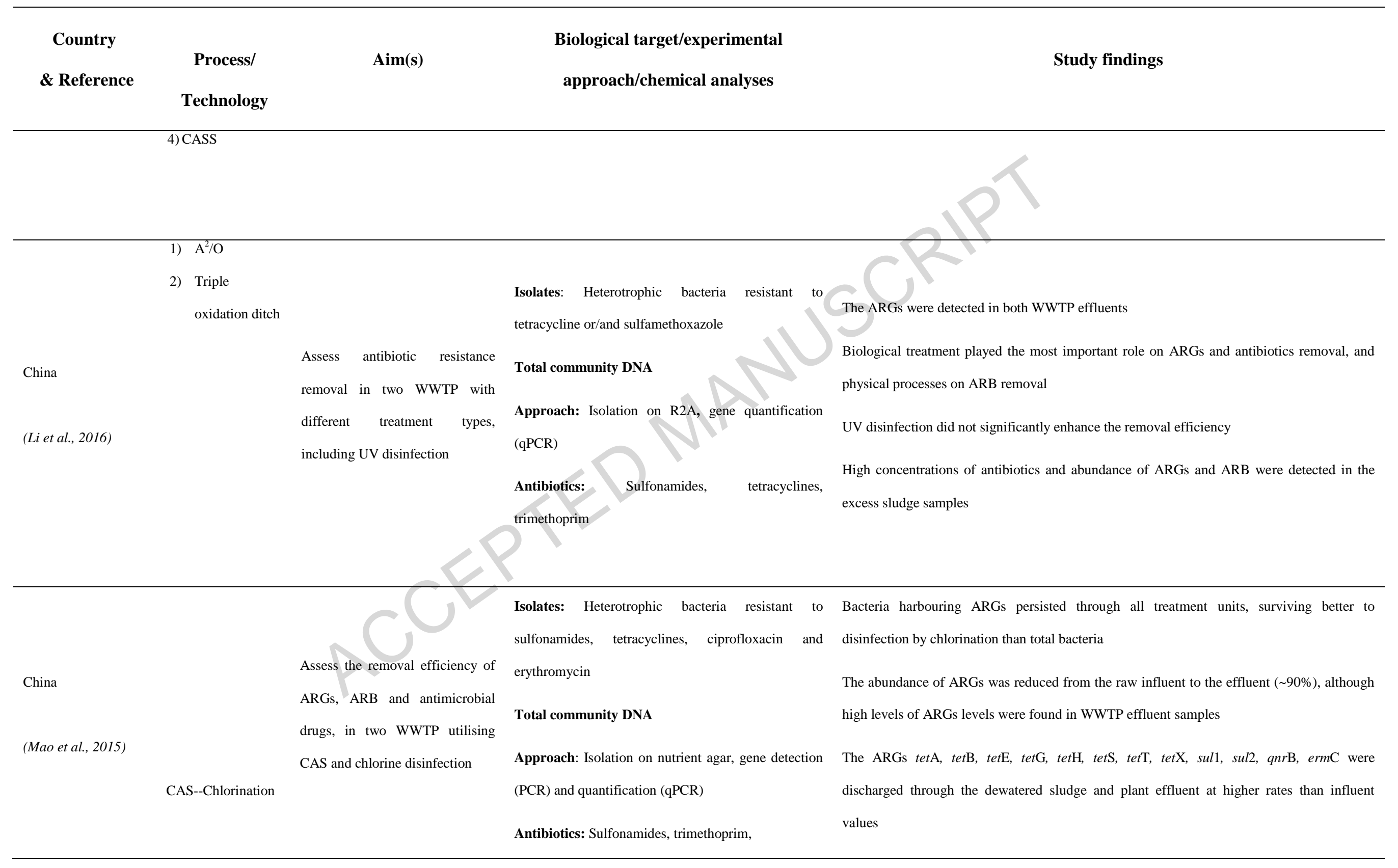




\begin{tabular}{|c|c|c|c|c|}
\hline $\begin{array}{l}\text { Country } \\
\text { \& Reference }\end{array}$ & $\begin{array}{l}\text { Process/ } \\
\text { Technology }\end{array}$ & $\operatorname{Aim}(s)$ & $\begin{array}{l}\text { Biological target/experimental } \\
\text { approach/chemical analyses }\end{array}$ & Study findings \\
\hline & & & $\begin{array}{l}\text { tetracyclines, } \beta \text {-lactams, fluoroquinolones, macrolides } \\
\text { Heavy metals: } \mathrm{As}, \mathrm{Cd}, \mathrm{Cr}, \mathrm{Cu}, \mathrm{Ni}, \mathrm{Pb}, \mathrm{Zn}\end{array}$ & 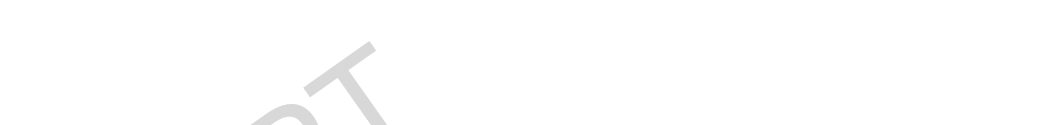 \\
\hline $\begin{array}{l}\text { USA } \\
\text { (Naquin et al., 2015) }\end{array}$ & CAS-UV & $\begin{array}{l}\text { Assess the presence of ARGs in a } \\
\text { small town WWTP utilizing CAS } \\
\text { followed by UV disinfection }\end{array}$ & $\begin{array}{l}\text { Isolates: Total bacteria } \\
\text { Total community DNA } \\
\text { Approach: Isolates on TSA, antibiograms, gene } \\
\text { detection (PCR), Genetic transformation assay } \\
\text { (mecA) }\end{array}$ & nt in both raw and treated wastewater during all the sampling periods \\
\hline $\begin{array}{l}\text { Saudi Arabia } \\
\text { (Al-Jassim et al., } \\
\text { 2015) }\end{array}$ & CAS-chlorination & $\begin{array}{l}\text { Assess the efficiency of removal } \\
\text { of microbial contaminants in a } \\
\text { WWTP utilizing CAS and } \\
\text { chlorine disinfection }\end{array}$ & $\begin{array}{l}\text { Isolates: Total heterotrophic bacteria, total and faecal } \\
\text { coliforms } \\
\text { Total community DNA } \\
\text { Approach: Isolation on nutrient agar, sulfate and } \\
\text { brilliant green bile lactose and EC, antibiograms (8 } \\
\text { antibiotics), bacterial community analysis, gene } \\
\text { quantification (qPCR) } \\
\text { Antibiotics: ampicillin, kanamycin, erythromycin, } \\
\text { tetracycline, ceftazidime, ciprofloxacin, } \\
\text { chloramphenicol, meropenem }\end{array}$ & $\begin{array}{l}\text { 16S rRNA gene-based community analysis showed that genera associated with opportunistic } \\
\text { pathogens (e.g. Acinetobacter, Aeromonas, Arcobacter, Legionella, Mycobacterium, } \\
\text { Neisseria, Pseudomonas and Streptococcus), were detected in the influent and some were } \\
\text { found in chlorinated effluent } \\
\text { The ARGs tetO, tetQ, tetW, tetH, tetZ were also present in the chlorinated effluent } \\
\text { The proportion of bacterial isolates resistant to } 6 \text { types of antibiotics increased from } 3.8 \% \text { in } \\
\text { the influent to } 6.9 \% \text { in the chlorinated effluent } \\
6.8 \% \text { of isolates from influent were resistant to meropenem and } 24 \% \text { of the isolates were } \\
\text { resistant in the chlorinated effluent } \\
25 \% \text { of the isolates in the influent and } 28 \% \text { of isolates in the effluent were resistant to at least } \\
5 \text { antibiotics }\end{array}$ \\
\hline
\end{tabular}




\begin{tabular}{|c|c|c|c|c|}
\hline $\begin{array}{l}\text { Country } \\
\text { \& Reference }\end{array}$ & $\begin{array}{c}\text { Process/ } \\
\text { Technology }\end{array}$ & $\operatorname{Aim}(\mathbf{s})$ & $\begin{array}{l}\text { Biological target/experimental } \\
\text { approach/chemical analyses }\end{array}$ & Study findings \\
\hline $\begin{array}{l}\text { United Kingdom } \\
\text { (Christgen et al., } \\
\text { 2015) }\end{array}$ & $\begin{array}{l}\text { 1. Upflow } \\
\text { anaerobic sludge } \\
\text { blanket reactor } \\
\text { (UASB)2. } \\
\text { Anaerobic hybrid } \\
\text { reactor (AHR)3. } \\
\text { Mixed aerobic } \\
\text { reactor (AER1) } \\
\text { 4. and 5. Anaerobic } \\
\text { aerobic sequence } \\
\text { bioreactor (AAS) }\end{array}$ & $\begin{array}{l}\text { Assess ARGs removal in five } \\
\text { different domestic wastewater } \\
\text { treatment options }\end{array}$ & Total community DNA & $\begin{array}{l}\text { The AAS and aerobic treatment achieved a higher removal of certain ARGs (aminoglycoside, } \\
\text { tetracycline, } \beta \text {-lactam resistance genes) compared to UASB and AHR, indicating the higher } \\
\text { capacity of the combined system to remove ARGs compared to each process alone } \\
\text { Sulfonamide and chloramphenicol resistance genes were unaffected by the AAS treatment } \\
\text { while multi-drug resistance increased from influent to effluent } \\
\text { Metagenomic data suggested that aerobic processes may be generally better than anaerobic } \\
\text { processes for reducing ARGs }\end{array}$ \\
\hline $\begin{array}{l}\text { Germany } \\
\text { (Alexander et al., } \\
\text { 2015) }\end{array}$ & $\begin{array}{l}\text { Nitrification- } \\
\text { denitrification- } \\
\text { phosphorus } \\
\text { elimination }\end{array}$ & $\begin{array}{l}\text { Detect and quantify genes and } \\
\text { gene carriers of clinical } \\
\text { significance; } \\
\text { Assess the dissemination of } \\
\text { ARGs and opportunistic bacteria } \\
\text { in natural populations; } \\
\text { Identify and monitor critical } \\
\text { water systems and potential } \\
\text { microbiological risks for human }\end{array}$ & $\begin{array}{l}\text { Total community DNA } \\
\text { Approach: Gene quantification (qPCR), } \\
\text { quantification of antibiotic residues (LC-MS) } \\
\text { Antibiotics: (Dehy-)erytromycin, Acetyl- } \\
\text { sulfamethoxazole, chloramphenicol, chlortetracycline, } \\
\text { clarithromycin, doxicycline, erythromycin, } \\
\text { metronidazole, oxytetracycline, roxithromycin, } \\
\text { sulfadiazine, sulfadimidine, sulfamerazine, } \\
\text { trimethoprim }\end{array}$ & $\begin{array}{l}\text { The removal capacities were up to } 99 \% \text { for some WWTPs tested, but not in all investigated } \\
\text { bacteria; } \\
\text { The abundance of most ARGs increased in the bacterial population after conventional } \\
\text { wastewater treatment. As a consequence, downstream surface water and also some } \\
\text { groundwater compartments displayed high abundances of all four ARGs }\end{array}$ \\
\hline
\end{tabular}




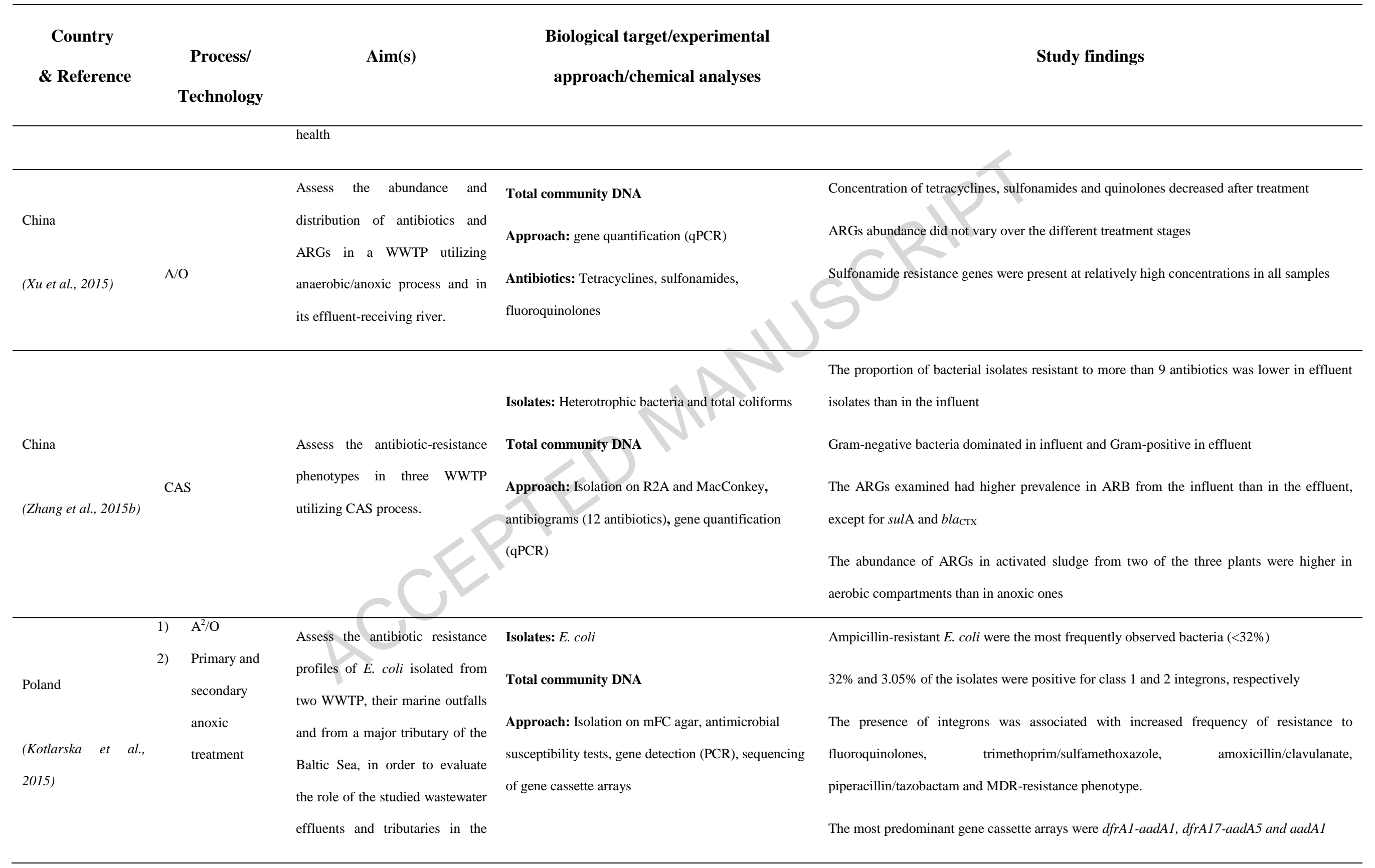




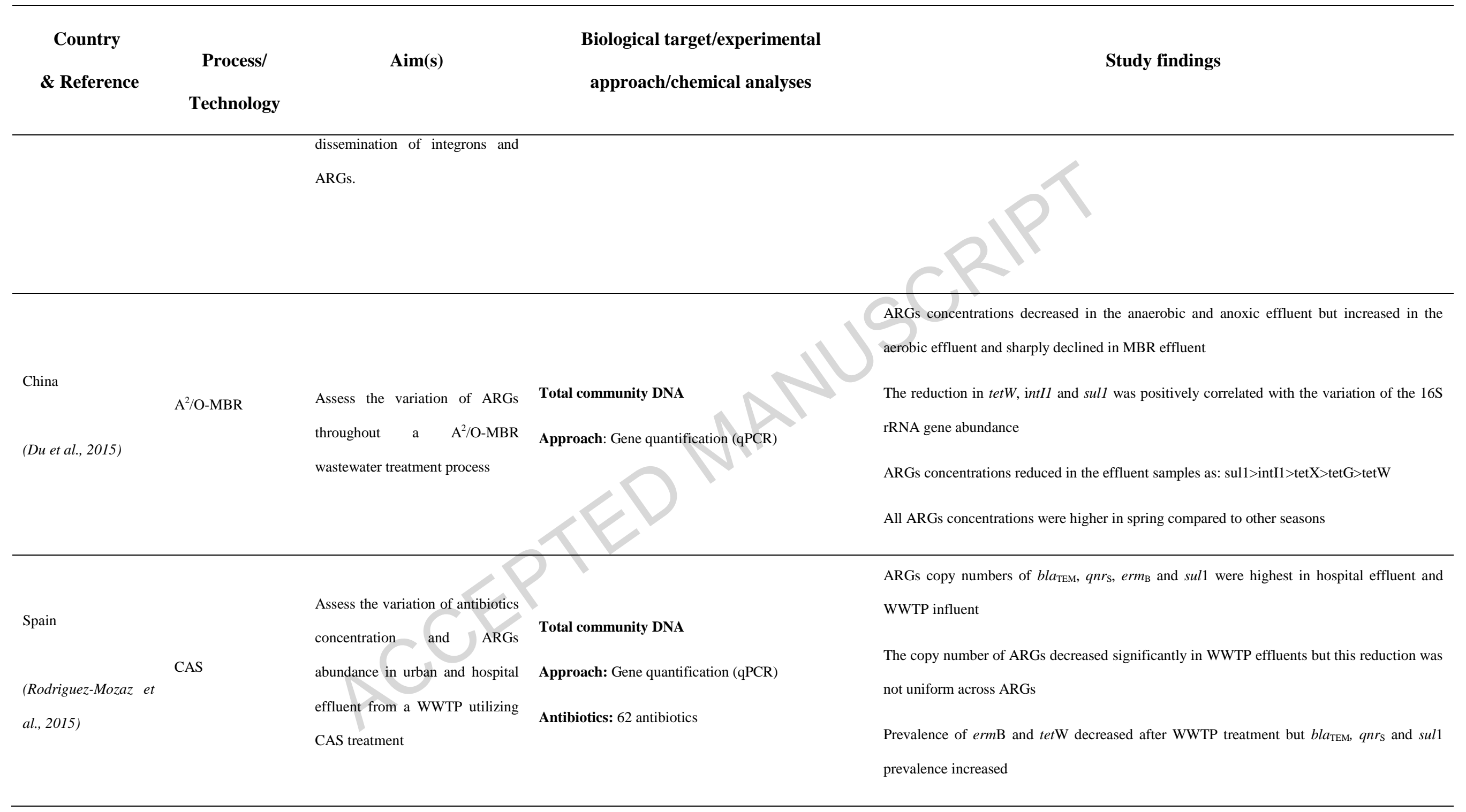




\begin{tabular}{|c|c|c|c|c|}
\hline $\begin{array}{l}\text { Country } \\
\text { \& Reference }\end{array}$ & $\begin{array}{c}\text { Process/ } \\
\text { Technology }\end{array}$ & $\operatorname{Aim}(\mathbf{s})$ & $\begin{array}{l}\text { Biological target/experimental } \\
\text { approach/chemical analyses }\end{array}$ & Study findings \\
\hline $\begin{array}{l}\text { Estonia and Finland } \\
\text { (Laht et al., 2014) }\end{array}$ & $\begin{array}{l}\text { CAS-Secondary } \\
\text { sedimentation }\end{array}$ & $\begin{array}{l}\text { Assess the role of three WWTP } \\
\text { utilizing CAS followed by } \\
\text { tertiary disinfection in the } \\
\text { distribution of ARGs }\end{array}$ & $\begin{array}{l}\text { Total community DNA } \\
\text { Approach: Gene quantification (qPCR) }\end{array}$ & $\begin{array}{l}\text { sull, sul2, and tetM were detected in all samples while statistically significant differences } \\
\text { between the influent and effluent were detected in only four cases } \\
\text { The purification process caused no significant change in the relative abundance of ARGs, } \\
\text { while the raw abundances fell by several orders of magnitude } \\
\text { Standard water quality variables }\left(\mathrm{BOD}_{7}, \mathrm{TP} \text { and TP, etc.) were weakly related or unrelated to }\right. \\
\text { the relative abundance of } \mathrm{ARGs}\end{array}$ \\
\hline $\begin{array}{l}\text { China } \\
\text { (Yang et al., 2014) }\end{array}$ & CAS & $\begin{array}{l}\text { Study the fate of ARGs in } \\
\text { WWTP utilizing CAS process }\end{array}$ & $\begin{array}{l}\text { Total community DNA } \\
\text { Approach: Metagenomics-resistome }\end{array}$ & $\begin{array}{l}271 \text { ARGs subtypes belonging to } 18 \text { ARGs types were identified by the broad scanning of } \\
\text { metagenomics analysis } \\
\text { Influent had the highest ARGs abundance, followed by effluent, anaerobic digestion sludge } \\
\text { and activated sludge } \\
78 \text { ARGs subtypes persisted through the biological wastewater and sludge treatment process } \\
\text { Significant correlation between specific bacterial genera, included potential pathogens, and } \\
\text { the distribution of ARGs were observed }\end{array}$ \\
\hline (Su et al., 2014) & $\begin{array}{l}\text { 1) CAS } \\
\text { chlorination } \\
\text { 2) CAS-oxidation } \\
\text { ditch-UV } \\
\text { disinfection }\end{array}$ & $\begin{array}{l}\text { Assess the effect of treatment on } \\
\text { antibiotic resistance profiles in } \\
\text { two WWTP utilizing: a) CAS } \\
\text { followed by chlorine disinfection } \\
\text { and b) oxidation ditch followed } \\
\text { by UV disinfection }\end{array}$ & $\begin{array}{l}\text { Isolates: } E \text {. coli resistant to quinolones and } \beta \text { - } \\
\text { lactams } \\
\text { Approach: Isolates on nutrient agar, modified mTEC } \\
\text { agar, antibiograms (12 antibiotics), gene detection } \\
\text { (PCR) } \\
\text { Antibiotics: ampicillin, piperacillin, cefazolin, }\end{array}$ & $\begin{array}{l}98.4 \% \text { of the isolates were resistant to the examined antibiotics and } 90.6 \% \text { were resistant to at } \\
\text { least } 3 \text { antibiotics } \\
\text { The number of the total cultivable bacteria and E. coli decreased after treatment } \\
\text { Disinfection significantly reduced total bacteria but not ARB prevalence }\end{array}$ \\
\hline
\end{tabular}




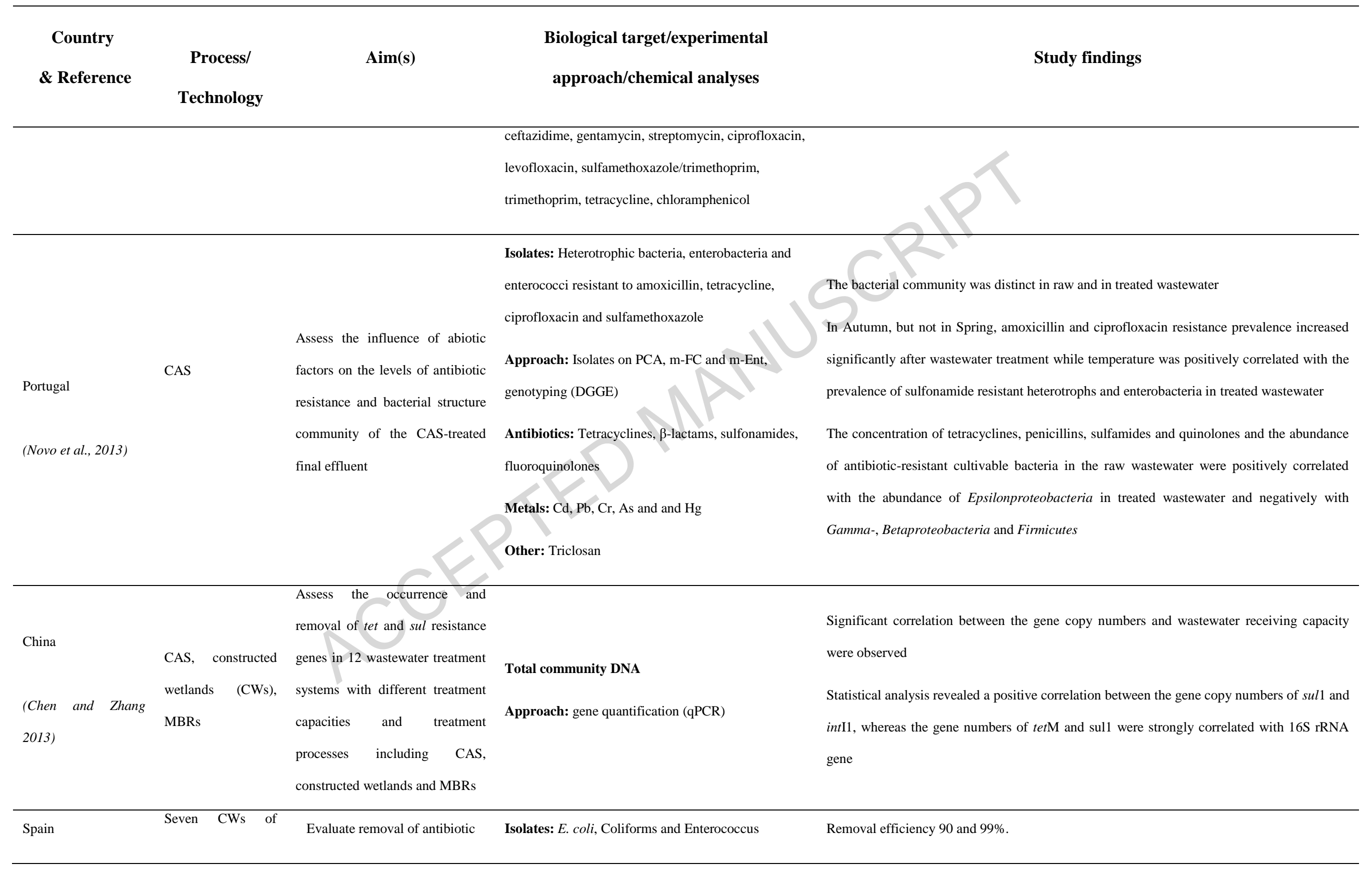




\begin{tabular}{|c|c|c|c|c|}
\hline $\begin{array}{l}\text { Country } \\
\text { \& Reference }\end{array}$ & $\begin{array}{c}\text { Process/ } \\
\text { Technology }\end{array}$ & $\operatorname{Aim}(s)$ & $\begin{array}{l}\text { Biological target/experimental } \\
\text { approach/chemical analyses }\end{array}$ & Study findings \\
\hline $\begin{array}{l}\text { (Sidrach-Cardona and } \\
\text { Bécares 2013) }\end{array}$ & different types & $\begin{array}{l}\text { resistant bacteria from urban } \\
\text { wastewater by CWs with } \\
\text { different design }\end{array}$ & $\begin{array}{l}\text { Approach: Isolates on coliform agar and SB agar } \\
\text { Antibiotics: amoxicillin, azithromycin, } \\
\text { amoxicillin+clavulanic acid, and doxycycline }\end{array}$ & $\begin{array}{l}\text { Better results for Sub-surface flow CW, planted with Phragmites spp. } \\
\text { Design parameters influencing their performance, those with sub-surface flow proving better } \\
\text { than hydroponic, and planted better than unplanted }\end{array}$ \\
\hline $\begin{array}{l}\text { Estónia } \\
\text { (Nolvak et al., 2013) }\end{array}$ & $\begin{array}{l}\text { Pilot system } \\
\text { consisted of a septic } \\
\text { tank, followed by } \\
\text { six parallel vertical } \\
\text { subsurface flow } \\
\text { mesocosms, a } \\
\text { collection well, and } \\
21 \text { parallel HSSF } \\
\text { MCs }\end{array}$ & $\begin{array}{l}\text { Evaluate removal of antibiotic } \\
\text { resistant genes from municipal } \\
\text { wastewater by CWs with } \\
\quad \text { different design }\end{array}$ & $\begin{array}{l}\text { Total community DNA } \\
\text { antibiotic resistance genes } \\
\text { Antibiotic: tetracyclines, macrolides, sulfonamides, } \\
\text { penicillins, and fluoroquinolones }\end{array}$ & $\begin{array}{l}\text { In general, the proportions of different ARGs decreased in mesocosm effluent bacterial } \\
\text { communities (compared to the influent) during the treatment process - no percentages } \\
\text { removal given } \\
\text { Antibiotic resistance genes in the wetland media biofilm and in effluent were affected by } \\
\text { system operation parameters, especially time and temperature }\end{array}$ \\
\hline (Chen et al., 2015) & $\begin{array}{l}\text { four surface and } \\
\text { subsurface flow- } \\
\text { CWs, and a } \\
\text { stabilization unit }\end{array}$ & $\begin{array}{l}\text { Evaluate removal of antibiotic } \\
\text { resistant genes from rural } \\
\text { domestic wastewater by CWs } \\
\quad \text { with different design }\end{array}$ & $\begin{array}{l}\text { Total community DNA } \\
\text { antibiotics leucomycin, ofloxacin, lincomycin, and } \\
\text { sulfamethazine }\end{array}$ & $\begin{array}{l}>99 \% \text { in total } \\
\text { CW3 with } 43.6 \% \text {, followed by CW2 (27.5\%), CW1 (11.9\%), and CW4 (11.9\%). The least } \\
\text { contributing treatment unit was CW5, with a contributing rate of } 2.6 \% \text { Sorption onto soil or } \\
\text { medium and biodegradation are two main mechanisms for ARGs elimination in the ICW } \\
\text { system. }\end{array}$ \\
\hline $\begin{array}{l}\text { China } \\
\text { (Chen et al., 2016) }\end{array}$ & $\begin{array}{l}\text { Six mesocosm- } \\
\text { scale CWs }\end{array}$ & $\begin{array}{l}\text { Evaluate removal of antibiotic } \\
\text { resistant genes Raw domestic } \\
\text { sewage by CWs with different } \\
\text { design }\end{array}$ & $\begin{array}{l}\text { Total community DNA } \\
12 \text { genes including three sulfonamide resistance genes } \\
\text { (sul1, sul2 and sul3), four tetracycline resistance } \\
\text { genes (tetG, tetM, tetO and tetX), two macrolide }\end{array}$ & $\begin{array}{l}\text { Removal efficiency between } 63.9 \text { and } 84.0 \% \\
\text { HSSF-CWs and VSSF-CWs showed higher removals of pollutants than the SF-CWs Planting } \\
\text { in the CWs was beneficial to pollutant removal. Mass removals attributed to biodegradation, } \\
\text { substrate adsorption, and plant uptake. }\end{array}$ \\
\hline
\end{tabular}




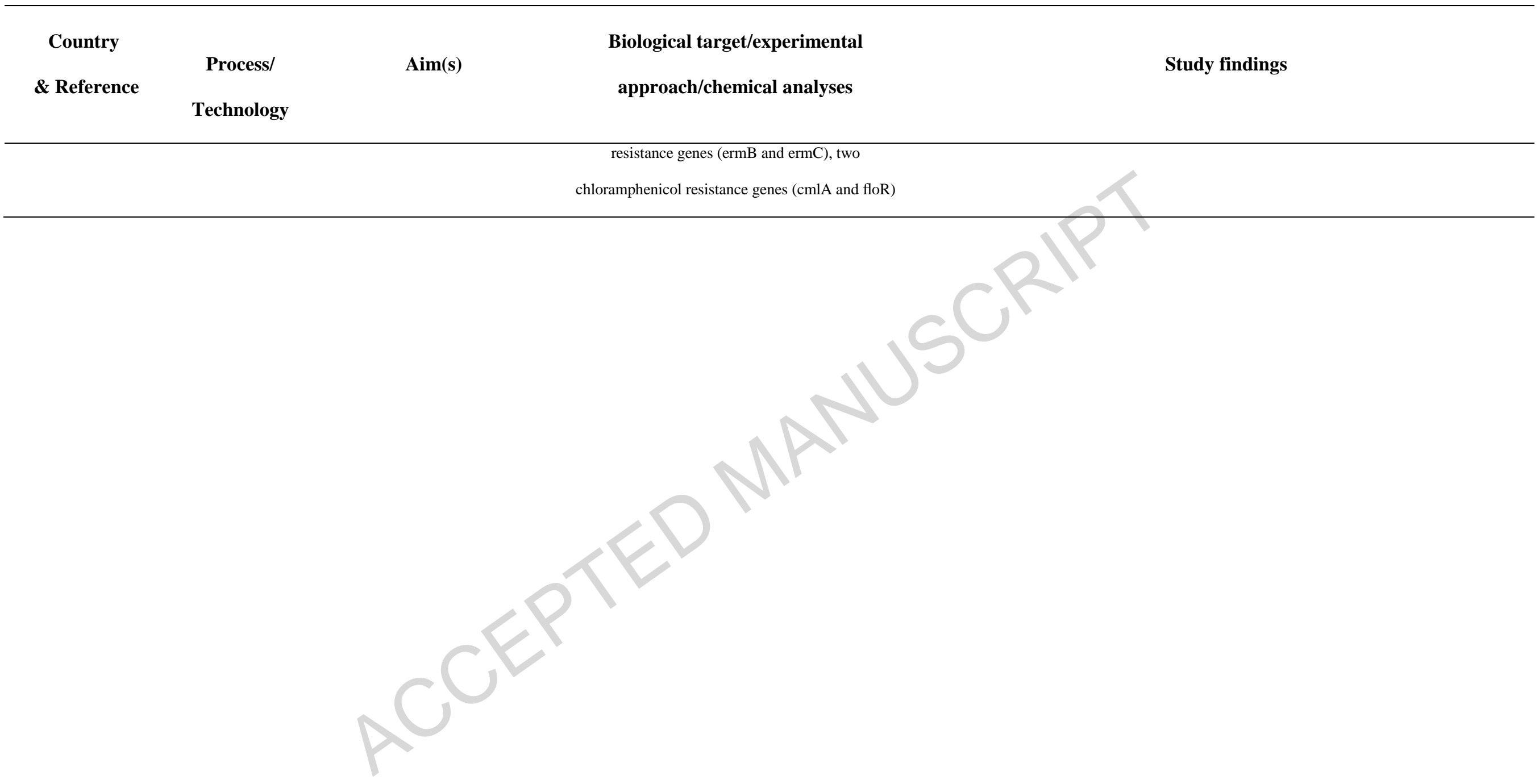




\section{WWTPs design, operation and upgrading for CEC removal: techno-economical evaluations}

\subsection{Impact of CEC removal implementation on WWTPs design and operation}

As pointed out in the previous sections, the effect of wastewater treatment on the fate of CEC occurring in wastewater depends on different factors including: (i) wastewater characteristics, (ii) initial concentration of target CEC, (iii) size of WWTPs, (iv) type of biological process/technology, (v) operating conditions of biological process/technology and (vi) presence of tertiary and/or advanced treatment. Wastewater characteristics also depend on the size of the WWTP because large WWTPs (e.g., > 50,000 - 60,000 PE) often collect hospital and industrial wastewater, while small WWTPs (SWWTPs, < 3,000 - 5,000 PE), particularly those in remote and/or rural area, are not or little affected by this kind of wastewaters. Moreover, treatment methods in medium/large WWTPs are basically different compared to small WWTPs. In medium/large WWTPs, CAS, MBRs or MBBRs are typical options for secondary (biological) treatment, while for small WWTPs (in particular for those in the low range of PE (e.g. $<1,000-2,000)$ some options may be not sustainable in terms of investment and management costs (e.g., MBRs) and cheaper solutions may be used (e.g., CWs, rotating biological contactors, Imhoff tanks, etc.).

Achieving CEC removal through optimization of existing WWTPs will vary between different treatment processes, but in general it will be based on adjustment of the operational process parameters typically proposed in the literature (Omil et al., 2010; Li et al., 2015; Tiwari et al., 2017) as well as of those, mentioned in early sections, which affect pollutants removal:

- Increased SRT to enhance biodegradation of typically moderately biodegradable compounds through microbial community diversification due to increased growth of slow growing microorganisms such as nitrifying bacteria at longer SRTs (Holbrook et al., 2002; Stephenson and Oppenheimer 2007; Tiwari et al., 2017). Although SRT of above 15 days are typically recommended ( $\mathrm{Li}$ et al., 2015), different CEC may require different SRTs for achieving optimal removal rate. Nevertheless, operation at very high SRT to promote extra biological transformation 
will lead to higher operating costs due to higher oxygen requirements of biomass (Krzeminski et al., 2017).

- Increased HRT to improve removal of compounds that are moderately biodegradable (high $\mathrm{k}_{\text {biol }}$ ) and have low sorption potential (low $\mathrm{K}_{\mathrm{d}}$ ) (Eggen and Vogelsang 2015). Enhanced CEC removal in CAS has been reported at HRT of above 16 hours (Guerra et al., 2014). However, HRT also increases capital costs while CEC removal improvement at higher HRT is still debated (Taheran et al., 2016).

- Increased MLSS to enhance biodegradation provided by high biological activity per unit volume leading to generation of slow-growing bacteria able to degrade certain biologically-recalcitrant pollutants (Bernhard et al., 2006; Sipma et al., 2010; Clouzot et al., 2011; Tran et al., 2013).

- Implementation of nutrient removal stages associated with varying redox conditions (nitrification and de-nitrification) leading to increased microbial diversity, broad enzymatic range and microorganisms' activity. Heterotrophic microbes are of importance for fast biodegradable compounds whereas lithotrophic ammonia oxidizers and nitrifyers are of importance for slowly biodegradable compounds (Tran et al., 2013). In particular, presence of anoxic zones and high ammonia loading rates seems to favour CEC removal in CAS (Li et al., 2015).

- Presence of fat during primary treatment that favours absorption of lipophilic compounds with high $\mathrm{K}_{\mathrm{ow}}$ such as musks (Li et al., 2015).

- Combination of different processes, such as CAS and CWs, or combination of CWs with different designs, as varying redox conditions should significantly improve pollutants removal.

The possibility of establishing favourable operating conditions for CEC removal is different for large/medium WWTPs and small WWTPs. For example, in CAS process, large WWTPs are operated with high organic loading rate (>0.5 kg BOD5/(kg MLVSS $\times \mathrm{d}))$, which typically results in designing aeration/nitrification tank with relatively low hydraulic retention time (HRT, $6-12 \mathrm{~h}$ ) and sludge 
retention time (SRT, $3-6$ d). Differently, CAS process in SWWTPs is typically designed to operate under extended aeration conditions $(<0.05 \mathrm{~kg} \mathrm{BOD} 5 /(\mathrm{kg}$ MLVSS $\times \mathrm{d})$, which results in larger aeration/nitrification tank (HRT $=36-48 \mathrm{~h}, \mathrm{SRT}=30-40 \mathrm{~d})($ Metcalf and Eddy 2003).

Other factors influencing CEC removal often mentioned in the literature, such as temperature, content of organic matter, ionic strength and conductivity, were considered less realistic for implementation at the full-scale, and thus not discussed further.

\subsection{Feasibility of WWTPs upgrading to remove CEC}

Possible solutions to successfully minimize the release of CEC into the environment from WWTPs effluents consist of implementation of an effective tertiary treatment, upgrading through re-designing of the existing treatment processes or optimizing operating conditions of the existing biological process according to the flow chart reported in Figure 1.

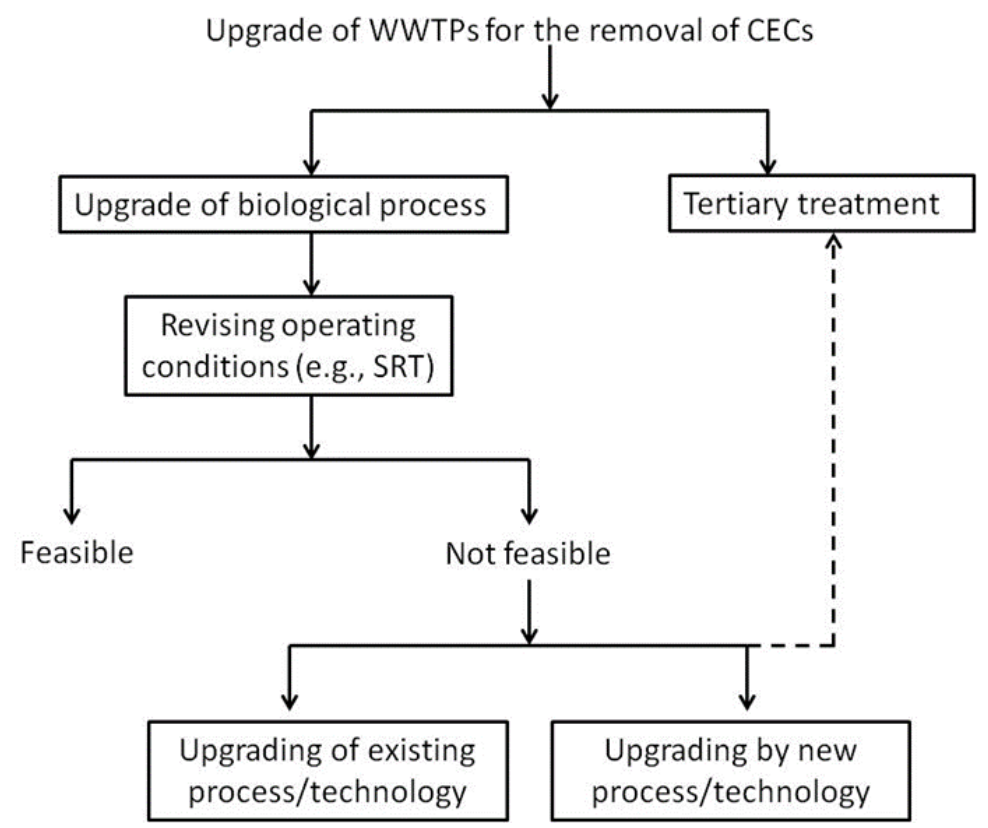

Figure 1: Flow chart for decision making on upgrading conventional WWTPs for CEC removal 
The likelihood of implementation of dedicated treatment for CEC removal depends not only on the performance aspects of particular process such as removal efficacy and removal mechanisms, range of treated pollutants and reliability of removal efficiency, but also on significant number of other factors. Among these impact factors, ease of construction and set-up, simplicity of operation and maintenance requirements, flexibility in adapting to the fluctuations in influent flowrate and characteristics, capital and operating costs, cost-effectiveness, environmental friendliness in respect to waste production and disposal needs, overall environmental footprint, associated prospects and constraints, development stage, level of social acceptance, and finally who is supposed to cover the costs of dedicated CEC treatment are mentioned (Eggen and Vogelsang 2015; Bui et al., 2016; Tiedeken et al., 2017).

However, proper economic comparison between different treatment alternatives discussed in this review is very difficult due to scarce information in the literature (Bolzonella et al., 2010; Fatone 2010; Krzeminski et al., 2017) and because each treatment design is unique due to its specific site conditions and operating settings/conditions. The capital and operating costs depend on number of parameters such as scale of treatment, feed water characteristics, targeted pollutants, desired water quality and electricity, chemicals and personnel costs, which vary from country to country (Bui et al., 2016; Taheran et al., 2016).

Furthermore, holistic assessment of different alternatives taking into account environmental impacts is needed to quantify benefits of CEC removal. Approaches, such as Life Cycle Assessment (Corominas et al., 2013), nonmarket valuation (Kotchen et al., 2009; Logar et al., 2014) and distance function approach based on shadow prices, to quantify environmental benefits from reduced discharges of CEC (Molinos-Senante et al., 2013) have been proposed (Schröder et al., 2016; Tiedeken et al., 2017). For example, research findings of the LCA studies review (Corominas et al., 2013) indicate that in general environmental benefits do not outweigh the costs of advanced treatment implementation. However, LCA studies evaluating secondary treatment alternatives for the removal of CEC to the best authors' knowledge have not been published. 
Alternatively, in cases when the implementation costs would outweigh the environmental benefits, or if cost would be considered too great, existing WWTPs could be optimized for CEC removal (Jones et al., 2007) by adjusting operating parameters reported in the previous section.

\subsection{Techno-economical comparison of the selected technologies}

To define the technology to be implemented for achieving a more effective removal of the selected CEC and producing effluents suitable for re-use, a comparison of the proposed technological solutions, summarizing the data reported in the manuscript, is reported in Table 8 . In order to achieve an integrated, coherent comparative efficiency assessment of the examined technologies, besides the achievable removal efficiencies, other evaluation parameters such as complexity in lay out and management, scale of application and need of a post-treatment are included. It is worth noting that updated specific quantitative cost data related with CEC removal in discussed secondary treatment processes are not available in scientific literature, thus a qualitative evaluation based on the literature review has been performed, where some important economic factors (i.e. energy and chemical consumptions) are being discussed.

In addition, with the objective to give a first simplified comparative evaluation of the technologies, a score was assigned in a scale from 1 to 4 , where 1 is the worst and 4 is the best evaluation of each technology, according to each examined parameter. The score was determined based on the available technical data elaborated for the purposes of this review.

The ARB\&ARGs removal figures are not reported in Table 8 because data available is scarce and not following a systematic protocol of analyses, leading to results biased by large variability in the nature of approaches reported in the existing in scientific literature so far. Majority of studies examines prevalence of resistance in selected isolated colonies and does not focus on the removal of ARB\&ARGs as such. In addition, many studies report removal efficiencies at the end of the WWTP which may involve a tertiary or disinfection step and do not provide data on the actual biological process removal efficiency. 
Table 8. Techno-economical comparative evaluation of the proposed technologies to produce effluents suitable for reuse. Data for the different groups of CEC are with reference to the ones included in this review. A score assigned in a scale from 1 to 4 (where 1 is the worst and 4 is the best evaluation of each technology according to the examined parameter) is reported in parentheses.

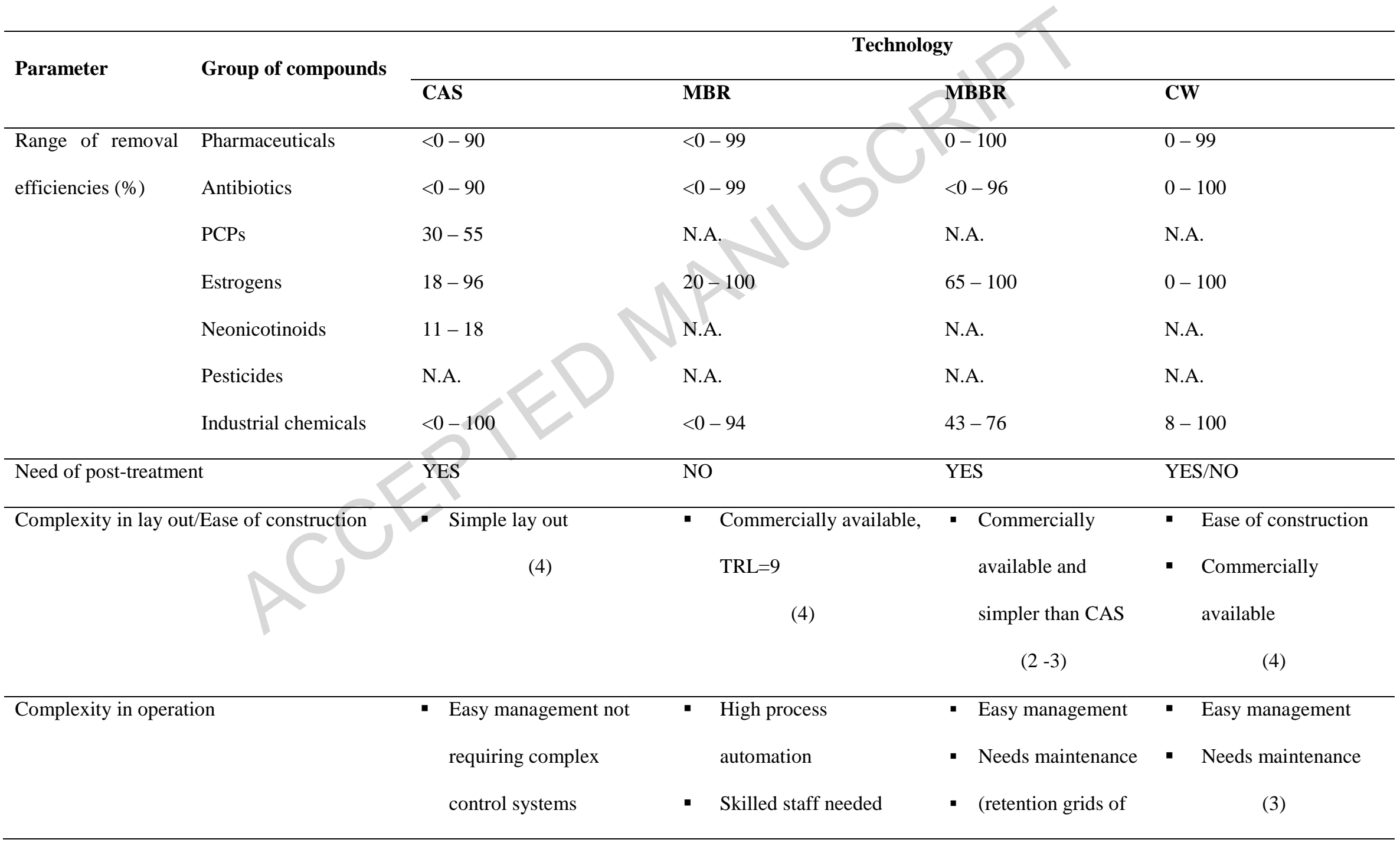




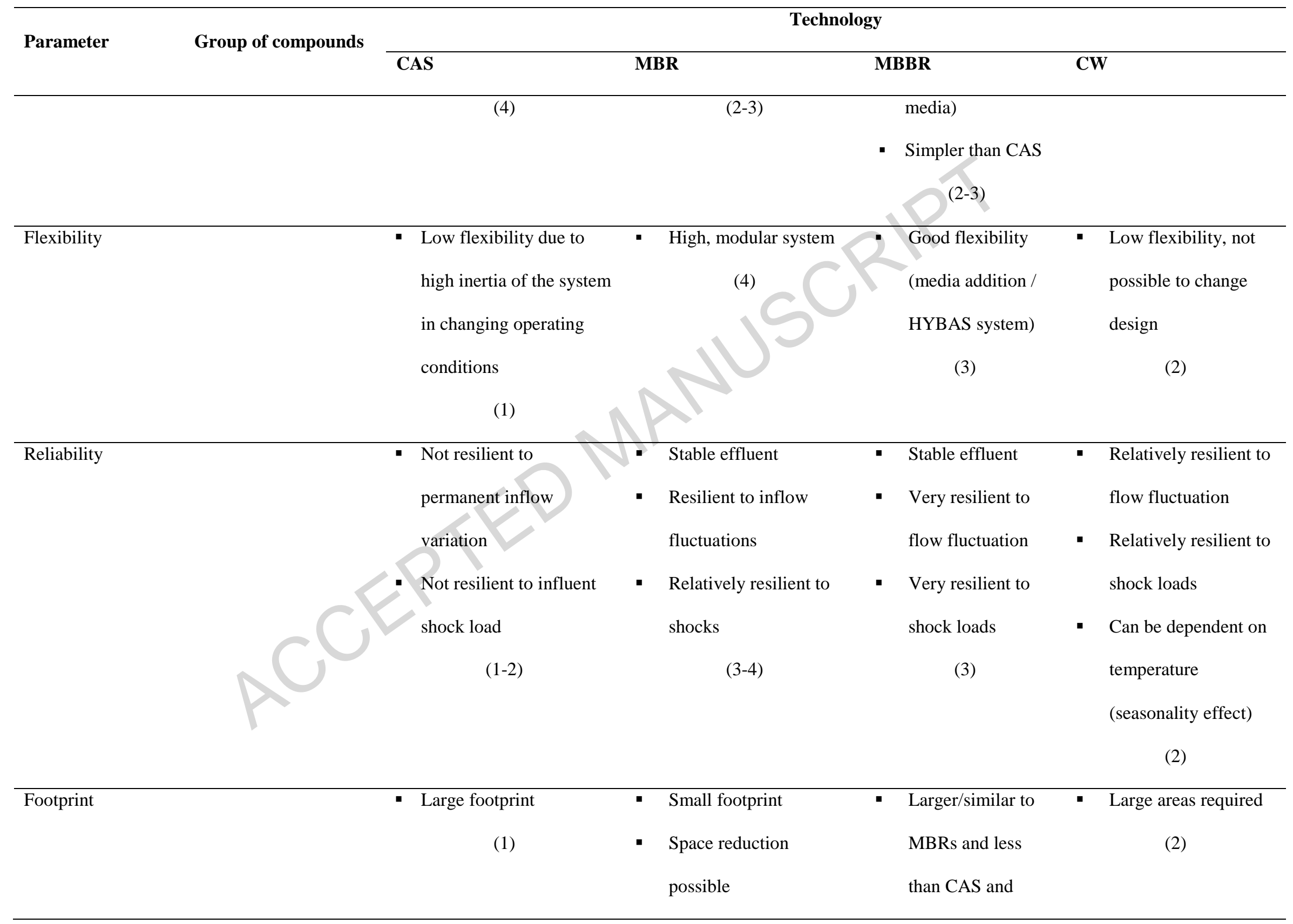




\begin{tabular}{|c|c|c|c|c|}
\hline \multirow{2}{*}{ Parameter } & \multirow{2}{*}{ Group of compounds } & \multicolumn{3}{|c|}{ Technology } \\
\hline & & MBR & MBBR & CW \\
\hline
\end{tabular}

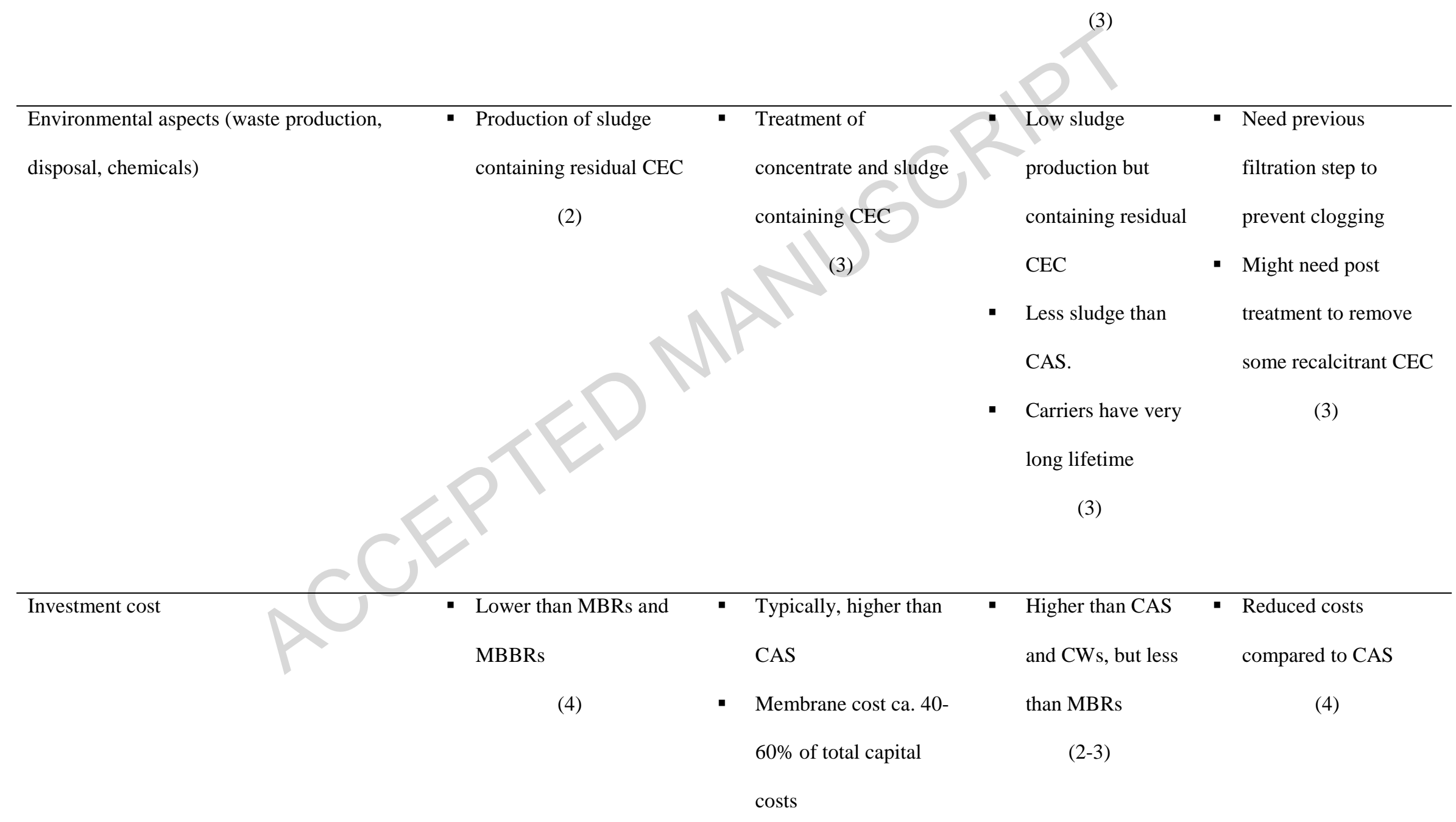

(2) 


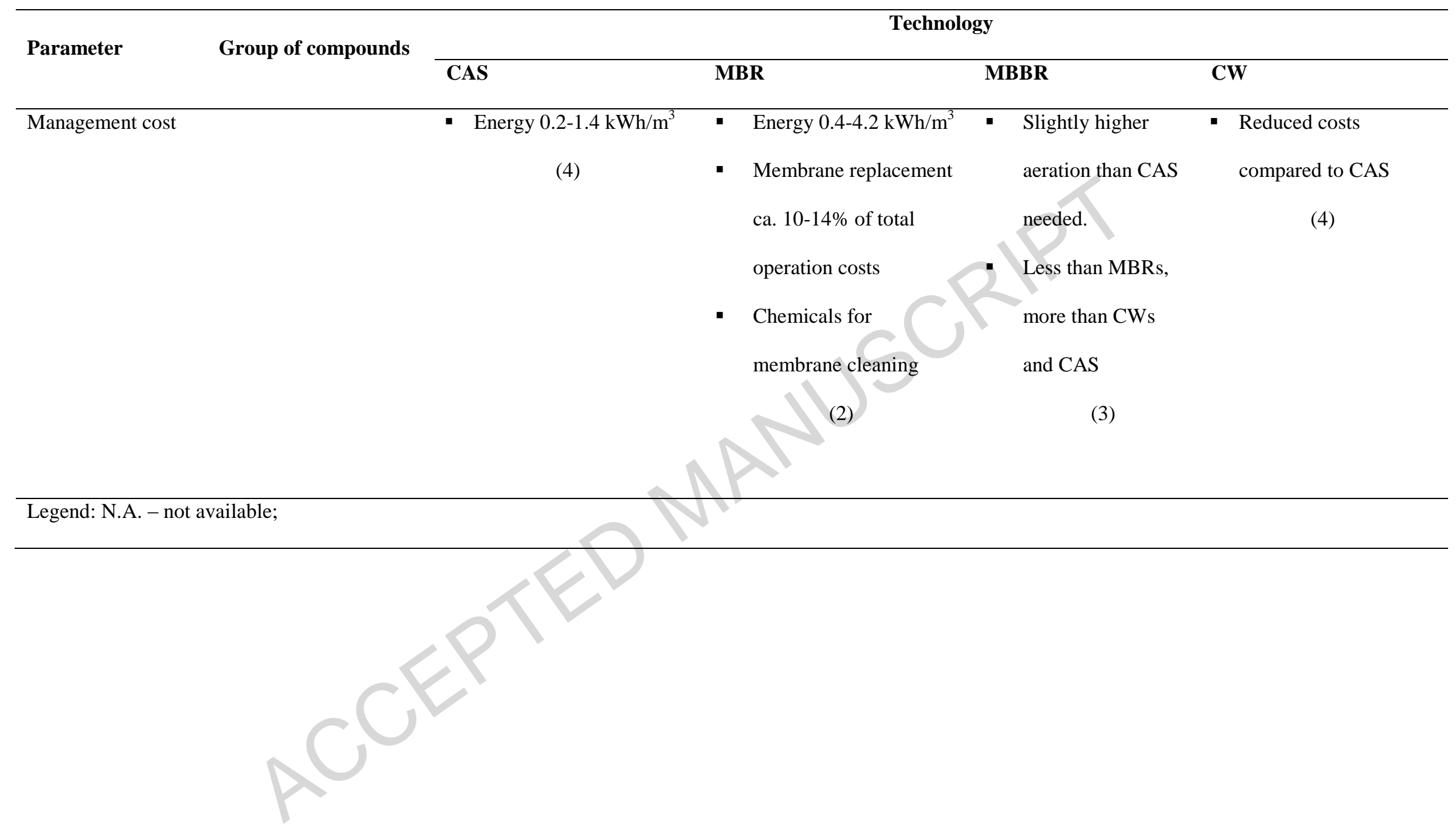




\section{Future perspectives and research needs}

Despite significant research and monitoring efforts devoted to presence and fate of CEC, data on occurrence and/or removal of some of the emerging compounds are not available. Nevertheless, this review shows the potential of four secondary biological treatment technologies for the removal of selected CEC and the need to reach effluent quality suitable for reuse of treated water for e.g. irrigation purposes. This in turn, allows defining the research needs for the analysed technologies in respect to the removal of CEC.

CAS process is the most investigated process for the removal of CEC. However, the conventional layout (i.e. aerobic process) is ineffective, while operation at high SRT or with sequential anoxicaerobic phases can ameliorate their performance for some pharmaceutical compounds. Thus, research should be devoted to the optimization of the process performance by modifying the operating parameters (when possible), and/or investigating the combination with more powerful technologies to be applied as tertiary treatment.

MBR technology has been extensively investigated for the removal of CEC, but the mechanisms have not yet been fully unravelled. Further research is needed to understand removal mechanisms of the CEC and microbiological contaminants such as ARB\&ARGs. For example, fouling layer interaction and the role of deposits on the membrane surface as potential additional barrier increasing CEC removal is needed. In addition, identification of CEC removing bacterial species and/or enzymes, unravelling optimal operating conditions, and elucidation of the metabolites produced during MBR treatment is required. These products may possess different structural characteristics compared to the parent compounds, making them toxic once they are filtered and end up in the clarified MBR effluent. Finally, cost-effective integrated MBR systems providing synergistic effects of combined technologies, should be further developed with emphasis on system optimization, scaling up, and full-scale validation. 
The removal of chemical and microbial CEC by CWs is a recent area of study, and current CWs are not able to effectively eliminate CEC from wastewater. Therefore, more research is needed to identify the feasibility for full-scale applications. The efficiency of the processes occurring in CWs depends primarily on the operation mode, design, type of substrate and the presence and type of plants. Therefore, studies should be designed to reveal the effect of each process on CEC. Only with that information one can optimize CWs design and operating parameters, consequently getting better treatment efficiency and fully supporting CWs utility. In addition, the effectiveness of the processes in the CWs can be increased by the use of hybrid systems that combine CWs of different designs in series or by combining CWs with other processes e.g. solar driven homogeneous advanced oxidation processes (e.g., sunlight mild photo Fenton, sunlight $/ \mathrm{H}_{2} \mathrm{O}_{2}$ ). As CWs have some specific prerequisites, such as large areas requirements and the fact that it can be dependent on temperature (seasonality effect), their application is site dependant.

The number of wastewater treatment plants designed using the MBBR technology as the main secondary treatment process around the world is estimated by Veolia to be between 20 and 50, mainly in Scandinavia, China and the United States. Even less studies investigated the fate of CEC throughout the process treatment at full-scale. The added value of biofilm for the elimination of CEC still needs to be investigated in laboratory scale and up-scaled to real applications. The global understanding of CEC removal pathways (including diffusion into the biofilm, hydrodynamics conditions) and regulation of bacterial communities on biofilm (through biofilm thickness) should be in the scope of new research projects. The occurrence of the highly active biomass in the biofilm in the later stages of MBBR treatment trains could be positive for the removal of recalcitrant organic CEC, but the generally achieved thin biofilm contains too little biomass to complete the CEC degradation in a realistic contact time. This experimental evidence suggests that research should aim to increase the available biomass retained in these parts of the MBBR treatment train while retaining the efficient biomass. In this paper, MBBR technology was studied as the secondary treatment. 
However, MBBR as a tertiary treatment should also be considered as an interesting advanced treatment technology for recalcitrant CEC removal.

However, regardless of the applied technology, the removal of CEC depends on the treatment conditions and the physicochemical properties of the individual compounds. Furthermore, the current knowledge suggests that the factors that rule the fate of ARB\&ARGs are complex and variable among different WWTP, making each plant a unique microbial ecosystem. Therefore, it is still difficult to assess the CEC impact onto the wastewater receiving environments, as well as the potential ways in which CEC removal can be enhanced. This highlights the need for research to maximize CEC removal by biological processes while successfully removing conventional parameters (namely, BOD, COD, nitrogen, phosphorus, etc.) to promote a safer reuse of treated wastewater.

\section{Acknowledgments}

The Authors would like to acknowledge the COST Action ES1403 NEREUS "New and emerging challenges and opportunities in wastewater reuse", supported by COST (European Cooperation in Science and Technology, www.cost.eu), for enabling the collaboration among the authors of the paper. Thank are also due to anonymous reviewers whose constructive comments helped to significantly improve this manuscript. 


\section{References}

2015/495/EU, D. (2015) Commission Implementing Decision (EU) 2015/495 of 20 March 2015 establishing a watch list of substances for Union-wide monitoring in the field of water policy pursuant to Directive 2008/105/EC of the European Parliament and of the Council, pp. 40-42.

Ahmed, M.B., Zhou, J.L., Ngo, H.H., Guo, W., Thomaidis, N.S. and Xu, J. (2017) Progress in the biological and chemical treatment technologies for emerging contaminant removal from wastewater: A critical review. Journal of Hazardous materials 323, Part A, 274-298.

Al-Jassim, N., Ansari, M.I., Harb, M. and Hong, P.Y. (2015) Removal of bacterial contaminants and antibiotic resistance genes by conventional wastewater treatment processes in Saudi Arabia: Is the treated wastewater safe to reuse for agricultural irrigation? Water Research 73, 277-290.

Alexander, J., Bollmann, A., Seitz, W. and Schwartz, T. (2015) Microbiological characterization of aquatic microbiomes targeting taxonomical marker genes and antibiotic resistance genes of opportunistic bacteria. Science of the Total Environment 512-513, 316-325.

Almeida, C.M.R., Santos, F., Ferreira, A.C.F., Gomes, C.R., Basto, M.C.P. and Mucha, A.P. (2017) Constructed wetlands for the removal of metals from livestock wastewater - Can the presence of veterinary antibiotics affect removals? Ecotoxicology and Environmental Safety 137, 143-148.

Alvarino, T., Suarez, S., Lema, J. and Omil, F. (2018) Understanding the sorption and biotransformation of organic micropollutants in innovative biological wastewater treatment technologies. Science of the Total Environment 615, 297-306.

Amin, M.M., Bina, B., Ebrahim, K., Yavari, Z. and Mohammadi, F. (2018) Biodegradation of natural and synthetic estrogens in moving bed bioreactor. Chinese Journal of Chemical Engineering 26(2), 393-399.

Andersen, H., Siegrist, H., Halling-Sørensen, B. and Ternes, T.A. (2003) Fate of Estrogens in a Municipal Sewage Treatment Plant. Environmental Science \& Technology 37(18), 4021-4026.

Andreozzi, R., Raffaele, M. and Nicklas, P. (2003) Pharmaceuticals in STP effluents and their solar photodegradation in aquatic environment. Chemosphere 50(10), 1319-1330. 
Arola, K., Hatakka, H., Mänttäri, M. and Kallioinen, M. (2017) Novel process concept alternatives for improved removal of micropollutants in wastewater treatment. Separation and Purification Technology 186(Supplement C), 333-341.

Arriaga, S., de Jonge, N., Nielsen, M.L., Andersen, H.R., Borregaard, V., Jewel, K., Ternes, T.A. and Nielsen, J.L. (2016) Evaluation of a membrane bioreactor system as post-treatment in waste water treatment for better removal of micropollutants. Water Research 107, 37-46.

Asimakopoulos, A.G., Ajibola, A., Kannan, K. and Thomaidis, N.S. (2013) Occurrence and removal efficiencies of benzotriazoles and benzothiazoles in a wastewater treatment plant in Greece. Science of the Total Environment 452, 163-171.

Auvinen, H., Havran, I., Hubau, L., Vanseveren, L., Gebhardt, W., Linnemann, V., Van Oirschot, D., Du Laing, G. and Rousseau, D.P.L. (2017) Removal of pharmaceuticals by a pilot aerated sub-surface flow constructed wetland treating municipal and hospital wastewater. Ecological Engineering 100, 157-164.

Ávila, C., Matamoros, V., Reyes-Contreras, C., Piña, B., Casado, M., Mita, L., Rivetti, C., Barata, C., García, J. and Bayona, J.M. (2014a) Attenuation of emerging organic contaminants in a hybrid constructed wetland system under different hydraulic loading rates and their associated toxicological effects in wastewater. Science of the Total Environment 470-471(0), 1272-1280.

Ávila, C., Nivala, J., Olsson, L., Kassa, K., Headley, T., Mueller, R.A., Bayona, J.M. and García, J. (2014b) Emerging organic contaminants in vertical subsurface flow constructed wetlands: Influence of media size, loading frequency and use of active aeration. Science of the Total Environment 494-495(0), 211-217.

Ávila, C., Pelissari, C., Sezerino, P., Sgroi, M., Roccaro, P. and García, J. (2017) Enhancement of total nitrogen removal through effluent recirculation and fate of PPCPs in a hybrid constructed wetland system treating urban wastewater. Science of the Total Environment 584-585, 414-425.

Ávila, C., Reyes, C., Bayona, J.M. and García, J. (2013) Emerging organic contaminant removal depending on primary treatment and operational strategy in horizontal subsurface flow constructed wetlands: Influence of redox. Water Research 47(1), 315-325. 
Barbosa, M.O., Moreira, N.F.F., Ribeiro, A.R., Pereira, M.F.R. and Silva, A.M.T. (2016) Occurrence and removal of organic micropollutants: An overview of the watch list of EU Decision 2015/495. Water Research 94, 257-279.

Barceló D, H.M.C. (2003) Trace determination of pesticides and their degradation products in water, Elsevier Science B.V. , Amsterdam.

Barceló, D., Petrovic, M. and Radjenovic, J. (2009) Treating emerging contaminants (pharmaceuticals) in wastewater and drinking water treatment plants. Technological perspectives for rational use of water resources in the Mediterranean region. CIHEAM, Bari, Italy.

Baumgarten, S., Schröder, H.F., Charwath, C., Lange, M., Beier, S. and Pinnekamp, J. (2007) Evaluation of advanced treatment technologies for the elimination of pharmaceutical compounds. Water Science and Technology 56(5), 1-8.

Ben, W., Wang, J., Cao, R., Yang, M., Zhang, Y. and Qiang, Z. (2017) Distribution of antibiotic resistance in the effluents of ten municipal wastewater treatment plants in China and the effect of treatment processes. Chemosphere 172, 392-398.

Bengtsson-Palme, J., Hammaren, R., Pal, C., Ostman, M., Bjorlenius, B., Flach, C.F., Fick, J., Kristiansson, E., Tysklind, M. and Larsson, D.G.J. (2016) Elucidating selection processes for antibiotic resistance in sewage treatment plants using metagenomics. Science of the Total Environment 572, 697-712.

Berendonk, T.U., Manaia, C.M., Merlin, C., Fatta-Kassinos, D., Cytryn, E., Walsh, F., Burgmann, H., Sorum, H., Norstrom, M., Pons, M.-N., Kreuzinger, N., Huovinen, P., Stefani, S., Schwartz, T., Kisand, V., Baquero, F. and Martinez, J.L. (2015) Tackling antibiotic resistance: the environmental framework. Nature Reviews Microbiology 13(5), 310-317.

Berglund, B., Fick, J. and Lindgren, P.-E. (2015) Urban wastewater effluent increases antibiotic resistance gene concentrations in a receiving northern European river. Environmental Toxicology and Chemistry 34(1), $192-196$. 
Berglund, B., Khan, G.A., Weisner, S.E.B., Ehde, P.M., Fick, J. and Lindgren, P.-E. (2014) Efficient removal of antibiotics in surface-flow constructed wetlands, with no observed impact on antibiotic resistance genes. Science of the Total Environment 476-477(0), 29-37.

Bernhard, M., Müller, J. and Knepper, T.P. (2006) Biodegradation of persistent polar pollutants in wastewater: Comparison of an optimised lab-scale membrane bioreactor and activated sludge treatment. Water Research 40(18), 3419-3428.

Besha, A.T., Gebreyohannes, A.Y., Tufa, R.A., Bekele, D.N., Curcio, E. and Giorno, L. (2017) Removal of emerging micropollutants by activated sludge process and membrane bioreactors and the effects of micropollutants on membrane fouling: A review. Journal of Environmental Chemical Engineering 5(3), 23952414.

Bhatia, M. and Goyal, D. (2014) Analyzing remediation potential of wastewater through wetland plants: A review. Environmental Progress and Sustainable Energy 33(1), 9-27.

Birošová, L., Mackulak, T., Bodík, I., Ryba, J., Škubák, J. and Grabic, R. (2014) Pilot study of seasonal occurrence and distribution of antibiotics and drug resistant bacteria in wastewater treatment plants in Slovakia. Science of the Total Environment 490, 440-444.

Blaak, H., Lynch, G., Italiaander, R., Hamidjaja, R.A., Schets, F.M. and de Roda Husman, A.M. (2015) Multidrug-Resistant and Extended Spectrum Beta-Lactamase-Producing Escherichia coli in Dutch Surface Water and Wastewater. Plos One 10(6), e0127752.

Bollmann, A.F., Seitz, W., Prasse, C., Lucke, T., Schulz, W. and Ternes, T. (2016) Occurrence and fate of amisulpride, sulpiride, and lamotrigine in municipal wastewater treatment plants with biological treatment and ozonation. Journal of Hazardous materials 320, 204-215.

Bolzonella, D., Fatone, F., di Fabio, S. and Cecchi, F. (2010) Application of membrane bioreactor technology for wastewater treatment and reuse in the Mediterranean region: Focusing on removal efficiency of nonconventional pollutants. Journal of Environmental Management 91(12), 2424-2431. 
Botero-Coy, A.M., Martínez-Pachón, D., Boix, C., Rincón, R.J., Castillo, N., Arias-Marín, L.P., Manrique-Losada, L., Torres-Palma, R., Moncayo-Lasso, A. and Hernández, F. (2018) 'An investigation into the occurrence and removal of pharmaceuticals in Colombian wastewater'. Science of the Total Environment $642,842-853$.

Bui, T.X. and Choi, H. (2010) Influence of ionic strength, anions, cations, and natural organic matter on the adsorption of pharmaceuticals to silica. Chemosphere 80(7), 681-686.

Bui, X.T., Vo, T.P.T., Ngo, H.H., Guo, W.S. and Nguyen, T.T. (2016) Multicriteria assessment of advanced treatment technologies for micropollutants removal at large-scale applications. Science of the Total Environment 563-564, 1050-1067.

Buser, H.-R., Poiger, T. and Müller, M. (1998) Occurrence and fate of the pharmaceutical drug diclofenac in surface waters: Rapid photodegradation in a lake. Environ. Sci. Technol 32(22), 3449-3456.

Cahill, M.G., Caprioli, G., Stack, M., Vittori, S. and James, K.J. (2011) Semi-automated liquid chromatographymass spectrometry (LC-MS/MS) method for basic pesticides in wastewater effluents. Anal Bioanal Chem 400(2), 587-594

Calderón-Preciado, D., Matamoros, V., Savé, R., Muñoz, P., Biel, C. and Bayona, J.M. (2013) Uptake of microcontaminants by crops irrigated with reclaimed water and groundwater under real field greenhouse conditions. Environmental Science and Pollution Research 20(6), 3629-3638.

Camacho-Muñoz, D., Martín, J., Santos, J.L., Aparicio, I. and Alonso, E. (2012) Effectiveness of Conventional and Low-Cost Wastewater Treatments in the Removal of Pharmaceutically Active Compounds. Water, Air, \& Soil Pollution 223(5), 2611-2621.

Carranza-Diaz, O., Schultze-Nobre, L., Moeder, M., Nivala, J., Kuschk, P. and Koeser, H. (2014) Removal of selected organic micropollutants in planted and unplanted pilot-scale horizontal flow constructed wetlands under conditions of high organic load. Ecological Engineering 71, 234-245.

Cartagena, P., El Kaddouri, M., Cases, V., Trapote, A. and Prats, D. (2013) Reduction of emerging micropollutants, organic matter, nutrients and salinity from real wastewater by combined MBR-NF/RO treatment. Separation and Purification Technology 110(0), 132-143. 
Carvalho, I.T. and Santos, L. (2016) Antibiotics in the aquatic environments: A review of the European scenario. Environment International 94, 736-757.

Carvalho, P., Basto, M.C., Almeida, C.M. and Brix, H. (2014) A review of plant-pharmaceutical interactions: from uptake and effects in crop plants to phytoremediation in constructed wetlands. Environmental Science and Pollution Research, 1-35.

Cases, V., Alonso, V., Argandoña, V., Rodriguez, M. and Prats, D. (2011) Endocrine disrupting compounds: A comparison of removal between conventional activated sludge and membrane bioreactors. Desalination $272(1-3), 240-245$.

Castiglioni, S., Bagnati, R., Fanelli, R., Pomati, F., Calamari, D. and Zuccato, E. (2006) Removal of Pharmaceuticals in Sewage Treatment Plants in Italy. Environmental Science \& Technology 40(1), 357-363.

Cecconet, D., Molognoni, D., Callegari, A. and Capodaglio, A.G. (2017) Biological combination processes for efficient removal of pharmaceutically active compounds from wastewater: A review and future perspectives. Journal of Environmental Chemical Engineering 5(4), 3590-3603.

Chen, H. and Zhang, M. (2013) Occurrence and removal of antibiotic resistance genes in municipal wastewater and rural domestic sewage treatment systems in eastern China. Environ Int 55, 9-14.

Chen, J., Liu, Y.S., Su, H.C., Ying, G.G., Liu, F., Liu, S.S., He, L.Y., Chen, Z.F., Yang, Y.Q. and Chen, F.R. (2015) Removal of antibiotics and antibiotic resistance genes in rural wastewater by an integrated constructed wetland. Environ Sci Pollut Res Int 22(3), 1794-1803.

Chen, J., Ying, G.-G., Wei, X.-D., Liu, Y.-S., Liu, S.-S., Hu, L.-X., He, L.-Y., Chen, Z.-F., Chen, F.-R. and Yang, Y.-Q. (2016) Removal of antibiotics and antibiotic resistance genes from domestic sewage by constructed wetlands: Effect of flow configuration and plant species. Science of the Total Environment 571, 974-982.

Christgen, B., Yang, Y., Ahammad, S.Z., Li, B., Rodriquez, D.C., Zhang, T. and Graham, D.W. (2015) Metagenomics shows that low-energy anaerobic-aerobic treatment reactors reduce antibiotic resistance gene levels from domestic wastewater. Environmental Science and Technology 49(4), 2577-2584. 
Christou, A., Karaolia, P., Hapeshi, E., Michael, C. and Fatta-Kassinos, D. (2017) Long-term wastewater irrigation of vegetables in real agricultural systems: Concentration of pharmaceuticals in soil, uptake and bioaccumulation in tomato fruits and human health risk assessment. Water Research 109, 24-34.

Christou, A., Michael, C., Fatta-Kassinos, D. and Fotopoulos, V. (2018) Can the pharmaceutically active compounds released in agroecosystems be considered as emerging plant stressors? Environment International 114, 360-364.

Cirja, M., Ivashechkin, P., Schäffer, A. and Corvini, P.F.X. (2007) Factors affecting the removal of organic micropollutants from wastewater in conventional treatment plants (CTP) and membrane bioreactors (MBR). Reviews in Environmental Science and Bio/Technology 7(1), 61-78.

Clara, M., Kreuzinger, N., Strenn, B., Gans, O. and Kroiss, H. (2005a) The solids retention time-a suitable design parameter to evaluate the capacity of wastewater treatment plants to remove micropollutants. Water Research 39(1), 97-106.

Clara, M., Strenn, B., Ausserleitner, M. and Kreuzinger, N. (2004) Comparison of the behaviour of selected micropollutants in a membrane bioreactor and a conventional wastewater treatment plant. Water Science and Technology 50(5), 29-36.

Clara, M., Strenn, B., Gans, O., Martinez, E., Kreuzinger, N. and Kroiss, H. (2005b) Removal of selected pharmaceuticals, fragrances and endocrine disrupting compounds in a membrane bioreactor and conventional wastewater treatment plants. Water Research 39(19), 4797-4807.

Clouzot, L., Roche, N. and Marrot, B. (2011) Effect of membrane bioreactor configurations on sludge structure and microbial activity. Bioresource Technology 102(2), 975-981.

Coleman, H.M., Troester, M., Khan, S.J., McDonald, J.A., Watkins, G. and Stuetz, R.M. (2009) Assessment of trace organic chemical removal by a membrane bioreactor using gas chromatography/mass spectrometry and a yeast screen bioassay. Environmental Toxicology and Chemistry 28(12), 2537-2545.

Conkle, J., Lattao, C., White, J. and Cook, R. (2010) Competitive sorption and desorption behavior for three fluoroquinolone antibiotics in a wastewater treatment wetland soil. Chemosphere 80(11), 1353-1359. 
Conte, D., Palmeiro, J.K., da Silva Nogueira, K., de Lima, T.M., Cardoso, M.A., Pontarolo, R., Degaut Pontes, F.L. and Dalla-Costa, L.M. (2017) Characterization of CTX-M enzymes, quinolone resistance determinants, and antimicrobial residues from hospital sewage, wastewater treatment plant, and river water. Ecotoxicology and Environment Safety 136, 62-69.

Corominas, L., Foley, J., Guest, J.S., Hospido, A., Larsen, H.F., Morera, S. and Shaw, A. (2013) Life cycle assessment applied to wastewater treatment: State of the art. Water Research 47(15), 5480-5492.

Cristale, J., Ramos, D.D., Dantas, R.F., Machulek Junior, A., Lacorte, S., Sans, C. and Esplugas, S. (2016) Can activated sludge treatments and advanced oxidation processes remove organophosphorus flame retardants? Environmental Research 144(Pt A), 11-18.

Dai, Y.-n., A, D., Yang, Y., Tam, N.F.-Y., Tai, Y.-P. and Tang, X.-Y. (2016) Factors Affecting Behavior of Phenolic Endocrine Disruptors, Estrone and Estradiol, in Constructed Wetlands for Domestic Sewage Treatment. Environmental Science \& Technology 50(21), 11844-11852.

Dan, A., Yang, Y., Dai, Y.-n., Chen, C.-x., Wang, S.-y. and Tao, R. (2013) Removal and factors influencing removal of sulfonamides and trimethoprim from domestic sewage in constructed wetlands. Bioresource Technology 146(Supplement C), 363-370.

de Cazes, M., Abejón, R., Belleville, M.-P. and Sanchez-Marcano, J. (2014) Membrane Bioprocesses for Pharmaceutical Micropollutant Removal from Waters. Membranes 4(4), 692.

De Guzman, J.A. (2016) Hexabromocyclododecane in municipal wastewater treatment plant: Occurrence, fate and potential environmental risks. 5th International Conference on Measurement, Instrumentation and Automation (ICMIA 2016), Shenzhen, China, .

Dialynas, E. and Diamadopoulos, E. (2012) The effect of biomass adsorption on the removal of selected pharmaceutical compounds in an immersed membrane bioreactor system. Journal of Chemical Technology \& Biotechnology 87(2), 232-237.

Díaz-Cruz, M.S. and Barceló, D. (2015) Personal Care Products in the Aquatic Environment, Springer. 
Dolar, D., Gros, M., Rodriguez-Mozaz, S., Moreno, J., Comas, J., Rodriguez-Roda, I. and Barceló, D. (2012) Removal of emerging contaminants from municipal wastewater with an integrated membrane system, MBRRO. Journal of Hazardous materials 239-240, 64-69.

Dordio, A., Carvalho, A.J.P., Teixeira, D.M., Dias, C.B. and Pinto, A.P. (2010) Removal of pharmaceuticals in microcosm constructed wetlands using Typha spp. and LECA. Bioresource Technology 101(3), 886-892.

Dordio, A.V. and Carvalho, A.J.P. (2013) Organic xenobiotics removal in constructed wetlands, with emphasis on the importance of the support matrix. Journal of Hazardous materials 252-253, 272-292.

Dordio, A.V., Duarte, C., Barreiros, M., Carvalho, A.J.P., Pinto, A. and da Costa, C.T. (2009) Toxicity and removal efficiency of pharmaceutical metabolite clofibric acid by Typha spp. - Potential use for phytoremediation? Bioresource Technology 100(3), 1156-1161.

Dordio, A.V., Teimão, J., Ramalho, I., Carvalho, A.J.P. and Candeias, A.J.E. (2007) Selection of a support matrix for the removal of some phenoxyacetic compounds in constructed wetlands systems. Science of the Total Environment 380(1-3), 237-246.

Du, B., Price, A.E., Scott, W.C., Kristofco, L.A., Ramirez, A.J., Chambliss, C.K., Yelderman, J.C. and Brooks, B.W. (2014) Comparison of contaminants of emerging concern removal, discharge, and water quality hazards among centralized and on-site wastewater treatment system effluents receiving common wastewater influent. Science of the Total Environment 466-467, 976-984.

Du, J., Geng, J., Ren, H., Ding, L., Xu, K. and Zhang, Y. (2015) Variation of antibiotic resistance genes in municipal wastewater treatment plant with A(2)O-MBR system. Environ Sci Pollut Res Int 22(5), 3715-3726. Eggen, T., Asp, T.N., Grave, K. and Hormazabal, V. (2011) Uptake and translocation of metformin, ciprofloxacin and narasin in forage- and crop plants. Chemosphere 85(1), 26-33.

Eggen, T. and Vogelsang, C. (2015) Comprehensive Analytical Chemistry. Eddy, Y.Z. (ed), pp. 245-294, Elsevier.

Ekpeghere, K.I., Kim, U.J., O, S.H., Kim, H.Y. and Oh, J.E. (2016) Distribution and seasonal occurrence of UV filters in rivers and wastewater treatment plants in Korea. Science of the Total Environment 542(Pt A), 121128. 
Ekpeghere, K.I., Sim, W.-J., Lee, H.-J. and Oh, J.-E. (2018) Occurrence and distribution of carbamazepine, nicotine, estrogenic compounds, and their transformation products in wastewater from various treatment plants and the aquatic environment. Science of the Total Environment 640-641, 1015-1023.

Escola Casas, M., Chhetri, R.K., Ooi, G., Hansen, K.M., Litty, K., Christensson, M., Kragelund, C., Andersen, H.R. and Bester, K. (2015a) Biodegradation of pharmaceuticals in hospital wastewater by staged Moving Bed Biofilm Reactors (MBBR). Water Research 83, 293-302.

Escola Casas, M., Chhetri, R.K., Ooi, G., Hansen, K.M.S., Litty, K., Christensson, M., Kragelund, C., Andersen, H.R. and Bester, K. (2015b) Biodegradation of pharmaceuticals in hospital wastewater by a hybrid biofilm and activated sludge system (Hybas). Science of the Total Environment 530-531, 383-392.

Falas, P., Longree, P., la Cour Jansen, J., Siegrist, H., Hollender, J. and Joss, A. (2013) Micropollutant removal by attached and suspended growth in a hybrid biofilm-activated sludge process. Water Research $47(13)$, 4498-4506.

Fatone, F. (2010) Xenobiotics in the Urban Water Cycle: Mass Flows, Environmental Processes, Mitigation and Treatment Strategies. Fatta-Kassinos, D., Bester, K. and Kümmerer, K. (eds), pp. 339-354, Springer Netherlands, Dordrecht.

Felis, E., Sochacki, A. and Magiera, S. (2016) Degradation of benzotriazole and benzothiazole in treatment wetlands and by artificial sunlight. Water Research 104, 441-448.

Fenu, A., Donckels, B.M.R., Beffa, T., Bemfohr, C. and Weemaes, M. (2015) Evaluating the application of Microbacterium sp. strain BR1 for the removal of sulfamethoxazole in full-scale membrane bioreactors. Water Science and Technology 72(10), 1754-1761.

Fernandez-Fontaina, E., Omil, F., Lema, J.M. and Carballa, M. (2012) Influence of nitrifying conditions on the biodegradation and sorption of emerging micropollutants. Water Research 46(16), 5434-5444.

Ferrari, B.t., Paxéus, N., Giudice, R.L., Pollio, A. and Garric, J. (2003) Ecotoxicological impact of pharmaceuticals found in treated wastewaters: study of carbamazepine, clofibric acid, and diclofenac. Ecotoxicology and Environmental Safety 55(3), 359-370. 
Garcia-Rodríguez, A., Matamoros, V., Fontàs, C. and Salvadó, V. (2014) The ability of biologically based wastewater treatment systems to remove emerging organic contaminants-a review. Environmental Science and Pollution Research, 1-21.

García Galán, M.J., Díaz-Cruz, M.S. and Barceló, D. (2012) Removal of sulfonamide antibiotics upon conventional activated sludge and advanced membrane bioreactor treatment. Analytical and Bioanalytical Chemistry 404(5), 1505-1515.

García, M., Soto, F., González, J.M. and Bécares, E. (2008) A comparison of bacterial removal efficiencies in constructed wetlands and algae-based systems. Ecological Engineering 32(3), 238-243.

Gerrity, D., Pisarenko, A.N., Marti, E., Trenholm, R.A., Gerringer, F., Reungoat, J. and Dickenson, E. (2015) Nitrosamines in pilot-scale and full-scale wastewater treatment plants with ozonation. Water Research 72 , 251-261.

Ghosh, G.C., Okuda, T., Yamashita, N. and Tanaka, H. (2009) Occurrence and elimination of antibiotics at four sewage treatment plants in Japan and their effects on bacterial ammonia oxidation. Water Science and Technology 59(4), 779-786.

Gobel, A., Thomsen, A., McArdell, C.S., Joss, A. and Giger, W. (2005) Occurrence and sorption behavior of sulfonamides, macrolides, and trimethoprim in activated sludge treatment. Environmental Science and Technology 39(11), 3981-3989.

Goldstein, M., Shenker, M. and Chefetz, B. (2014) Insights into the Uptake Processes of Wastewater-Borne Pharmaceuticals by Vegetables. Environmental Science \& Technology 48(10), 5593-5600.

González, S., Müller, J., Petrovic, M., Barceló, D. and Knepper, T.P. (2006) Biodegradation studies of selected priority acidic pesticides and diclofenac in different bioreactors. Environmental Pollution 144(3), 926-932.

Gorito, A.M., Ribeiro, A.R., Almeida, C.M.R. and Silva, A.M.T. (2017) A review on the application of constructed wetlands for the removal of priority substances and contaminants of emerging concern listed in recently launched EU legislation. Environmental Pollution 227, 428-443. 
Grandclément, C., Seyssiecq, I., Piram, A., Wong-Wah-Chung, P., Vanot, G., Tiliacos, N., Roche, N. and Doumenq, P. (2017) From the conventional biological wastewater treatment to hybrid processes, the evaluation of organic micropollutant removal: A review. Water Research 111, 297-317.

Gros, M., Petrovic, M. and Barcelo, D. (2006) Development of a multi-residue analytical methodology based on liquid chromatography-tandem mass spectrometry (LC-MS/MS) for screening and trace level determination of pharmaceuticals in surface and wastewaters. Talanta 70(4), 678-690.

Gros, M., Petrović, M., Ginebreda, A. and Barceló, D. (2010) Removal of pharmaceuticals during wastewater treatment and environmental risk assessment using hazard indexes. Environment International 36(1), 15-26. Guerra, P., Kim, M., Shah, A., Alaee, M. and Smyth, S.A. (2014) Occurrence and fate of antibiotic, analgesic/anti-inflammatory, and antifungal compounds in five wastewater treatment processes. Science of the Total Environment 473-474, 235-243.

Guittonny-Philippe, A., Petit, M.-E., Masotti, V., Monnier, Y., Malleret, L., Coulomb, B., Combroux, I., Baumberger, T., Viglione, J. and Laffont-Schwob, I. (2015) Selection of wild macrophytes for use in constructed wetlands for phytoremediation of contaminant mixtures. Journal of Environmental Management 147, 108-123.

Göbel, A., McArdell, C.S., Joss, A., Siegrist, H. and Giger, W. (2007) Fate of sulfonamides, macrolides, and trimethoprim in different wastewater treatment technologies. Science of the Total Environment 372(2-3), $361-371$

Halden, R.U. and Paull, D.H. (2005) Co-occurrence of triclocarban and triclosan in US water resources. Environmental Science \& Technology 39(6), 1420-1426.

Hamza, R.A., lorhemen, O.T. and Tay, J.H. (2016) Occurrence, impacts and removal of emerging substances of concern from wastewater. Environmental Technology \& Innovation 5, 161-175.

He, K., Soares, A.D., Adejumo, H., McDiarmid, M., Squibb, K. and Blaney, L. (2015) Detection of a wide variety of human and veterinary fluoroquinolone antibiotics in municipal wastewater and wastewater-impacted surface water. Journal of Pharmaceutical and Biomedical Analysis 106, 136-143. 
He, Y.-j., Chen, W., Zheng, X.-y., Wang, X.-n. and Huang, X. (2013) Fate and removal of typical pharmaceuticals and personal care products by three different treatment processes. Science of the Total Environment 447(0), 248-254.

He, Y., Langenhoff, A., Sutton, n., Rijnaarts, H., Blokland, M., Chen, F., Huberand, C. and Schröder, P. (2017) Metabolism of Ibuprofen by Phragmites australis: Uptake and Phytodegradation. Environmental Science \& Technology 51(8), 4576-4584.

He, Y., Sutton, N.B., Rijnaarts, H.H.H. and Langenhoff, A.A.M. (2016) Degradation of pharmaceuticals in wastewater using immobilized TiO2 photocatalysis under simulated solar irradiation. Applied Catalysis B: Environmental 182, 132-141.

Hernando, M.D., Petrovic, M., Radjenovic, J., Fernández-Alba, A.R. and Barceló, D. (2007) Comprehensive Analytical Chemistry. Petrović, M. and Barceló, D. (eds), pp. 451-474, Elsevier.

Hijosa-Valsero, M., Fink, G., Schlüsener, M.P., Sidrach-Cardona, R., Martín-Villacorta, J., Ternes, T. and Bécares, E. (2011a) Removal of antibiotics from urban wastewater by constructed wetland optimization. Chemosphere 83(5), 713-719.

Hijosa-Valsero, M., Matamoros, V., Martín-Villacorta, J., Bécares, E. and Bayona, J.M. (2010a) Assessment of full-scale natural systems for the removal of PPCPs from wastewater in small communities. Water Research 44(5), 1429-1439.

Hijosa-Valsero, M., Matamoros, V., Sidrach-Cardona, R., Martín-Villacorta, J., Bécares, E. and Bayona, J.M. (2010b) Comprehensive assessment of the design configuration of constructed wetlands for the removal of pharmaceuticals and personal care products from urban wastewaters. Water Research 44(12), 3669-3678. Hijosa-Valsero, M., Reyes-Contreras, C., Domínguez, C., Bécares, E. and Bayona, J.M. (2016) Behaviour of pharmaceuticals and personal care products in constructed wetland compartments: Influent, effluent, pore water, substrate and plant roots. Chemosphere 145, 508-517.

Hijosa-Valsero, M., Sidrach-Cardona, R. and Bécares, E. (2012) Comparison of interannual removal variation of various constructed wetland types. Science of the Total Environment 430, 174-183. 
Hijosa-Valsero, M., Sidrach-Cardona, R., Martín-Villacorta, J., Cruz Valsero-Blanco, M., Bayona, J.M. and Bécares, E. (2011b) Statistical modelling of organic matter and emerging pollutants removal in constructed wetlands. Bioresource Technology 102(8), 4981-4988.

Holbrook, R.D., Novak, J.T., Grizzard, T.J. and Love, N.G. (2002) Estrogen Receptor Agonist Fate during Wastewater and Biosolids Treatment Processes: A Mass Balance Analysis. Environmental Science \& Technology 36(21), 4533-4539.

Hsieh, C.Y., Liaw, E.T. and Fan, K.M. (2015) Removal of veterinary antibiotics, alkylphenolic compounds, and estrogens from the Wuluo constructed wetland in southern Taiwan. Journal of Environmental Science and Health, Part A 50(2), 151-160.

Huang, X., Liu, C., Li, K., Su, J., Zhu, G. and Liu, L. (2015) Performance of vertical up-flow constructed wetlands on swine wastewater containing tetracyclines and tet genes. Water Research 70, 109-117.

Huang, X., Zheng, J., Liu, C., Liu, L., Liu, Y. and Fan, H. (2017) Removal of antibiotics and resistance genes from swine wastewater using vertical flow constructed wetlands: Effect of hydraulic flow direction and substrate type. Chemical Engineering Journal 308, 692-699.

Imfeld, G., Braeckevelt, M., Kuschk, P. and Richnow, H.H. (2009) Monitoring and assessing processes of organic chemicals removal in constructed wetlands. Chemosphere 74(3), 349-362.

Jones, O.A.H., Green, P.G., Voulvoulis, N. and Lester, J.N. (2007) Questioning the Excessive Use of Advanced Treatment to Remove Organic Micropollutants from Wastewater. Environmental Science \& Technology 41(14), 5085-5089.

Jones, S.M., Chowdhury, Z.K. and Watts, M.J. (2017) A taxonomy of chemicals of emerging concern based on observed fate at water resource recovery facilities. Chemosphere 170, 153-160.

Joss, A., Andersen, H., Ternes, T., Richle, P.R. and Siegrist, H. (2004) Removal of Estrogens in Municipal Wastewater Treatment under Aerobic and Anaerobic Conditions: Consequences for Plant Optimization. Environmental Science \& Technology 38(11), 3047-3055.

Joss, A., Keller, E., Alder, A.C., Göbel, A., McArdell, C.S., Ternes, T. and Siegrist, H. (2005) Removal of pharmaceuticals and fragrances in biological wastewater treatment. Water Research 39(14), 3139-3152. 
Kantiani, L., Farré, M., Asperger, D., Rubio, F., González, S., López de Alda, M.J., Petrović, M., Shelver, W.L. and Barceló, D. (2008) Triclosan and methyl-triclosan monitoring study in the northeast of Spain using a magnetic particle enzyme immunoassay and confirmatory analysis by gas chromatography-mass spectrometry. Journal of Hydrology 361(1-2), 1-9.

Karkman, A., Johnson, T.A., Lyra, C., Stedtfeld, R.D., Tamminen, M., Tiedje, J.M. and Virta, M. (2016) Highthroughput quantification of antibiotic resistance genes from an urban wastewater treatment plant. FEMS Microbiology Ecology 92(3).

Kim, M., Guerra, P., Shah, A., Parsa, M., Alaee, M. and Smyth, S.A. (2014) Removal of pharmaceuticals and personal care products in a membrane bioreactor wastewater treatment plant. Water Science and Technology 69(11), 2221-2229.

Kim, S., Chu, K.H., Al-Hamadani, Y.A.J., Park, C.M., Jang, M., Kim, D.-H., Yu, M., Heo, J. and Yoon, Y. (2018) Removal of contaminants of emerging concern by membranes in water and wastewater: A review. Chemical Engineering Journal 335, 896-914.

Kim, S.D., Cho, J., Kim, I.S., Vanderford, B.J. and Snyder, S.A. (2007) Occurrence and removal of pharmaceuticals and endocrine disruptors in South Korean surface, drinking, and waste waters. Water Research 41(5), 1013-1021.

Kim, S.K., Im, J.K., Kang, Y.M., Jung, S.Y., Kho, Y.L. and Zoh, K.D. (2012) Wastewater treatment plants (WWTPs)-derived national discharge loads of perfluorinated compounds (PFCs). Journal of Hazardous materials 201-202, 82-91.

Kim, U.J., Lee, I.S. and Oh, J.E. (2016) Occurrence, removal and release characteristics of dissolved brominated flame retardants and their potential metabolites in various kinds of wastewater. Environmental Pollution 218, 551-557.

Kimura, K., Hara, H. and Watanabe, Y. (2005) Removal of pharmaceutical compounds by submerged membrane bioreactors (MBRs). Desalination 178(1-3), 135-140. 
Kimura, K., Hara, H. and Watanabe, Y. (2007) Elimination of Selected Acidic Pharmaceuticals from Municipal Wastewater by an Activated Sludge System and Membrane Bioreactors. Environmental Science \& Technology 41(10), 3708-3714.

Klaper, R. and Welch, L. (2011) Emerging contaminant threats and the Great Lakes: existing science, estimating relative risk and determining policies., Alliance for the Great Lakes. https://www.greatlakes.org/. Accessed 20 April 2018.

Kock-Schulmeyer, M., Villagrasa, M., Lopez de Alda, M., Cespedes-Sanchez, R., Ventura, F. and Barcelo, D. (2013) Occurrence and behavior of pesticides in wastewater treatment plants and their environmental impact. Science of the Total Environment 458-460, 466-476.

Komesli, O.T., Muz, M., Ak, M.S., Bakırdere, S. and Gokcay, C.F. (2015) Occurrence, fate and removal of endocrine disrupting compounds (EDCs) in Turkish wastewater treatment plants. Chemical Engineering Journal $277,202-208$.

Kosma, C.I., Lambropoulou, D.A. and Albanis, T.A. (2015) Occurrence of metformin and guanylurea in wastewaters in Greece. 14th International Conference on Environmental Science and Technology, Rhodes, Greece.

Kotchen, M., Kallaos, J., Wheeler, K., Wong, C. and Zahller, M. (2009) Pharmaceuticals in wastewater: Behavior, preferences, and willingness to pay for a disposal program. Journal of Environmental Management 90(3), 1476-1482.

Kotlarska, E., Łuczkiewicz, A., Pisowacka, M. and Burzyński, A. (2015) Antibiotic resistance and prevalence of class 1 and 2 integrons in Escherichia coli isolated from two wastewater treatment plants, and their receiving waters (Gulf of Gdansk, Baltic Sea, Poland). Environmental Science and Pollution Research 22(3), 2018-2030. Kreuzinger, N., Clara, M., Strenn, B. and Kroiss, H. (2004) Relevance of the sludge retention time (SRT) as design criteria for wastewater treatment plants for the removal of endocrine disruptors and pharmaceuticals from wastewater. Water Science and Technology 50(5), 149-156. 
Krzeminski, P., Leverette, L., Malamis, S. and Katsou, E. (2017) Membrane bioreactors - A review on recent developments in energy reduction, fouling control, novel configurations, LCA and market prospects. Journal of Membrane Science 527, 207-227.

Kumar, A.K., Chiranjeevi, P., Mohanakrishna, G. and Mohan, S.V. (2011) Natural attenuation of endocrinedisrupting estrogens in an ecologically engineered treatment system (EETS) designed with floating, submerged and emergent macrophytes. Ecological Engineering 37(10), 1555-1562.

Laht, M., Karkman, A., Voolaid, V., Ritz, C., Tenson, T., Virta, M. and Kisand, V. (2014) Abundances of tetracycline, sulphonamide and beta-lactam antibiotic resistance genes in conventional wastewater treatment plants (WWTPs) with different waste load. Plos One 9(8), e103705.

Le-Minh, N., Coleman, H.M., Khan, S.J., van Luer, Y., Trang, T.T.T., Watkins, G. and Stuetz, R.M. (2010) The application of membrane bioreactors as decentralised systems for removal of endocrine disrupting chemicals and pharmaceuticals. Water Science and Technology 61(5), 1081-1088.

Lee, J., Lee, B.C., Ra, J.S., Cho, J., Kim, I.S., Chang, N.I., Kim, H.K. and Kim, S.D. (2008) Comparison of the removal efficiency of endocrine disrupting compounds in pilot scale sewage treatment processes. Chemosphere 71(8), 1582-1592.

Leung, H.W., Minh, T.B., Murphy, M.B., Lam, J.C.W., So, M.K., Martin, M., Lam, P.K.S. and Richardson, B.J. (2012) Distribution, fate and risk assessment of antibiotics in sewage treatment plants in Hong Kong, South China. Environment International 42, 1-9.

Li, C., Cabassud, C. and Guigui, C. (2015) Evaluation of membrane bioreactor on removal of pharmaceutical micropollutants: a review. Desalination and Water Treatment 55(4), 845-858.

Li, J., Cheng, W., Xu, L., Jiao, Y., Baig, S.A. and Chen, H. (2016) Occurrence and removal of antibiotics and the corresponding resistance genes in wastewater treatment plants: effluents' influence to downstream water environment. Environ Sci Pollut Res Int 23(7), 6826-6835.

Li, J., Cheng, W., Xu, L., Strong, P.J. and Chen, H. (2014a) Antibiotic-resistant genes and antibiotic-resistant bacteria in the effluent of urban residential areas, hospitals, and a municipal wastewater treatment plant system. Environmental Science and Pollution Research 22(6), 4587-4596. 
Li, Y., Zhu, G., Ng, W.J. and Tan, S.K. (2014b) A review on removing pharmaceutical contaminants from wastewater by constructed wetlands: Design, performance and mechanism. Science of the Total Environment 468-469, 908-932.

Lin, A.Y., Panchangam, S.C. and Ciou, P.S. (2010) High levels of perfluorochemicals in Taiwan's wastewater treatment plants and downstream rivers pose great risk to local aquatic ecosystems. Chemosphere $80(10)$, $1167-1174$.

Lindstrom, A., Buerge, I.J., Poiger, T., Bergqvist, P.A., Muller, M.D. and Buser, H.R. (2002) Occurrence and environmental behavior of the bactericide triclosan and its methyl derivative in surface waters and in wastewater. Environmental Science and Technology 36(11), 2322-2329.

Lipp, P., Groß, H.-J. and Tiehm, A. (2012) Improved elimination of organic micropollutants by a process combination of membrane bioreactor (MBR) and powdered activated carbon (PAC). Desalination and Water Treatment 42(1-3), 65-72.

Liu, L., Liu, C., Zheng, J., Huang, X., Wang, Z., Liu, Y. and Zhu, G. (2013) Elimination of veterinary antibiotics and antibiotic resistance genes from swine wastewater in the vertical flow constructed wetlands. Chemosphere 91(8), 1088-1093.

Liu, R., Song, S., Lin, Y., Ruan, T. and Jiang, G. (2015) Occurrence of synthetic phenolic antioxidants and major metabolites in municipal sewage sludge in China. Environmental Science and Technology 49(4), 2073-2080. Liu, Y.S., Ying, G.G., Shareef, A. and Kookana, R.S. (2012) Occurrence and removal of benzotriazoles and ultraviolet filters in a municipal wastewater treatment plant. Environmental Pollution 165, 225-232.

Loganathan, B., Phillips, M., Mowery, H. and Jones-Lepp, T.L. (2009) Contamination profiles and mass loadings of macrolide antibiotics and illicit drugs from a small urban wastewater treatment plant. Chemosphere 75(1), 70-77.

Logar, I., Brouwer, R., Maurer, M. and Ort, C. (2014) Cost-Benefit Analysis of the Swiss National Policy on Reducing Micropollutants in Treated Wastewater. Environmental Science \& Technology 48(21), 1250012508. 
Loos, R., Carvalho, R., António, D.C., Comero, S., Locoro, G., Tavazzi, S., Paracchini, B., Ghiani, M., Lettieri, T., Blaha, L., Jarosova, B., Voorspoels, S., Servaes, K., Haglund, P., Fick, J., Lindberg, R.H., Schwesig, D. and Gawlik, B.M. (2013) EU-wide monitoring survey on emerging polar organic contaminants in wastewater treatment plant effluents. Water Research 47(17), 6475-6487.

Lopes, T.R., Costa, I.L., Periotto, F. and Pletsch, A.L. (2016) Antibiotic resistance inE. coliisolated in effluent from a wastewater treatment plant and sediments in receiver body. International Journal of River Basin Management 14(4), 441-445.

Luo, Y., Guo, W., Ngo, H.H., Nghiem, L.D., Hai, F.I., Zhang, J., Liang, S. and Wang, X.C. (2014) A review on the occurrence of micropollutants in the aquatic environment and their fate and removal during wastewater treatment. Science of the Total Environment 473-474(0), 619-641.

Luo, Y., Jiang, Q., Ngo, H.H., Nghiem, L.D., Hai, F.I., Price, W.E., Wang, J. and Guo, W. (2015) Evaluation of micropollutant removal and fouling reduction in a hybrid moving bed biofilm reactor-membrane bioreactor system. Bioresource Technology 191, 355-359.

Ma, R. and Shih, K. (2010) Perfluorochemicals in wastewater treatment plants and sediments in Hong Kong. Environmental Pollution 158(5), 1354-1362.

Mahabali, S. and Spanoghe, P. (2013) Mitigation of Two Insecticides by Wetland Plants: Feasibility Study for the Treatment of Agricultural Runoff in Suriname (South America). Water, Air, \& Soil Pollution 225(1), 1771. Malchi, T., Maor, Y., Tadmor, G., Shenker, M. and Chefetz, B. (2014) Irrigation of Root Vegetables with Treated Wastewater: Evaluating Uptake of Pharmaceuticals and the Associated Human Health Risks. Environmental Science \& Technology 48(16), 9325-9333.

Malpei, F., Bouju, H., Buttiglieri, G., Castiglioni, S., Colia, S., Mazzini, R. and Zuccato, E. (2012) Pharmaceutical active compounds fate and removal in Milan Nosedo WWTP: results of a 4 years research at full and pilot scale. International Symposium of Sanitary and Environmental Engineering (SIDISA 2012), Milan, Italy.

Mamo, J., Insa, S., Monclús, H., Rodríguez-Roda, I., Comas, J., Barceló, D. and Farré, M.J. (2016) Fate of NDMA precursors through an MBR-NF pilot plant for urban wastewater reclamation and the effect of changing aeration conditions. Water Research 102, 383-393. 
Manaia, C.M., Macedo, G., Fatta-Kassinos, D. and Nunes, O.C. (2016) Antibiotic resistance in urban aquatic environments: can it be controlled? Applied Microbiology and Biotechnology 100(4), 1543-1557.

Mao, D., Yu, S., Rysz, M., Luo, Y., Yang, F., Li, F., Hou, J., Mu, Q. and Alvarez, P.J. (2015) Prevalence and proliferation of antibiotic resistance genes in two municipal wastewater treatment plants. Water Research $85,458-466$.

Margot, J., Kienle, C., Magnet, A., Weil, M., Rossi, L., de Alencastro, L.F., Abegglen, C., Thonney, D., Chevre, N., Scharer, M. and Barry, D.A. (2013) Treatment of micropollutants in municipal wastewater: Ozone or powdered activated carbon? Science of the Total Environment 461, 480-498.

Matamoros, V., Arias, C., Brix, H. and Bayona, J.M. (2007) Removal of Pharmaceuticals and Personal Care Products (PPCPs) from Urban Wastewater in a Pilot Vertical Flow Constructed Wetland and a Sand Filter. Environmental Science \& Technology 41(23), 8171-8177.

Matamoros, V., Arias, C., Brix, H. and Bayona, J.M. (2009) Preliminary screening of small-scale domestic wastewater treatment systems for removal of pharmaceutical and personal care products. Water Research 43(1), 55-62.

Matamoros, V. and Bayona, J.M. (2006) Elimination of Pharmaceuticals and Personal Care Products in Subsurface Flow Constructed Wetlands. Environmental Science \& Technology 40(18), 5811-5816.

Matamoros, V., García, J. and Bayona, J.M. (2005) Behavior of Selected Pharmaceuticals in Subsurface Flow Constructed Wetlands: A Pilot-Scale Study. Environmental Science \& Technology 39(14), 5449-5454.

Matamoros, V., García, J. and Bayona, J.M. (2008) Organic micropollutant removal in a full-scale surface flow constructed wetland fed with secondary effluent. Water Research 42(3), 653-660.

Matamoros, V., Jover, E. and Bayona, J.M. (2010) Occurrence and fate of benzothiazoles and benzotriazoles in constructed wetlands. Water Science and Technology 61(1), 191-198.

Matamoros, V. and Salvadó, V. (2012) Evaluation of the seasonal performance of a water reclamation pondconstructed wetland system for removing emerging contaminants. Chemosphere 86(2), 111-117. 
Mazioti, A.A., Stasinakis, A.S., Pantazi, Y. and Andersen, H.R. (2015) Biodegradation of benzotriazoles and hydroxy-benzothiazole in wastewater by activated sludge and moving bed biofilm reactor systems. Bioresource Technology 192, 627-635.

Metcalf and Eddy (2003) Wastewater Engineering: Treatment, and Reuse, McGraw-Hill Companies, Inc., New York.

Metcalfe, C.D., Koenig, B.G., Bennie, D.T., Servos, M., Ternes, T.A. and Hirsch, R. (2003) Occurrence of neutral and acidic drugs in the effluents of Canadian sewage treatment plants. Environmental Toxicology and Chemistry 22(12), 2872-2880.

Meyer, J. and Bester, K. (2004) Organophosphate flame retardants and plasticisers in wastewater treatment plants. Journal of Environmental Monitoring 6(7), 599-605.

Michael, I., Rizzo, L., McArdell, C.S., Manaia, C.M., Merlin, C., Schwartz, T., Dagot, C. and Fatta-Kassinos, D. (2013) Urban wastewater treatment plants as hotspots for the release of antibiotics in the environment: A review. Water Research 47(3), 957-995.

Molinos-Senante, M., Reif, R., Garrido-Baserba, M., Hernández-Sancho, F., Omil, F., Poch, M. and SalaGarrido, R. (2013) Economic valuation of environmental benefits of removing pharmaceutical and personal care products from WWTP effluents by ozonation. Science of the Total Environment 461-462, 409-415.

Morris, S., Allchin, C.R., Zegers, B.N., Haftka, J.J., Boon, J.P., Belpaire, C., Leonards, P.E., Van Leeuwen, S.P. and De Boer, J. (2004) Distribution and fate of HBCD and TBBPA brominated flame retardants in North Sea estuaries and aquatic food webs. Environmental Science and Technology 38(21), 5497-5504.

Nakada, N., Tanishima, T., Shinohara, H., Kiri, K. and Takada, H. (2006) Pharmaceutical chemicals and endocrine disrupters in municipal wastewater in Tokyo and their removal during activated sludge treatment. Water Research 40(17), 3297-3303.

Naquin, A., Shrestha, A., Sherpa, M., Nathaniel, R. and Boopathy, R. (2015) Presence of antibiotic resistance genes in a sewage treatment plant in Thibodaux, Louisiana, USA. Bioresource Technology 188, 79-83. 
Nolvak, H., Truu, M., Tiirik, K., Oopkaup, K., Sildvee, T., Kaasik, A., Mander, U. and Truu, J. (2013) Dynamics of antibiotic resistance genes and their relationships with system treatment efficiency in a horizontal subsurface flow constructed wetland. Science of the Total Environment 461-462, 636-644.

NORMAN network (2017) NORMAN network - Glossary of Terms. http://www.normannetwork.net/?q=node/9 Accessed 20 June 2017.

Novo, A., André, S., Viana, P., Nunes, O.C. and Manaia, C.M. (2013) Antibiotic resistance, antimicrobial residues and bacterial community composition in urban wastewater. Water Research 47(5), 1875-1887.

Ojajuni, O., Saroj, D. and Cavalli, G. (2015) Removal of organic micropollutants using membrane-assisted processes: a review of recent progress. Environmental Technology Reviews 4(1), 17-37.

Omil, F., Suárez, S., Carballa, M., Reif, R. and Lema, J.M. (2010) Xenobiotics in the Urban Water Cycle: Mass Flows, Environmental Processes, Mitigation and Treatment Strategies. Fatta-Kassinos, D., Bester, K. and Kümmerer, K. (eds), pp. 283-306, Springer Netherlands, Dordrecht.

Onesios, K.M., Yu, J.T. and Bouwer, E.J. (2008) Biodegradation and removal of pharmaceuticals and personal care products in treatment systems: a review. Biodegradation 20(4), 441-466.

Oosterhuis, M., Sacher, F. and ter Laak, T.L. (2013) Prediction of concentration levels of metformin and other high consumption pharmaceuticals in wastewater and regional surface water based on sales data. Science of the Total Environment 442, 380-388.

Osinska, A., Korzeniewska, E., Harnisz, M. and Niestepski, S. (2017) The prevalence and characterization of antibiotic-resistant and virulent Escherichia coli strains in the municipal wastewater system and their environmental fate. Science of the Total Environment 577, 367-375.

Oulton, R.L., Kohn, T. and Cwiertny, D.M. (2010) Pharmaceuticals and personal care products in effluent matrices: A survey of transformation and removal during wastewater treatment and implications for wastewater management. Journal of Environmental Monitoring 12(11), 1956-1978.

Pan, C.-G., Liu, Y.-S. and Ying, G.-G. (2016) Perfluoroalkyl substances (PFASs) in wastewater treatment plants and drinking water treatment plants: Removal efficiency and exposure risk. Water Research 106, 562-570. 
Pan, Y., Shi, Y., Wang, J. and Cai, Y. (2011) Evaluation of perfluorinated compounds in seven wastewater treatment plants in Beijing urban areas. Science China Chemistry 54(3), 552-558.

Papageorgiou, M., Kosma, C. and Lambropoulou, D. (2016) Seasonal occurrence, removal, mass loading and environmental risk assessment of 55 pharmaceuticals and personal care products in a municipal wastewater treatment plant in Central Greece. Science of the Total Environment 543, 547-569.

Park, J., Yamashita, N., Park, C., Shimono, T., Takeuchi, D.M. and Tanaka, H. (2017) Removal characteristics of pharmaceuticals and personal care products: Comparison between membrane bioreactor and various biological treatment processes. Chemosphere 179, 347-358.

Pasquini, L., Munoz, J.-F., Pons, M.-N., Yvon, J., Dauchy, X., France, X., Le, N.D., France-Lanord, C. and Görner, T. (2014) Occurrence of eight household micropollutants in urban wastewater and their fate in a wastewater treatment plant. Statistical evaluation. Science of the Total Environment 481, 459-468.

Peñuelas, J., Poulter, B., Sardans, J., Ciais, P., van der Velde, M., Bopp, L., Boucher, O., Godderis, Y., Hinsinger, P., Llusia, J., Nardin, E., Vicca, S., Obersteiner, M. and Janssens, I.A. (2013) Human-induced nitrogen-phosphorus imbalances alter natural and managed ecosystems across the globe. Nature Communications 4, 2934.

Pérez, S. and Barceló, D. (2008) First Evidence for Occurrence of Hydroxylated Human Metabolites of Diclofenac and Aceclofenac in Wastewater Using QqLIT-MS and QqTOF-MS. Analytical Chemistry 80(21), 8135-8145.

Perez, S., Eichhorn, P. and Aga, D.S. (2005) Evaluating the biodegradability of sulfamethazine, sulfamethoxazole, sulfathiazole, and trimethoprim at different stages of sewage treatment. Environmental Toxicology and Chemistry 24(6), 1361-1367.

Peterson, E.W. and Lanning, A. (2009) Effectiveness of pilot-scale wetland designs in removing estrogenic compounds from municipal wastewater plant effluent Environmental Geosciences 16(2), 61-69.

Petrovic, M., de Alda, M.J.L., Diaz-Cruz, S., Postigo, C., Radjenovic, J., Gros, M. and Barcelo, D. (2009) Fate and removal of pharmaceuticals and illicit drugs in conventional and membrane bioreactor wastewater 
treatment plants and by riverbank filtration. Philosophical Transactions of the Royal Society of London A: Mathematical, Physical and Engineering Sciences 367(1904), 3979-4003.

Phan, H.V., Hai, F.I., Kang, J., Dam, H.K., Zhang, R., Price, W.E., Broeckmann, A. and Nghiem, L.D. (2014) Simultaneous nitrification/denitrification and trace organic contaminant (TrOC) removal by an anoxicaerobic membrane bioreactor (MBR). Bioresource Technology 165, 96-104.

Phan, H.V., Hai, F.I., McDonald, J.A., Khan, S.J., Zhang, R., Price, W.E., Broeckmann, A. and Nghiem, L.D. (2015) Nutrient and trace organic contaminant removal from wastewater of a resort town: Comparison between a pilot and a full scale membrane bioreactor. International Biodeterioration \& Biodegradation 102, 40-48.

Piña, B., Bayona, J.M., Christou, A., Fatta-Kassinos, D., Guillon, E., Lambropoulou, D., Michael, C., Polesel, F. and Sayen, S. (2018) On the contribution of reclaimed wastewater irrigation to the potential exposure of humans to antibiotics, antibiotic resistant bacteria and antibiotic resistance genes - NEREUS COST Action ES1403 position paper. Journal of Environmental Chemical Engineering.

Polesel, F., Andersen, H.R., Trapp, S. and Plósz, B.G. (2016) Removal of Antibiotics in Biological Wastewater Treatment Systems-A Critical Assessment Using the Activated Sludge Modeling Framework for Xenobiotics (ASM-X). Environmental Science \& Technology 50(19), 10316-10334.

Potvin, C.M., Long, Z. and Zhou, H. (2012) Removal of tetrabromobisphenol A by conventional activated sludge, submerged membrane and membrane aerated biofilm reactors. Chemosphere 89(10), 1183-1188. Pruden, A., Edwards, M. and Falkinham, J.O. (2013) State of the Science of opportunistic pathogens in premise plumbing: methodology, microbial ecology, and epidemiology.

Qi, W., Singer, H., Berg, M., Müller, B., Pernet-Coudrier, B., Liu, H. and Qu, J. (2015) Elimination of polar micropollutants and anthropogenic markers by wastewater treatment in Beijing, China. Chemosphere 119, 1054-1061.

Qiang, Z., Dong, H., Zhu, B., Qu, J. and Nie, Y. (2013) A comparison of various rural wastewater treatment processes for the removal of endocrine-disrupting chemicals (EDCs). Chemosphere 92(8), 986-992. 
Quintana, J.B., Weiss, S. and Reemtsma, T. (2005) Pathways and metabolites of microbial degradation of selected acidic pharmaceutical and their occurrence in municipal wastewater treated by a membrane bioreactor. Water Research 39(12), 2654-2664.

Radjenović, J., Matošić, M., Mijatović, I., Petrović, M. and Barceló, D. (2008) Emerging Contaminants from Industrial and Municipal Waste: Removal Technologies. Barceló, D. and Petrovic, M. (eds), pp. 37-101, Springer Berlin Heidelberg, Berlin, Heidelberg.

Radjenovic, J., Petrovic, M. and Barceló, D. (2007) Analysis of pharmaceuticals in wastewater and removal using a membrane bioreactor. Analytical and Bioanalytical Chemistry 387(4), 1365-1377.

Radjenovic, J., Petrovic, M. and Barceló, D. (2009) Fate and distribution of pharmaceuticals in wastewater and sewage sludge of the conventional activated sludge (CAS) and advanced membrane bioreactor (MBR) treatment. Water Research 43, 831-841.

Rafraf, I.D., Lekunberri, I., Sanchez-Melsio, A., Aouni, M., Borrego, C.M. and Balcazar, J.L. (2016) Abundance of antibiotic resistance genes in five municipal wastewater treatment plants in the Monastir Governorate, Tunisia. Environmental Pollution 219, 353-358.

Reemtsma, T., Miehe, U., Duennbier, U. and Jekel, M. (2010) Polar pollutants in municipal wastewater and the water cycle: Occurrence and removal of benzotriazoles. Water Research 44(2), 596-604.

Reif, R., Omil, F. and Lema, J.M. (2013) Comprehensive Analytical Chemistry. Mira Petrovic, D.B. and Sandra, P. (eds), pp. 287-317, Elsevier.

Reyes-Contreras, C., Hijosa-Valsero, M., Sidrach-Cardona, R., Bayona, J.M. and Bécares, E. (2012) Temporal evolution in PPCP removal from urban wastewater by constructed wetlands of different configuration: A medium-term study. Chemosphere 88(2), 161-167.

Reyes-Contreras, C., Matamoros, V., Ruiz, I., Soto, M. and Bayona, J.M. (2011) Evaluation of PPCPs removal in a combined anaerobic digester-constructed wetland pilot plant treating urban wastewater. Chemosphere 84(9), 1200-1207. 
Rivera-Utrilla, J., Sánchez-Polo, M., Ferro-García, M.Á., Prados-Joya, G. and Ocampo-Pérez, R. (2013) Pharmaceuticals as emerging contaminants and their removal from water. A review. Chemosphere 93(7), 1268-1287.

Rizzo, L., Manaia, C., Merlin, C., Schwartz, T., Dagot, C., Ploy, M.C., Michael, I. and Fatta-Kassinos, D. (2013) Urban wastewater treatment plants as hotspots for antibiotic resistant bacteria and genes spread into the environment: A review. Science of the Total Environment 447, 345-360.

Rodriguez-Mozaz, S., Chamorro, S., Marti, E., Huerta, B., Gros, M., Sànchez-Melsió, A., Borrego, C.M., Barceló, D. and Balcázar, J.L. (2015) Occurrence of antibiotics and antibiotic resistance genes in hospital and urban wastewaters and their impact on the receiving river. Water Research 69, 234-242.

Rodriguez-Narvaez, O.M., Peralta-Hernandez, J.M., Goonetilleke, A. and Bandala, E.R. (2017) Treatment technologies for emerging contaminants in water: A review. Chemical Engineering Journal 323, 361-380.

Rojas, M.R., Leung, C., Bonk, F., Zhu, Y., Edwards, L., Arnold, R.G., Sáez, A.E. and Klečka, G. (2013) Assessment of the Effectiveness of Secondary Wastewater Treatment Technologies to Remove Trace Chemicals of Emerging Concern. Critical Reviews in Environmental Science and Technology 43(12), 1281-1314.

Rousseau, D.P.L., Lesage, E., Story, A., Vanrolleghem, P.A. and De Pauw, N. (2008) Constructed wetlands for water reclamation. Desalination 218(1), 181-189.

Ryu, J., Oh, J., Snyder, S.A. and Yoon, Y. (2014) Determination of micropollutants in combined sewer overflows and their removal in a wastewater treatment plant (Seoul, South Korea). Environmental Monitoring and Assessment 186, 12.

Sadaria, A.M., Supowit, S.D. and Halden, R.U. (2016) Mass Balance Assessment for Six Neonicotinoid Insecticides During Conventional Wastewater and Wetland Treatment: Nationwide Reconnaissance in United States Wastewater. Environmental Science and Technology 50(12), 6199-6206.

Sahar, E., David, I., Gelman, Y., Chikurel, H., Aharoni, A., Messalem, R. and Brenner, A. (2011a) The use of RO to remove emerging micropollutants following CAS/UF or MBR treatment of municipal wastewater. Desalination 273(1), 142-147. 
Sahar, E., Ernst, M., Godehardt, M., Hein, A., Herr, J., Kazner, C., Melin, T., Cikurel, H., Aharoni, A., Messalem, R., Brenner, A. and Jekel, M. (2011b) Comparison of two treatments for the removal of selected organic micropollutants and bulk organic matter: conventional activated sludge followed by ultrafiltration versus membrane bioreactor. Water Science and Technology 63(4), 733-740.

Sahar, E., Messalem, R., Cikurel, H., Aharoni, A., Brenner, A., Godehardt, M., Jekel, M. and Ernst, M. (2011c) Fate of antibiotics in activated sludge followed by ultrafiltration (CAS-UF) and in a membrane bioreactor (MBR). Water Research 45(16), 4827-4836.

Salt, D., Smith, R. and Raskin, I. (1998) Phytoremediation. Annual Review of Plant Physiology and Plant Molecular Biology 49, 643-668.

Sari, S., Ozdemir, G., Yangin-Gomec, C., Zengin, G.E., Topuz, E., Aydin, E., Pehlivanoglu-Mantas, E. and Tas, D.O. (2014) Seasonal variation of diclofenac concentration and its relation with wastewater characteristics at two municipal wastewater treatment plants in Turkey. Journal of Hazardous materials 272, 155-164.

Schröder, H.F., Tambosi, J.L., Sena, R.F., Moreira, R.F.P.M., José, H.J. and Pinnekamp, J. (2012) The removal and degradation of pharmaceutical compounds during membrane bioreactor treatment. Water Science and Technology 65(5), 833-839.

Schröder, P., Helmreich, B., Škrbić, B., Carballa, M., Papa, M., Pastore, C., Emre, Z., Oehmen, A., Langenhoff, A., Molinos, M., Dvarioniene, J., Huber, C., Tsagarakis, K.P., Martinez-Lopez, E., Pagano, S.M., Vogelsang, C. and Mascolo, G. (2016) Status of hormones and painkillers in wastewater effluents across several European states - considerations for the EU watch list concerning estradiols and diclofenac. Environmental Science and Pollution Research 23(13), 12835-12866.

Segura, P.A., Francois, M., Gagnon, C. and Sauve, S. (2009) Review of the occurrence of anti-infectives in contaminated wastewaters and natural and drinking waters. Environmental Health Perspectives 117(5), 675684.

Segura, P.A., MacLeod, S.L., Lemoine, P., Sauve, S. and Gagnon, C. (2011) Quantification of carbamazepine and atrazine and screening of suspect organic contaminants in surface and drinking waters. Chemosphere 84(8), 1085-1094. 
Senta, I., Terzic, S. and Ahel, M. (2013) Occurrence and fate of dissolved and particulate antimicrobials in municipal wastewater treatment. Water Research 47(2), 705-714.

Sharma, V.K., Johnson, N., Cizmas, L., McDonald, T.J. and Kim, H. (2016) A review of the influence of treatment strategies on antibiotic resistant bacteria and antibiotic resistance genes. Chemosphere 150, 702714.

Shojaee Nasirabadi, P., Saljoughi, E. and Mousavi, S.M. (2016) Membrane processes used for removal of pharmaceuticals, hormones, endocrine disruptors and their metabolites from wastewaters: a review. Desalination and Water Treatment 57(51), 24146-24175.

Sidrach-Cardona, R. and Bécares, E. (2013) Fecal indicator bacteria resistance to antibiotics in experimental constructed wetlands. Ecological Engineering 50, 107-111.

Siegrist, H. and Joss, A. (2012) Review on the fate of organic micropollutants in wastewater treatment and water reuse with membranes. Water Science and Technology 66(6), 1369-1376.

Singer, H., Muller, S., Tixier, C. and Pillonel, L. (2002) Triclosan: occurrence and fate of a widely used biocide in the aquatic environment: field measurements in wastewater treatment plants, surface waters, and lake sediments. Environmental Science and Technology 36(23), 4998-5004.

Sipma, J., Osuna, B., Collado, N., Monclús, H., Ferrero, G., Comas, J. and Rodriguez-Roda, I. (2010) Comparison of removal of pharmaceuticals in MBR and activated sludge systems. Desalination 250(2), 653659.

Snyder, S.A., Adham, S., Redding, A.M., Cannon, F.S., DeCarolis, J., Oppenheimer, J., Wert, E.C. and Yoon, Y. (2007) Role of membranes and activated carbon in the removal of endocrine disruptors and pharmaceuticals. Desalination 202(1-3), 156-181.

Stephenson, R. and Oppenheimer, J. (2007) Fate of Pharmaceuticals and Personal Care Products through Municipal Wastewater Treatment Processes.

Strenn, B., Clara, M., Gans, O. and Kreuzinger, N. (2004) Carbamazepine, diclofenac, ibuprofen and bezafibrate - investigations on the behaviour of selected pharmaceuticals during wastewater treatment. Water Science and Technology 50(5), 269-276. 
Su, H.C., Ying, G.G., He, L.Y., Liu, Y.S., Zhang, R.Q. and Tao, R. (2014) Antibiotic resistance, plasmid-mediated quinolone resistance (PMQR) genes and ampC gene in two typical municipal wastewater treatment plants. Environ Sci Process Impacts 16(2), 324-332.

Suarez, S., Lema, J.M. and Omil, F. (2010) Removal of Pharmaceutical and Personal Care Products (PPCPs) under nitrifying and denitrifying conditions. Water Research 44(10), 3214-3224.

Sui, Q., Huang, J., Deng, S., Chen, W. and Yu, G. (2011) Seasonal Variation in the Occurrence and Removal of Pharmaceuticals and Personal Care Products in Different Biological Wastewater Treatment Processes. Environmental Science \& Technology 45(8), 3341-3348.

Sun, Y., Shen, Y.X., Liang, P., Zhou, J., Yang, Y. and Huang, X. (2016) Multiple antibiotic resistance genes distribution in ten large-scale membrane bioreactors for municipal wastewater treatment. Bioresource Technology 222, 100-106.

Taheran, M., Brar, S.K., Verma, M., Surampalli, R.Y., Zhang, T.C. and Valero, J.R. (2016) Membrane processes for removal of pharmaceutically active compounds (PhACs) from water and wastewaters. Science of the Total Environment 547, 60-77.

Talib, A. and Randhir, T.O. (2017) Managing emerging contaminants in watersheds: Need for comprehensive, systems-based strategies. Sustainability of Water Quality and Ecology 9-10, 1-8.

Tambosi, J.L., de Sena, R.F., Favier, M., Gebhardt, W., José, H.J., Schröder, H.F. and Moreira, R.d.F.P.M. (2010a) Removal of pharmaceutical compounds in membrane bioreactors (MBR) applying submerged membranes. Desalination 261(1-2), 148-156.

Tambosi, J.L., Yamanaka, L.Y., José, H.J., Moreira, R.d.F.P.M. and Schröder, H.F. (2010b) Recent research data on the removal of pharmaceuticals from sewage treatment plants (STP). Quimica Nova 33, 411-420.

Tang, K., Ooi, G.T.H., Litty, K., Sundmark, K., Kaarsholm, K.M.S., Sund, C., Kragelund, C., Christensson, M., Bester, K. and Andersen, H.R. (2017) Removal of pharmaceuticals in conventionally treated wastewater by a polishing moving bed biofilm reactor (MBBR) with intermittent feeding. Bioresource Technology 236, 77-86. 
Tiedeken, E.J., Tahar, A., McHugh, B. and Rowan, N.J. (2017) Monitoring, sources, receptors, and control measures for three European Union watch list substances of emerging concern in receiving waters - A 20 year systematic review. Science of the Total Environment 574, 1140-1163.

Tiwari, B., Sellamuthu, B., Ouarda, Y., Drogui, P., Tyagi, R.D. and Buelna, G. (2017) Review on fate and mechanism of removal of pharmaceutical pollutants from wastewater using biological approach. Bioresource Technology 224, 1-12.

Torresi, E., Escola Casas, M., Polesel, F., Plosz, B.G., Christensson, M. and Bester, K. (2017) Impact of external carbon dose on the removal of micropollutants using methanol and ethanol in post-denitrifying Moving Bed Biofilm Reactors. Water Research 108, 95-105.

Tran, N.H., Chen, H., Reinhard, M., Mao, F. and Gin, K.Y.-H. (2016) Occurrence and removal of multiple classes of antibiotics and antimicrobial agents in biological wastewater treatment processes. Water Research $104,461-472$.

Tran, N.H. and Gin, K.Y.-H. (2017) Occurrence and removal of pharmaceuticals, hormones, personal care products, and endocrine disrupters in a full-scale water reclamation plant. Science of the Total Environment 599-600, 1503-1516.

Tran, N.H., Reinhard, M. and Gin, K.Y.-H. (2018) Occurrence and fate of emerging contaminants in municipal wastewater treatment plants from different geographical regions-a review. Water Research 133, 182-207. Tran, N.H., Urase, T., Ngo, H.H., Hu, J. and Ong, S.L. (2013) Insight into metabolic and cometabolic activities of autotrophic and heterotrophic microorganisms in the biodegradation of emerging trace organic contaminants. Bioresource Technology 146, 721-731.

Trinh, T., Coleman, H.M., Stuetz, R.M., Drewes, J.E., Le-Clech, P. and Khan, S.J. (2016a) Hazardous events in membrane bioreactors - Part 2: Impacts on removal of trace organic chemical contaminants. Journal of Membrane Science 497, 504-513.

Trinh, T., van den Akker, B., Coleman, H.M., Stuetz, R.M., Drewes, J.E., Le-Clech, P. and Khan, S.J. (2016b) Seasonal variations in fate and removal of trace organic chemical contaminants while operating a full-scale membrane bioreactor. Science of the Total Environment 550, 176-183. 
Trinh, T., van den Akker, B., Coleman, H.M., Stuetz, R.M., Le-Clech, P. and Khan, S.J. (2012a) Removal of endocrine disrupting chemicals and microbial indicators by a decentralised membrane bioreactor for water reuse. Journal of Water Reuse and Desalination 2(2), 67-73.

Trinh, T., van den Akker, B., Stuetz, R.M., Coleman, H.M., Le-Clech, P. and Khan, S.J. (2012b) Removal of trace organic chemical contaminants by a membrane bioreactor. Water Science and Technology 66(9), 1856-1863. Tsui, M.M., Leung, H.W., Lam, P.K. and Murphy, M.B. (2014) Seasonal occurrence, removal efficiencies and preliminary risk assessment of multiple classes of organic UV filters in wastewater treatment plants. Water Research 53, 58-67.

Verlicchi, P., Al Aukidy, M. and Zambello, E. (2012) Occurrence of pharmaceutical compounds in urban wastewater: Removal, mass load and environmental risk after a secondary treatment-A review. Science of the Total Environment 429, 123-155.

Verlicchi, P. and Zambello, E. (2014) How efficient are constructed wetlands in removing pharmaceuticals from untreated and treated urban wastewaters? A review. Science of the Total Environment 470-471, 12811306.

Vidal-Dorsch, D.E., Bay, S.M., Maruya, K., Snyder, S.A., Trenholm, R.A. and Vanderford, B.J. (2012) Contaminants of emerging concern in municipal wastewater effluents and marine receiving water. Environmental Toxicology and Chemistry 31(12), 2674-2682.

Vieno, N. and Sillanpää, M. (2014) Fate of diclofenac in municipal wastewater treatment plant - A review. Environment International 69(0), 28-39.

Vieno, N. and Toivikko, S. (2014) The occurrence of environmentally relevant hazardous substances in Finnish wastewater treatment plants. IWA World Water Conference and Exhibition, Lisbon.

Vieno, N.M., Tuhkanen, T. and Kronberg, L. (2005) Seasonal Variation in the Occurrence of Pharmaceuticals in Effluents from a Sewage Treatment Plant and in the Recipient Water. Environmental Science \& Technology 39(21), 8220-8226.

Vymazal, J. (2011a) Constructed wetlands for wastewater treatment: five decades of experience. Environ Sci Technol. 45(1), 61-69. 
Vymazal, J. (2011b) Water and Nutrient Management in Natural and Constructed Wetlands, Springer.

Vymazal, J. and Březinová, T. (2015) Heavy metals in plants in constructed and natural wetlands: concentration, accumulation and seasonality. Water Science and Technology 71(2), 268-276.

Vymazal, J., Dvořáková Březinová, T., Koželuh, M. and Kule, L. (2017) Occurrence and removal of pharmaceuticals in four full-scale constructed wetlands in the Czech Republic - the first year of monitoring. Ecological Engineering 98, 354-364.

Wang L., L.Y., Shang X., Shen J. (2014) Occurrence and removal of N-nitrosodimethylamine and its precursors in wastewater treatment plants in and around Shanghai. Frontiers of Environmental Science \& Engineering 8 (4), 519-530.

Watkinson, A.J., Murby, E.J. and Costanzo, S.D. (2007) Removal of antibiotics in conventional and advanced wastewater treatment: Implications for environmental discharge and wastewater recycling. Water Research 41(18), 4164-4176.

Weiss, S. and Reemtsma, T. (2008) Membrane bioreactors for municipal wastewater treatment - A viable option to reduce the amount of polar pollutants discharged into surface waters? Water Research 42(14), $3837-3847$.

Wen, Q., Yang, L., Duan, R. and Chen, Z. (2016) Monitoring and evaluation of antibiotic resistance genes in four municipal wastewater treatment plants in Harbin, Northeast China. Environmental Pollution 212, 34-40. Wijekoon, K.C., Hai, F.I., Kang, J., Price, W.E., Guo, W., Ngo, H.H. and Nghiem, L.D. (2013) The fate of pharmaceuticals, steroid hormones, phytoestrogens, UV-filters and pesticides during MBR treatment. Bioresource Technology 144(0), 247-254.

Wu, C., Xue, W., Zhou, H., Huang, X. and Wen, X. (2011a) Removal of endocrine disrupting chemicals in a large scale membrane bioreactor plant combined with anaerobic-anoxic-oxic process for municipal wastewater reclamation. Water Science and Technology 64(7), 1511-1518.

Wu, J., Huang, X., Li, H., Wei, C. and Wang, J. (2011b) Seasonal variation of activated sludge mixed liquors in a long-term steadily-operating membrane bioreactor. 6th IWA Specialist Conference on Membrane Technology for Water \& Wastewater Treatment, Aachen, Germany. 
Wu, S., Carvalho, P.N., Muller, J.A., Manoj, V.R. and Dong, R. (2016) Sanitation in constructed wetlands: A review on the removal of human pathogens and fecal indicators. Science of the Total Environment 541, 8-22. Xu, J., Xu, Y., Wang, H., Guo, C., Qiu, H., He, Y., Zhang, Y., Li, X. and Meng, W. (2015) Occurrence of antibiotics and antibiotic resistance genes in a sewage treatment plant and its effluent-receiving river. Chemosphere $119,1379-1385$.

Xue, W., Wu, C., Xiao, K., Huang, X., Zhou, H., Tsuno, H. and Tanaka, H. (2010) Elimination and fate of selected micro-organic pollutants in a full-scale anaerobic/anoxic/aerobic process combined with membrane bioreactor for municipal wastewater reclamation. Water Research 44(20), 5999-6010.

Yang, S. and Carlson, K.H. (2004) Solid-phase extraction-high-performance liquid chromatography-ion trap mass spectrometry for analysis of trace concentrations of macrolide antibiotics in natural and waste water matrices. Journal of Chromatography A 1038(1-2), 141-155.

Yang, X., Flowers, R.C., Weinberg, H.S. and Singer, P.C. (2011) Occurrence and removal of pharmaceuticals and personal care products (PPCPs) in an advanced wastewater reclamation plant. Water Research 45(16), $5218-5228$

Yang, Y., Li, B., Zou, S., Fang, H.H. and Zhang, T. (2014) Fate of antibiotic resistance genes in sewage treatment plant revealed by metagenomic approach. Water Research 62, 97-106.

Yang, Y., Ok, Y.S., Kim, K.-H., Kwon, E.E. and Tsang, Y.F. (2017) Occurrences and removal of pharmaceuticals and personal care products (PPCPs) in drinking water and water/sewage treatment plants: A review. Science of the Total Environment 596-597, 303-320.

Ying, G.G. and Kookana, R.S. (2007) Triclosan in wastewaters and biosolids from Australian wastewater treatment plants. Environment International 33(2), 199-205.

Yoon, S., Nakada, N. and Tanaka, H. (2011) Occurrence and removal of NDMA and NDMA formation potential in wastewater treatment plants. Journal of Hazardous materials 190(1-3), 897-902.

Zanotto, C., Bissa, M., Illiano, E., Mezzanotte, V., Marazzi, F., Turolla, A., Antonelli, M., De Giuli Morghen, C. and Radaelli, A. (2016) Identification of antibiotic-resistant Escherichia coli isolated from a municipal wastewater treatment plant. Chemosphere 164, 627-633. 
Zeng, X., Liu, Z., He, L., Cao, S., Song, H., Yu, Z., Sheng, G. and Fu, J. (2015) The occurrence and removal of organophosphate ester flame retardants/plasticizers in a municipal wastewater treatment plant in the Pearl River Delta, China. Journal of Environmental Science and Health, Part A 50, 7.

Zhang, C., Yan, H., Li, F. and Zhou, Q. (2015a) Occurrence and fate of perfluorinated acids in two wastewater treatment plants in Shanghai, China. Environ Sci Pollut Res Int 22(3), 1804-1811.

Zhang, D., Gersberg, R.M., Ng, W.J. and Tan, S.K. (2014) Removal of pharmaceuticals and personal care products in aquatic plant-based systems: A review. Environmental Pollution 184, 620-639.

Zhang, S., Han, B., Gu, J., Wang, C., Wang, P., Ma, Y., Cao, J. and He, Z. (2015b) Fate of antibiotic resistant cultivable heterotrophic bacteria and antibiotic resistance genes in wastewater treatment processes. Chemosphere 135, 138-145.

Zhang, W., Zhang, Y.T., Taniyasu, S., Yeung, L.W.Y., Lam, P.K.S., Wang, J.S., Li, X.H., Yamashita, N. and Dai, J.Y. (2013) Distribution and fate of perfluoroalkyl substances in municipal wastewater treatment plants in economically developed areas of China. Environmental Pollution 176, 10-17.

Zhou, L.J., Ying, G.G., Liu, S., Zhao, J.L., Yang, B., Chen, Z.F. and Lai, H.J. (2013) Occurrence and fate of eleven classes of antibiotics in two typical wastewater treatment plants in South China. Science of the Total Environment 452, 365-376.

Zhou, Y., Zha, J. and Wang, Z. (2012) Occurrence and fate of steroid estrogens in the largest wastewater treatment plant in Beijing, China. Environmental Monitoring and Assessment 184(11), 6799-6813.

Zonja, B., Perez, S. and Barcelo, D. (2016) Human Metabolite Lamotrigine-N(2)-glucuronide Is the Principal Source of Lamotrigine-Derived Compounds in Wastewater Treatment Plants and Surface Water. Environmental Science and Technology 50(1), 154-164.

Zuehlke, S., Duennbier, U., Lesjean, B., Gnirss, R. and Buisson, H. (2006) Long-Term Comparison of Trace Organics Removal Performances Between Conventional and Membrane Activated Sludge Processes. Water Environment Research 78(13), 2480-2486. 
Zupanc, M., Kosjek, T., Petkovsek, M., Dular, M., Kompare, B., Sirok, B., Blazeka, Z. and Heath, E. (2013) Removal of pharmaceuticals from wastewater by biological processes, hydrodynamic cavitation and UV treatment. Ultrasonics Sonochemistry 20(4), 1104-1112. 


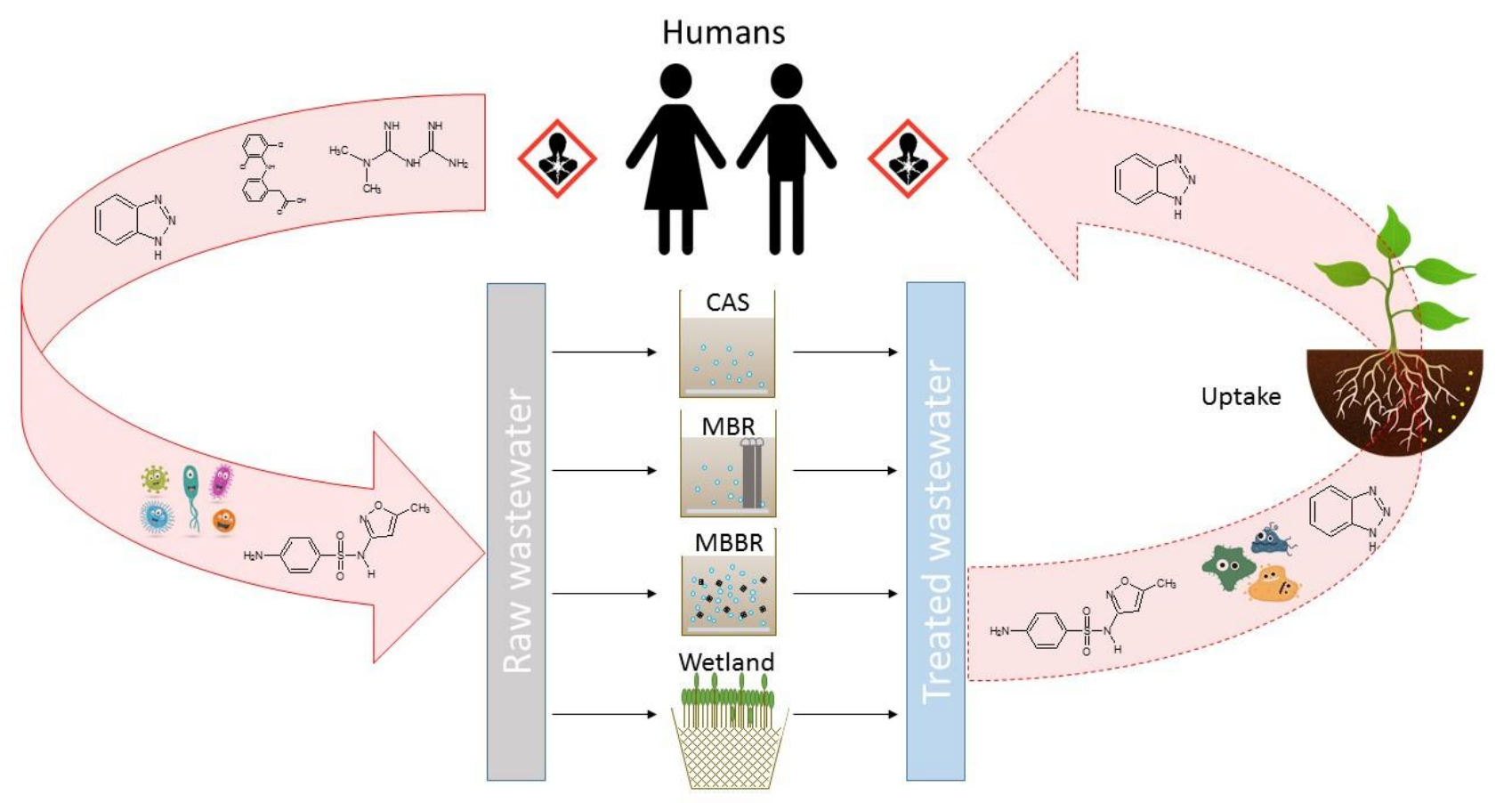

Graphical abstract 


\section{Highlights}

Fate of CEC relevant for crop uptake during secondary treatment was analysed.

Target CEC selection resulted from the indications of the NEREUS COST Action.

Effects of secondary treatment on microbial CEC (ARBs and ARGs) fate were described.

Most applied and promising technologies for urban wastewater treatment were compared.

Impact of CEC removal on WWTP upgrading, design and operation was discussed. 